In cooperation with the International Boundary and Water Commission; National Park Service; Texas Commission on Environmental Quality; Secretaría de Medio Ambiente y Recursos Naturales, Mexico; Área de Protección de Flora y Fauna Cañón de Santa Elena, Mexico; and Área de Protección de Flora y Fauna Maderas del Carmen, Mexico

\title{
Quality of Water and Sediment in Streams Affected by Historical Mining, and Quality of Mine Tailings, in the Rio Grande/Río Bravo Basin, Big Bend Area of the United States and Mexico, August 2002
}

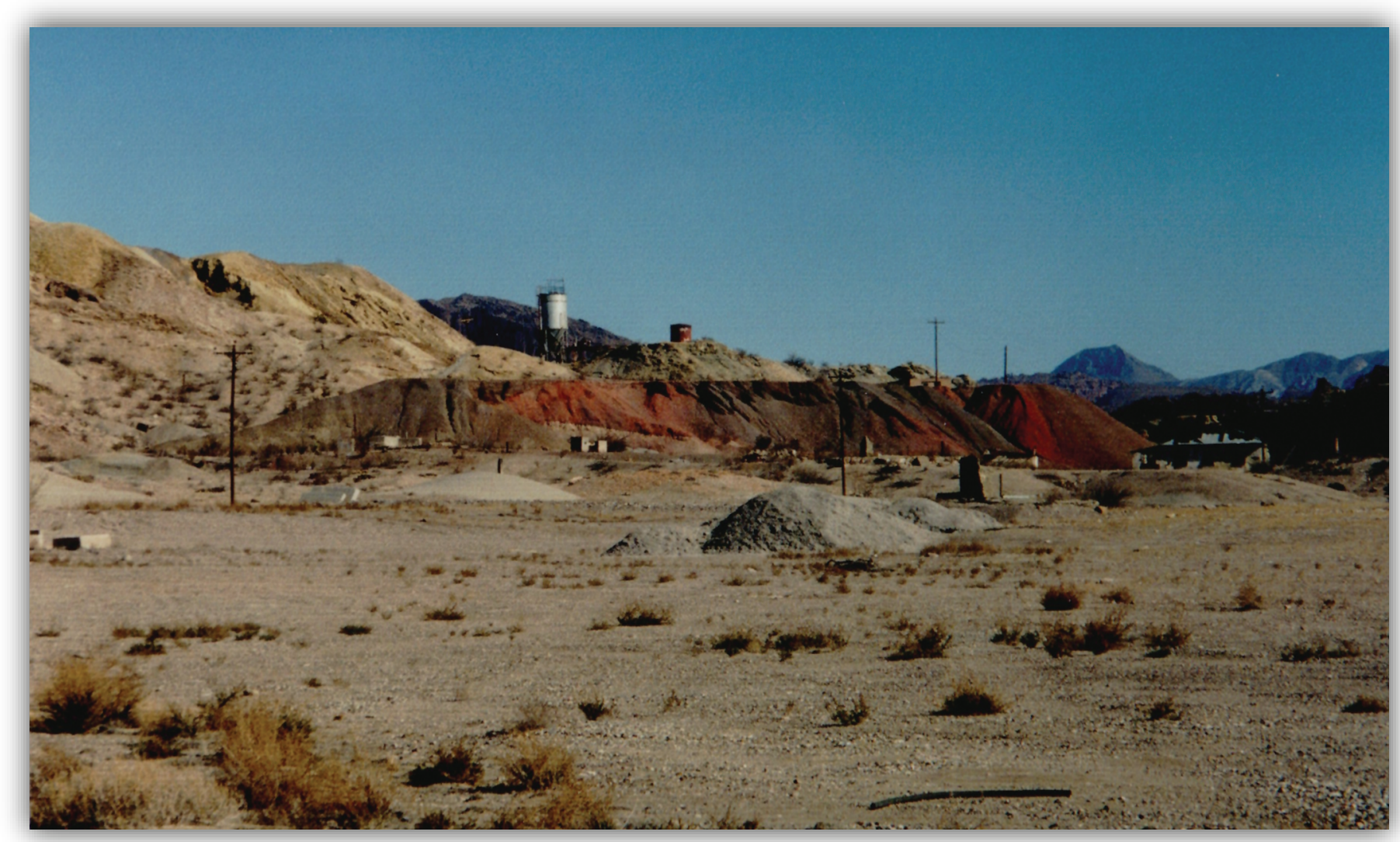

Scientific Investigations Report 2008-5032 
Front cover: Mine tailings piles in front of Study Butte Mine in Rough Run Draw near Study Butte, Texas, February 2002.

\section{Back cover:}

Top, Ted Small, U.S. Geological Survey hydrologist (1923-2007), on top of bluff at La Clocha primitive campground sample site, Big Bend National Park, Texas, August 2002.

Lower left, U.S. Geological Survey hydrologic technician collecting water-quality sample from Rio Grande/Río Bravo, August 2002.

Lower right, Mine processing debris and tailings from mercury retort furnaces in Terlingua Creek watershed near Terlingua, Texas, February 2002. 


\section{Quality of Water and Sediment in Streams Affected by Historical Mining, and Quality of Mine Tailings, in the Rio Grande/ Río Bravo Basin, Big Bend Area of the United States and Mexico, August 2002}

By Rebecca B. Lambert, Christine M. Kolbe, and Wayne Belzer

In cooperation with the International Boundary and Water Commission; National Park Service; Texas Commission on Environmental Quality; Secretaría de Medio Ambiente y Recursos Naturales, Mexico; Área de Protección de Flora y Fauna Cañón de Santa Elena, Mexico; and Área de Protección de Flora y Fauna Maderas del Carmen, Mexico

Scientific Investigations 2008-5032 


\section{U.S. Department of the Interior DIRK KEMPTHORNE, Secretary}

\section{U.S. Geological Survey \\ Mark D. Myers, Director}

\section{U.S. Geological Survey, Reston, Virginia: 2008}

For product and ordering information:

World Wide Web: http://www.usgs.gov/pubprod

Telephone: 1-888-ASK-USGS

For more information on the USGS — the Federal source for science about the Earth, its natural and living resources, natural hazards, and the environment:

World Wide Web: http://www.usgs.gov

Telephone: 1-888-ASK-USGS

Any use of trade, product, or firm names is for descriptive purposes only and does not imply endorsement by the U.S. Government.

Although this report is in the public domain, permission must be secured from the individual copyright owners to reproduce any copyrighted materials contained within this report.

Suggested citation:

Lambert, R.B., Kolbe, C.M., and Belzer, Wayne, 2008, Quality of water and sediment in streams affected by historical mining, and quality of mine tailings, in the Rio Grande/Río Bravo Basin, Big Bend area of the United States and Mexico: U.S. Geological Survey Scientific Investigations Report 2008-5032, 45 p. 


\section{Contents}

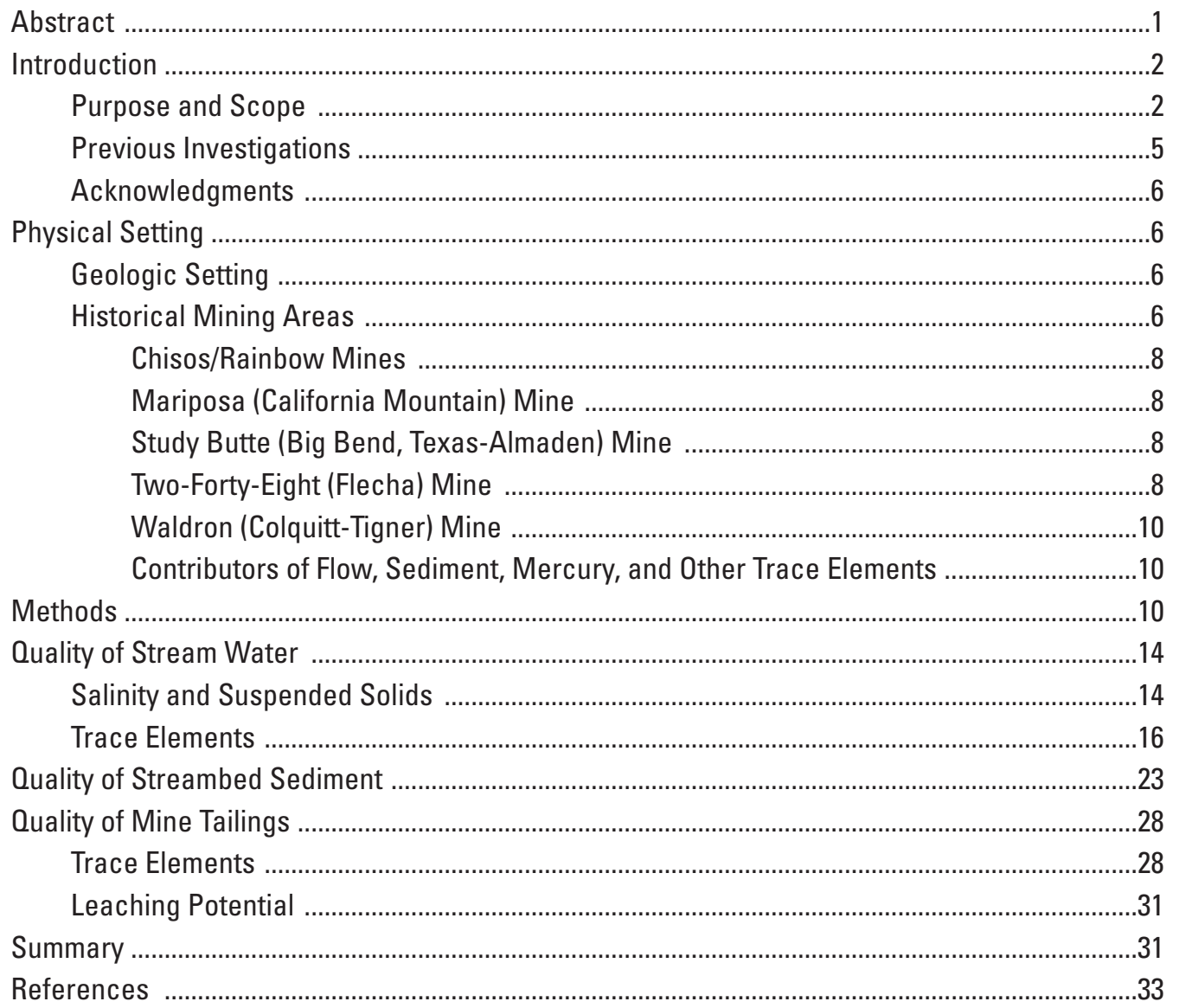

\section{Figures}

1-2. Maps showing:

1. Regional parks and protected areas in the Big Bend area of the United States and Mexico (study area)

2. Locations of sites sampled August 2002 in the Big Bend area of Texas, United States, and Chihuahua and Coahuila, Mexico

3. Photographs showing examples of mine and mine-tailing sample sites at (A) Study Butte Mine, (B) Chisos Mine, (C) Mariscal Mine, (D) La Linda Mine/ processing plant, (E) La Esperanza (San Carlos) Mine, and (F) Boquillas Mine (tailings)

4. Boxplots showing distribution of concentrations of calcium, sulfate, chloride, dissolved solids, total suspended solids, and volatile suspended solids in water samples collected August 6-9, 2002, in the Big Bend area of the United States and Mexico 
5-6. Graphs showing:

5. Concentrations of calcium, sulfate, and chloride in water samples collected August 6-9, 2002, from Rio Grande/Río Bravo main-stem (MS) and tributary (TR) sites (downstream order) in the Big Bend area of the United States and Mexico

6. Concentrations of dissolved solids, total suspended solids, and volatile suspended solids in water samples collected August 6-9, 2002, from Rio Grande/Río Bravo main-stem (MS) and tributary (TR) sites (downstream order) in the Big Bend area of the United States and Mexico

7. Boxplots showing distribution of concentrations of aluminum, barium, copper, mercury, nickel, selenium, and zinc in water samples collected August 6-9, 2002, in the Big Bend area of the United States and Mexico

8-12. Graphs showing:

8. Concentrations of aluminum and barium in water samples collected August 6-9, 2002, from Rio Grande/Río Bravo main-stem (MS) and tributary (TR) sites (downstream order) in the Big Bend area of the United States and Mexico

9. Concentrations of copper and nickel in water samples collected August 6-9, 2002, from Rio Grande/Río Bravo main-stem (MS) and tributary (TR) sites (downstream order) in the Big Bend area of the United States and Mexico .20

10. Concentration of mercury in water samples collected August 6-9, 2002, from Rio Grande/Río Bravo main-stem (MS) and tributary (TR) sites (downstream order) in the Big Bend area of the United States and Mexico .21

11. Relation of concentrations of total recoverable mercury to total suspended solids for water samples collected August 6-9, 2002, from Rio Grande/Río Bravo main-stem and tributary sites in the Big Bend area of the United States and Mexico

12. Concentrations of selenium and zinc in water samples collected August 6-9, 2002, from Rio Grande/Río Bravo main-stem (MS) and tributary (TR) sites (downstream order) in the Big Bend area of the United States and Mexico .........23

13. Boxplots showing distribution of concentrations of antimony, arsenic, beryllium, cadmium, and chromium in streambed-sediment samples collected August 6-9, 2002, in the Big Bend area of the United States and Mexico

14-15. Graphs showing:

14. Concentrations of antimony and arsenic in streambed-sediment samples collected August 6-9, 2002, from Rio Grande/Río Bravo main-stem (MS) and tributary (TR) sites (downstream order) in the Big Bend area of the United States and Mexico

15. Concentrations of beryllium, cadmium, and chromium in streambed-sediment samples collected August 6-9, 2002, from Rio Grande/Río Bravo main-stem (MS) and tributary (TR) sites (downstream order) in the Big Bend area of the United States and Mexico

16. Boxplots showing distribution of concentrations of copper, mercury, and nickel in streambed-sediment samples collected August 6-9, 2002, in the Big Bend area of the United States and Mexico

17. Graph showing concentrations of copper, mercury, and nickel in streambedsediment samples collected August 6-9, 2002, from Rio Grande/Río Bravo main-stem (MS) and tributary (TR) sites (downstream order) in the Big Bend area of the United States and Mexico 
18. Boxplots showing distribution of concentrations of lead, manganese, and zinc in streambed-sediment samples collected August 6-9, 2002, from Rio Grande/Río Bravo main-stem and tributary sites in the Big Bend area of the United States and Mexico

19-22. Graphs showing:

19. Concentrations of lead, manganese, and zinc in streambed-sediment samples collected August 6-9, 2002, from Rio Grande/Río Bravo main-stem (MS) and tributary (TR) sites (downstream order) in the Big Bend area of the United States and Mexico

20. Detectable concentrations of arsenic, cadmium, and chromium in minetailing samples collected August 5-15, 2002, from abandoned mine and mine processing sites (downstream order) in the Big Bend area of the United States and Mexico

21. Detectable concentrations of copper, mercury, and nickel in mine-tailing samples collected August 5-15, 2002, from abandoned mine and mine processing sites (downstream order) in the Big Bend area of the United States and Mexico

22. Detectable concentrations of lead, manganese, silver, and zinc in minetailing samples collected August 5-15, 2002, from abandoned mine and mine processing sites (downstream order) in the Big Bend area of the United States and Mexico

\section{Tables}

1. Information on abandoned mines and mine processing areas sampled August 5-15, 2002, in the Big Bend area of the United States and Mexico

2. Locations of stream and abandoned mine and mine processing sites sampled August 5-15, 2002, in the Big Bend area of the United States and Mexico

3. Criteria and screening levels used to assess surface-water quality in segment 2306 of the Rio Grande/Río Bravo

4. Water-quality data from samples collected August 6-9, 2002, in the Big Bend area of the United States and Mexico

5. Streambed-sediment data from samples collected August 6-9, 2002, in the Big Bend area of the United States and Mexico

6. Mine-tailing data from samples collected August 5-15, 2002, in the Big Bend area of the United States and Mexico

7. Toxicity Characteristic Leaching Procedure leaching potential (concentrations) for mine-tailing samples collected August 5-15, 2002 (table 6) in the Big Bend area of the United States and Mexico 


\section{Conversion Factors and Datum}

\section{Inch/Pound to SI}

\begin{tabular}{|c|c|c|}
\hline Multiply & By & To obtain \\
\hline \multicolumn{3}{|c|}{ Length } \\
\hline foot $(\mathrm{ft})$ & 0.3048 & meter $(\mathrm{m})$ \\
\hline inch (in.) & 2.54 & centimeter $(\mathrm{cm})$ \\
\hline inch (in.) & 25.4 & millimeter (mm) \\
\hline mile (mi) & 1.609 & kilometer $(\mathrm{km})$ \\
\hline \multicolumn{3}{|c|}{ Flow } \\
\hline cubic foot per second $\left(\mathrm{ft}^{3} / \mathrm{s}\right)$ & 0.02832 & cubic meter per second $\left(\mathrm{m}^{3} / \mathrm{s}\right)$ \\
\hline \multicolumn{3}{|c|}{ Mass } \\
\hline pound avoirdupois (lb avdp) & 0.4536 & kilogram (kg) \\
\hline
\end{tabular}

Temperature in degrees Fahrenheit $\left({ }^{\circ} \mathrm{F}\right)$ may be converted to degrees Celsius $\left({ }^{\circ} \mathrm{C}\right)$ as follows: ${ }^{\circ} \mathrm{C}=\left({ }^{\circ} \mathrm{F}-32\right) / 1.8$

Temperature in degrees Celsius $\left({ }^{\circ} \mathrm{C}\right)$ may be converted to degrees Fahrenheit $\left({ }^{\circ} \mathrm{F}\right)$ as follows:

${ }^{\circ} \mathrm{F}=\left(1.8 x^{\circ} \mathrm{C}\right)+32$

Specific conductance is given in microsiemens per centimeter at 25 degrees Celsius $(\mu \mathrm{S} / \mathrm{cm}$ at $\left.25^{\circ} \mathrm{C}\right)$.

Concentrations of chemical constituents in water are given either in milligrams per liter (mg/L) or micrograms per liter $(\mu \mathrm{g} / \mathrm{L})$.

Concentrations of chemical constituents in streambed sediment are given in milligrams per kilogram $(\mathrm{mg} / \mathrm{kg})$. For sediment screening, micrograms per gram $(\mu \mathrm{g} / \mathrm{g})=\mathrm{mg} / \mathrm{kg}$.

\section{Datum}

Horizontal coordinate information is referenced to North American Datum of 1983 (NAD 83). 


\title{
Quality of Water and Sediment in Streams Affected by Historical Mining, and Quality of Mine Tailings, in the Rio Grande/Río Bravo Basin, Big Bend Area of the United States and Mexico, August 2002
}

\author{
By Rebecca B. Lambert, Christine M. Kolbe', and Wayne Belzer
}

\section{Abstract}

The U.S. Geological Survey, in cooperation with the International Boundary and Water Commission-U.S. and Mexican Sections, the National Park Service, the Texas Commission on Environmental Quality, the Secretaría de Medio Ambiente y Recursos Naturales in Mexico, the Área de Protección de Flora y Fauna Cañón de Santa Elena in Mexico, and the Área de Protección de Flora y Fauna Maderas del Carmen in Mexico, collected samples of stream water, streambed sediment, and mine tailings during August 2002 for a study to determine whether trace elements from abandoned mines in the area in and around Big Bend National Park have affected the water and sediment quality in the Rio Grande/Río Bravo Basin of the United States and Mexico. Samples were collected from eight sites on the main stem of the Rio Grande/ Río Bravo, four Rio Grande/Río Bravo tributary sites downstream from abandoned mines or mine-tailing sites, and 11 mine-tailing sites. Mines in the area were operated to produce fluorite, germanium, iron, lead, mercury, silver, and zinc during the late 1800s through at least the late 1970s. Moderate (relatively neutral) $\mathrm{pHs}$ in stream-water samples collected at the 12 Rio Grande/Río Bravo main-stem and tributary sites indicate that water is well mixed, diluted, and buffered with respect to the solubility of trace elements. The highest sulfate concentrations were in water samples from tributaries draining the Terlingua mining district. Only the sample from the Rough Run Draw site exceeded the Texas Surface Water Quality Standards general-use protection criterion for sulfate. All chloride and dissolved solids concentrations in water samples were less than the general-use protection criteria. Aluminum, copper, mercury, nickel, selenium, and zinc were detected in all water samples for which each element was analyzed. Cadmium, chromium, and lead were detected in samples less frequently, and silver was not detected in any of the samples. None of the sample concentrations of aluminum, cadmium,

${ }^{1}$ Texas Commission on Environmental Quality, Austin, Tex. Tex. chromium, nickel, selenium, and zinc exceeded the Texas Surface Water Quality Standards criteria for aquatic life-use protection or human health. The only trace elements detected in the water samples at concentrations exceeding the Texas Surface Water Quality Standards criterion for human health (fish consumption use) was lead at one site and mercury at 10 of 12 sites. Relatively high mercury concentrations distributed throughout the area might indicate sources of mercury in addition to abandoned mining areas. Streambed-sediment samples were collected from 12 sites and analyzed for 44 major and trace elements. In general, the trace elements detected in streambed-sediment samples were low in concentration, interpreted as consistent with background concentrations. Concentrations at two sites, however, were elevated compared to Texas Commission on Environmental Quality criteria. Concentrations of antimony, arsenic, cadmium, lead, silver, and zinc in the sample from San Carlos Creek downstream from La Esperanza (San Carlos) Mine exceeded the Texas Commission on Environmental Quality screening levels for sediment. The sample from Rough Run Draw, downstream from the Study Butte Mine, also showed elevated concentrations of arsenic, cadmium, and lead, but these concentrations were much lower than those in the San Carlos Creek sample and did not exceed screening levels. Elevated concentrations of multiple trace elements in streambed-sediment samples from San Carlos Creek and Rough Run Draw indicate that San Carlos Creek, and probably Rough Run Draw, have been adversely affected by mining activities. Fourteen mine-tailing samples from 11 mines were analyzed for 25 major and trace elements. All trace elements except selenium and thallium were detected in one or more samples. The highest lead concentrations were detected in tailings samples from the Boquillas, Puerto Rico, La Esperanza (San Carlos), and Tres Marias Mines, as might be expected because the tailings are from lead mines; the concentrations greatly exceeded the screening level for lead. Application of the Toxicity Characteristic Leaching Procedure to 14 samples from 11 abandoned mine and mine processing sites indicate that, in general, the leaching potential (concentration) was less than the Toxicity Characteristic Leaching Procedure limit. Cadmium and 
lead concentrations in the mine-tailings sample from San Carlos Mine exceeded the Toxicity Characteristic Leaching Procedure screening level for cadmium and lead, and the lead concentration in the mine-tailings sample from Boquillas Mine exceeded the screening level for lead.

\section{Introduction}

The Rio Grande/Río Bravo (RG/RB) forms the boundary in the Big Bend area between Texas in the United States and Coahuila and Chihuahua in Mexico (fig. 1). The $\mathrm{RG} / \mathrm{RB}$ is the primary source of water in the Big Bend area of the United States and Mexico (study area) and a source of habitat for wildlife and endangered species. Parks and protected areas in the study area include Big Bend National Park (BBNP), Big Bend Ranch State Park, and Black Gap State Wildlife Management Area in the United States, and Cañón de Santa Elena and Maderas del Carmen Protected Areas in Mexico (fig. 1). All of these parks and protected areas are downstream from the confluence of the Rio Conchos and the $\mathrm{RG} / \mathrm{RB}$. The Rio Conchos is the primary source of freshwater inflow to the RG/RB in the Big Bend area, and this inflow historically has dominated flow in the RG/RB during the summer rainy season (Davis, 1980).

The National Parks Conservation Association, a parks advocacy group, listed BBNP as one of the 10 most endangered national parks in the United States, in part because of the decreasing quantity and quality of the RG/RB (National Parks Conservation Association, 2001). One of the possible sources of contaminants that might adversely affect the quality of the RG/RB upstream from, and in, the BBNP and Mexican Protected Areas (fig. 1) is drainage from areas in the basin where mining for fluorite, germanium, iron, lead, mercury, silver, and zinc has occurred. Tailings from abandoned mines have been found along Terlingua Creek and Fresno Creek (BBNP) in the United States and along San Carlos Creek in the Cañón de Santa Elena Protected Area and Arroyo del Fortino in the Maderas Del Carmen Protected Area in Mexico (International Boundary and Water Commission, 2004)

(fig. 2).

Mercury was produced primarily from cinnabar ore (mercury sulfide) in the Big Bend area, and most of the historical production in the United States came from the Terlingua mining district west of BBNP (figs. 1, 2) (Swanson, 1995). Mining for mercury began at Terlingua in 1894, and the mines were worked continuously until 1946 (Swanson, 1995). Numerous abandoned mercury mines remain in the Terlingua Creek watershed (fig. 2). Gold, lead, and silver have been mined from the Shafter mining district on the flanks of the Chinati Mountains near Presidio (fig. 1). The locations of all abandoned mines are not shown on the available maps of the study area. Mine tailings from abandoned mines, some of which are shown on figure 2 , and other mines not shown on the available maps of the area, might contribute trace elements (metals) such as lead and zinc to San Carlos Creek and Arroyo del Fortino (fig. 2) and other tributaries downstream from abandoned mining areas (fig. 2). Flow from watersheds that drain into the RG/RB upstream from BBNP (figs. 1, 2) might transport sediment with trace elements from the abandoned mining areas to the RG/RB.

The presence of trace elements that might adversely affect water and sediment quality (arsenic, cadmium, chromium, copper, lead, selenium, silver, and thallium) has been documented in segment 2306 of the RG/RB; upward trends in mercury and zinc concentrations have been noted (International Boundary and Water Commission, 1997; Texas Natural Resource Conservation Commission, 1994). Elevated concentrations of these elements can be toxic to animals and humans; some of the trace elements are carcinogenic and mutagenic (Pais and Jones, 1997). There is increasing concern among park managers that elevated selenium and mercury concentrations present in prey species, including the endangered peregrine falcon, might affect the reproductive success of this species in BBNP (National Park Service, 2006).

The U.S. Geological Survey (USGS), as part of the National Stream Quality Accounting Network (NASQAN) program, conducted a study in cooperation with the International Boundary and Water Commission-U.S. and Mexican Sections (USIBWC and CILA), the National Park Service (NPS), the Texas Commission on Environmental Quality (TCEQ), the Secretaría de Medio Ambiente y Recursos Naturales (SEMARNAT) in Mexico, the Área de Protección de Flora y Fauna (APFF) Cañón de Santa Elena in Mexico, and the APFF Maderas del Carmen in Mexico. The study in August 2002 was done to characterize the quality of water, streambed sediment, and mine tailings in the RG/RB and its tributaries in the Big Bend area because of the potential for adverse effects of trace elements from abandoned mines on the water and sediment quality in the RG/RB Basin.

\section{Purpose and Scope}

This report summarizes results from the August 2002 collection of samples for analysis of quality of stream water, streambed sediment, and mine tailings and relates the sampling results to abandoned mines and mine processing activities in the study area. Samples from 23 locations that include eight main-stem RG/RB sites, four RG/RB tributary sites, and 11 mine-tailing sites were analyzed for concentrations of trace elements commonly associated with mining activities. Water samples also were analyzed for field properties ( $\mathrm{pH}$, specific conductance, temperature, dissolved oxygen, and alkalinity); major ions; dissolved solids (DS), total suspended solids (TSS), and volatile suspended solids (VSS); and nutrients. Major ions and DS are discussed as components of salinity. Salinity, as used in this report, is the amount of dissolved salts in water and is indicated by DS. A procedure designed to simulate the leaching of contaminants in landfills was applied to determine the leaching potential for 10 trace elements from 


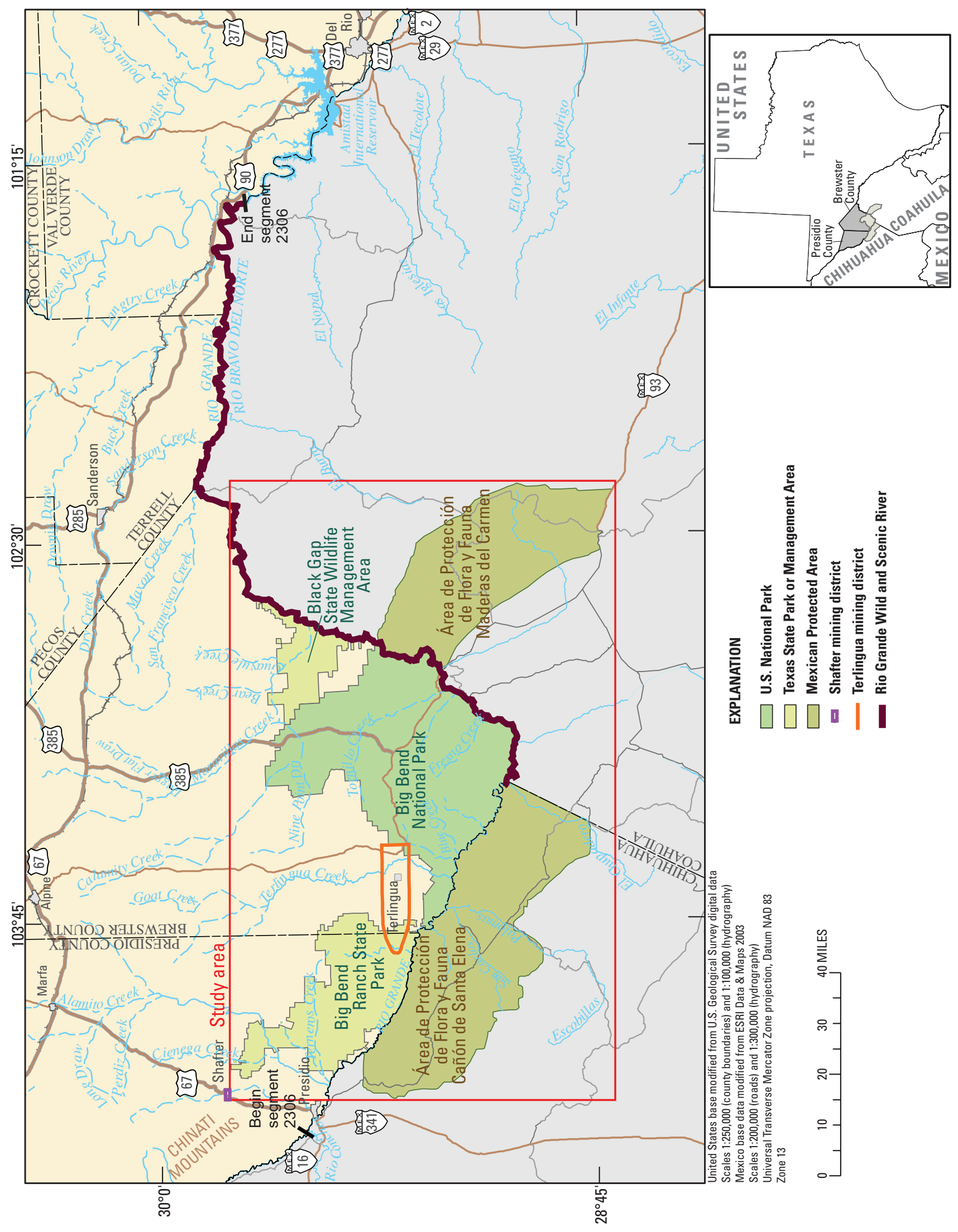

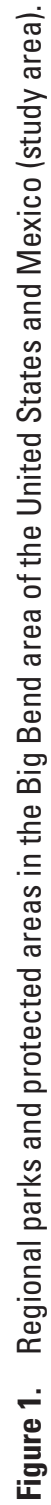



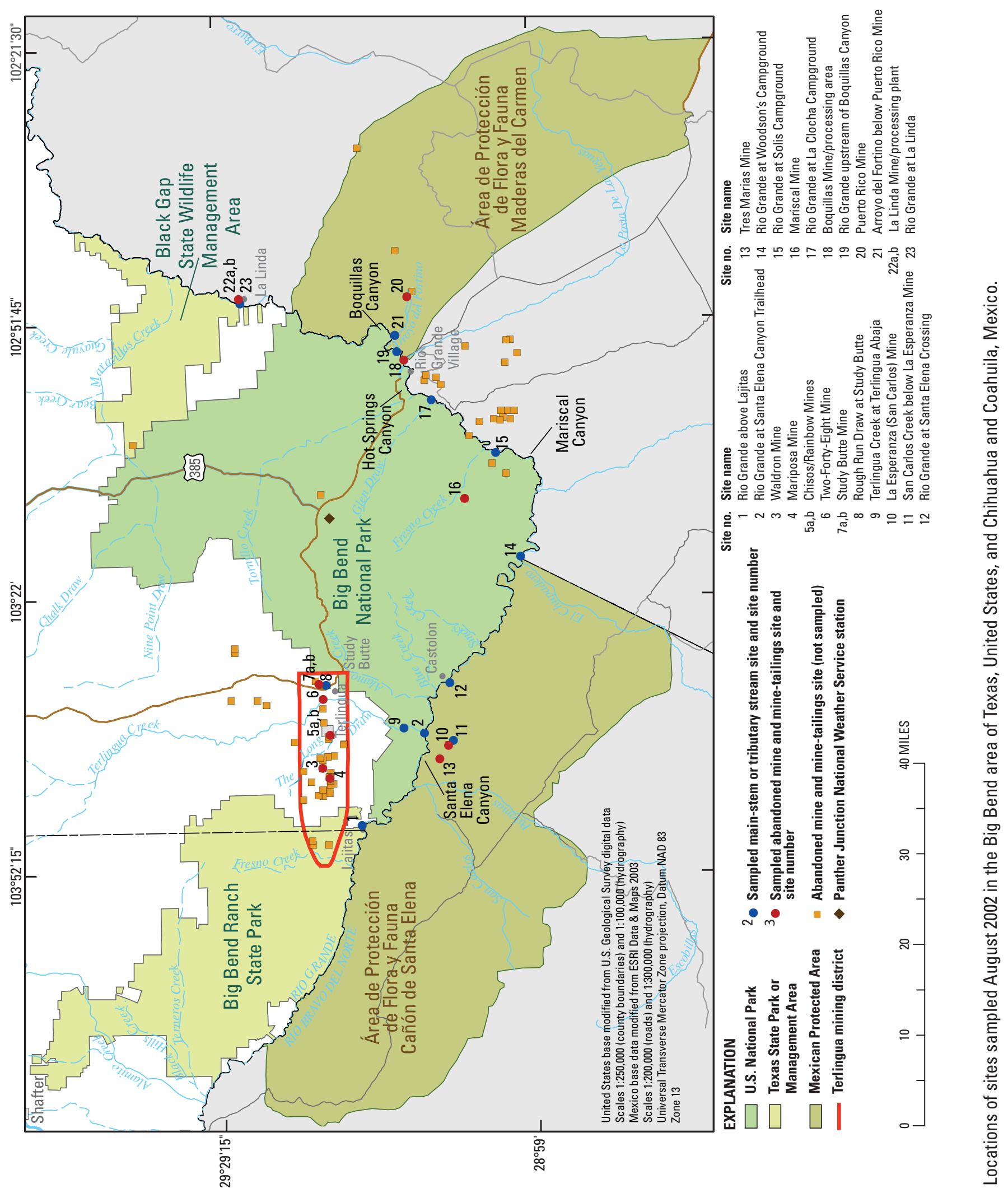

온 
14 samples collected at 11 abandoned mine and mine-tailing sites in the United States and Mexico. Summary statistics and graphical data analysis were computed or prepared for data from the main-stem and tributary sites and the mine-tailing sites. Results were compared to applicable standards and screening levels. Information on the abandoned mines in the study area was compiled. More specifically, this report (1) provides information on abandoned mines and mine processing areas in the Big Bend area of the United States including the ores and minerals mined throughout the study area at the major mining districts and individual mines; (2) statistically compares the results of trace elements and other constituent concentrations in stream-water, streambedsediment, and mine-tailing samples with criteria and screening levels established by TCEQ for segment 2306 of the RG/RB in the Big Bend area of the United States and Mexico; and (3) uses summary tables, truncated boxplots, scatterplots, and bar graphs to show constituent concentrations and summarize data distributions for samples collected in the Big Bend area of the United States and Mexico.

\section{Previous Investigations}

Several reports have been published that discuss the geology and mining activities in the Big Bend area. Yates and Thompson (1959) summarized the results of several geologic reconnaissances of the Terlingua mining district and described the occurrence of mercury deposits in specific mines in the mining district. Chester (1965) provided additional information on the history and production of mercury in West Texas in the Terlingua and other mining districts. Sharpe (1980) discussed the development of the mercury mining industry in the Trans-Pecos region of Texas (west of the Pecos River) and described some of the major mercury mines that were sampled during this study. Ragsdale (1976) wrote a history of the town of Terlingua and the history of the Chisos Mining Company, the largest historical producer of mercury in West Texas.

Recent studies completed in and near BBNP and ongoing monitoring programs provide some insight into existing water-quality conditions as well as identify some water-quality issues. Van Metre and others (1997) documented an increase in concentrations of arsenic, chromium, copper, lead, mercury, nickel, vanadium, and zinc from 1969 to 1994 in sediment core samples collected from the RG/RB arm of Amistad Reservoir. An analysis of historical (1970s to 1994) riverbed sediment data for the RG/RB Basin indicated upward trends in mercury and selenium concentrations in the region between the Pecos River and Amistad Reservoir (Lee and Wilson, 1997). Sources of these metals might include point and nonpoint sources associated with historic mining activities, as well as atmospheric deposition from fossil-fuel combustion and solid-waste incineration (Lee and Wilson, 1997).

Water-quality and suspended-sediment data were collected during 1999-2007 as part of the USGS NASQAN program at two sites on the RG/RB-Rio Grande below Rio
Conchos near Presidio, Tex. (station 08374200), and Rio Grande at Foster Ranch near Langtry, Tex. (station 08377200) (U.S. Geological Survey, 2006). Horowitz and others (2001) analyzed the suspended-sediment flux in the RG/RB using the NASQAN sediment-quality dataset for the 1996-98 water years (October 1, 1995-September 30, 1998) and determined that the majority (more than 70 percent) of trace elements, including aluminum, arsenic, barium, chromium, copper, iron, manganese, nickel, phosphorus, and zinc, are transported predominantly in association with the movement of suspended sediment. They found that the transport of strontium seems to be dominated by the dissolved phase, although the transport of lithium and total organic carbon seems to be equally divided between the suspended sediment and dissolved phases. Horowitz and others (2001) concluded that suspendedsediment fluxes in the RG/RB Basin are highly localized and extremely "flashy."

Gutierrez (2000) conducted a study in the lower Rio Conchos Basin in Chihuahua, Mexico, documenting trace element concentration patterns in stream sediment. Using a two-step sequential extraction method, Gutierrez studied the distribution of boron, chromium, copper, lead, nickel, and vanadium in stream sediment in the lower Rio Conchos Basin. By correlating trace element concentrations in stream sediment and water, Gutierrez was able to differentiate between trace elements retained by sediment in the Rio Conchos and those not retained. Chromium, copper, and nickel concentrations in water showed statistically significant correlations with stream sediment, and boron, lead, and vanadium did not, indicating that some trace elements are stored longer in the stream sediment and others apparently are released more quickly into the water.

The TCEQ has identified several trace elements of concern in the RG/RB upstream from BBNP including arsenic, cadmium, chromium, copper, lead, mercury, selenium, silver, thallium, and zinc (International Boundary and Water Commission, 1997; Texas Natural Resource Conservation Commission, 1994). The TCEQ has established Texas Surface Water Quality Standards (TSWQS) for segment 2306 of the RG/ $\mathrm{RB}$, a 313-mile reach from the inflow to Amistad Reservoir upstream to the confluence with the Rio Conchos near Presidio (Texas Commission on Environmental Quality, 2000).

The uses designated for segment 2306 include public water supply, contact recreation, human health (fish consumption), and high aquatic life use (Texas Commission on Environmental Quality, 2000). This segment generally supports the designated uses. However, in the upper 25 miles of this reach, ambient sediment and water toxicity occasionally has exceeded the criteria for the protection of aquatic life. The suspected cause of the toxicity is the salinity in the reach of the RG/RB downstream from El Paso. As of 2004, there was no evidence to support trace elements as the cause of the toxicity (Texas Commission on Environmental Quality, 2004).

Gray and others (2006) studied the speciation and microbial transformation of mercury from mine waste at selected mines in BBNP and the adjacent Terlingua mining district. 
Results of their study indicate that methyl mercury concentrations in mine waste correlate positively with concentrations of mercury, organic carbon, and sulfur, which are substances that influence processes of mercury cycling and methylation. They concluded that although the concentrations of total mercury and methyl mercury are locally high in some of the mine wastes, there is little offsite movement of mercury from the mines into stream sediment primarily because of the arid climate and lack of precipitation and mine runoff in the region. On the basis of the work by Horowitz and others (2001), movement of mercury from the mines into stream sediment is primarily in response to extreme runoff events.

\section{Acknowledgments}

The study was a binational cooperative effort by personnel from multiple agencies from both the United States and Mexico. The study participants included

\begin{tabular}{lc}
\hline \multicolumn{1}{c}{ United States } & \multicolumn{1}{c}{ Mexico } \\
\hline $\begin{array}{c}\text { Gilbert Anaya, USIBWC, El Paso } \\
\text { (lead) }\end{array}$ & $\begin{array}{c}\text { Javier Aceves Monarrez, CILA, } \\
\text { Ciudad Juarez (lead) } \\
\text { Pablo Dominguez, SEMARNAT, } \\
\text { Coahuila } \\
\text { Carlos Duarte, USIBWC, El Paso } \\
\text { del Carmen }\end{array}$ \\
Wayne Belzer, USIBWC, El Paso & \\
Rebecca Lambert, USGS, San Antonio & \\
(lead) & \\
Brian Petri, USGS, San Antonio \\
Michael Nyman, USGS, San Antonio \\
Jason Faith, USGS, San Antonio \\
Ted Small, USGS, San Antonio \\
Christine Kolbe, TCEQ, Austin (lead) \\
Roger Miranda, TCEQ, Austin
\end{tabular}

The authors thank the many property owners who provided access to the mining areas and also assisted in the data collection. Also, the authors thank the many individuals from all agencies in the United States and Mexico who worked together to make the sampling a success. Finally, the memory of Ted Small (1923-2007) is honored. Ted was a very humble man and a great friend who worked for more than 50 years in the region and whose knowledge of the Big Bend area was unparalleled. He was always willing to share his thoughts and to graciously answer questions. He was a mentor and source of information for many of the geologists who have worked in this region.

\section{Physical Setting}

The Big Bend area is a rugged, arid area in West Texas in the United States and in Coahuila and Chihuahua in Mexico (fig. 1). Located in the northern part of the Chihuahuan Desert, the Big Bend area generally receives little precipitation during the year. The normal annual precipitation (1971-2000) at the Panther Junction National Weather Service station in BBNP is 14.24 inches (National Climatic Data Center, 2005) (fig. 2). The lower altitudes along the RG/RB banks, where many of the abandoned mines are, generally receive less precipitation than that received at stations in higher altitudes, such as the Panther Junction weather station.

\section{Geologic Setting}

The Big Bend area is noted for its variety of geologic formations and structural features. These formations include thick sections of marine and continental Cretaceous deposits, bedded continental deposits, and Tertiary volcanic deposits and igneous intrusions (Maxwell and Dietrich, 1965). The deposition of these geologic units and the structural deformation and igneous activity that occurred during the Tertiary Period produced most of the ore deposits that have been mined in this area of the United States and Mexico, which in turn yields most of the trace elements that occur in streambed sediment.

The geologic formations in the Big Bend area range in age from early Paleozoic to Tertiary, although almost all the stratified rocks exposed in the Terlingua mining district are of Cretaceous age (Yates and Thompson, 1959). Magmatic activity during the Tertiary (48 to 20 million years ago) deposited thick sections of volcanic tuff across the region and intruded the Cretaceous-age limestones as shallow dikes, sills, laccoliths, and stocks (Sharpe, 1980). The structure of the Terlingua mining district is dominated by large domes and grabens (Yates and Thompson, 1959).

On a smaller scale, the rocks also have been irregularly deformed by intrusion, offset by innumerable faults, and pierced by breccia pipes (Yates and Thompson, 1959). Breccia pipes and other features that contain economic quantities of trace elements are formed by secondary solution and precipitation of solutes. There are three main types of solution features-open limestone caverns, filled caverns or cave-fill zones, and breccia pipes (Yates and Thompson, 1959), and two types of the open limestone caverns - vertical caves developed mainly along fractures and horizontal caves developed mainly along bedding planes.

\section{Historical Mining Areas}

Mines in the Big Bend area were operated from the late 1800s through at least the late 1970s (table 1). Fluorite, lead, mercury, silver, and zinc are the most common types of mines in the area. The mines in the United States produced mainly mercury, while the mines in Mexico produced fluorite, lead, silver, and zinc. The most productive historical mercury mines are aligned from west to east in a narrow zone of fracturing along the axis of the Terlingua monocline, a steep, southwarddipping fold exposed along the south flank of the Terlingua uplift (Chester, 1965). These geologic structures have further 


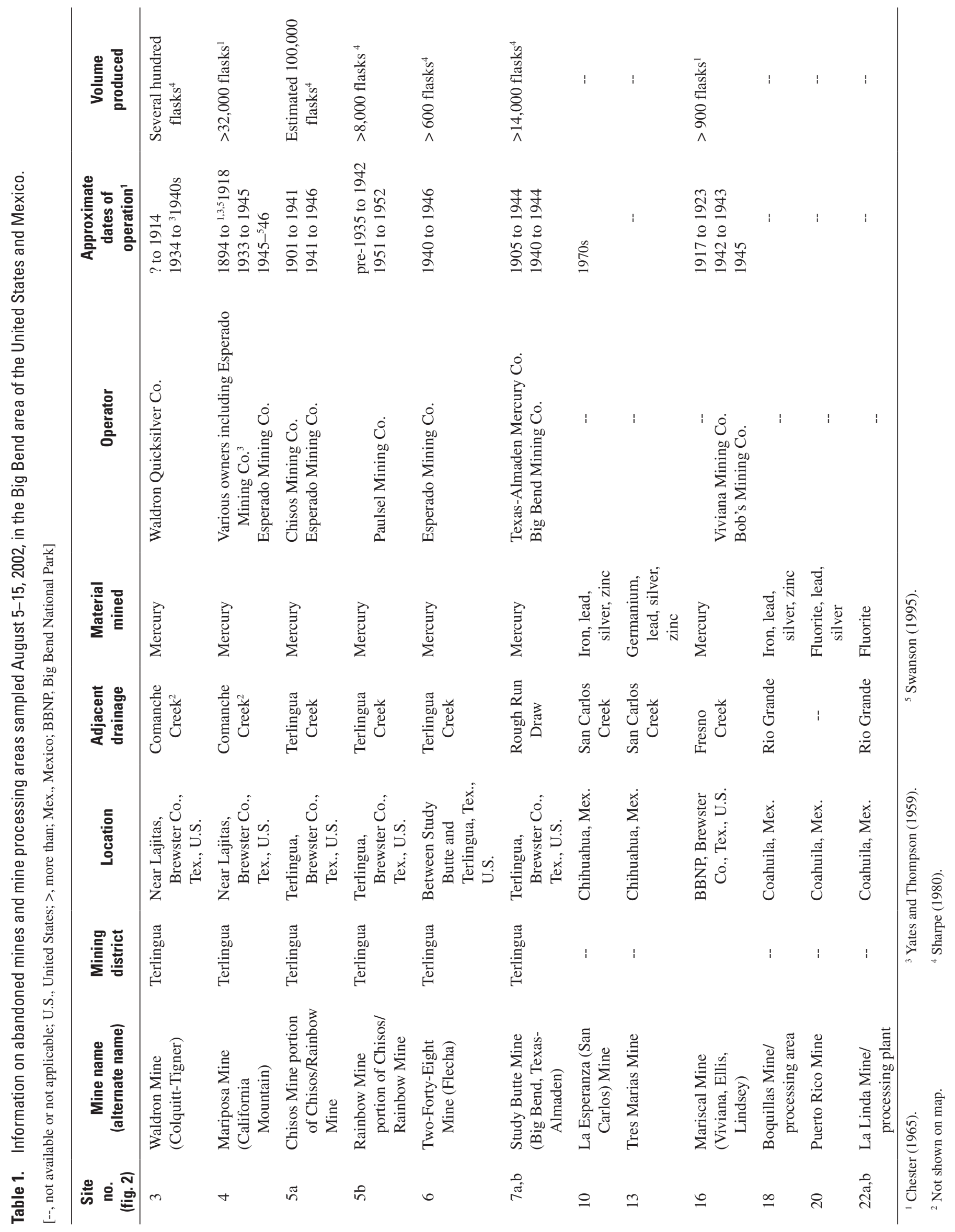


been modified by faults, en echelon fracture zones, and collapse features. The majority of faults are normal faults that bound downthrown grabens (Chester, 1965).

Cinnabar, the primary ore from which mercury is derived, was mined primarily from Cretaceous-age limestones (Sharpe, 1980). Cinnabar commonly occurs as a secondary replacement mineral in argillaceous breccia matrix or as vein fillings in, or near, volcanic rocks and hot springs. After mining and crushing, the mercury then was extracted from the ore concentrates by heating the ore in retorts, or furnaces, in the presence of air (oxygen) to release the metal as a vapor that when cooled condensed to liquid mercury. The liquid mercury, also called quicksilver, was bottled for distribution in 76-pound steel cylinders called flasks.

The Terlingua mining district and adjacent smaller districts in Brewster and Presidio Counties in Texas produced more than 150,000 flasks of mercury from 1899 to 1970 (Sharpe, 1980). The total reported output of mercury from Texas from 1897 to 1960 was more than 147,200 flasks, or about 9 percent of the new mercury produced in the United States during the same period (Chester, 1965). The major mercury-producing mines or groups of mines in Texas that were sampled for this study include the Chisos/Rainbow Mines, Mariposa (California Mountain) Mine, Study Butte (Big Bend, Texas-Almaden) Mine, Two-Forty-Eight (Flecha) Mine, and Waldron (Colquitt-Tigner) Mine. More than 90 percent of the mercury in the Terlingua mining district was produced from the Mariposa, Chisos/Rainbow, and Study Butte Mines (figs. 2, 3) (Sharpe, 1980). A number of other mines, including the La Esperanza (San Carlos), Tres Marias, Boquillas, Puerto Rico, and La Linda Mines in Mexico, were mined for fluorite, lead, silver, and zinc, but there is little information available for these mines (figs. 2, 3).

\section{Chisos/Rainbow Mines}

The Chisos Mine (fig. 2; table 1), one of the oldest mines and the most productive mercury mine in the Terlingua mining district, is at the middle part of The Long Draw (Sharpe, 1980). The Chisos Mine was the only mine in the Terlingua mining district that economically produced cinnabar from calcite veins (Sharpe, 1980). The Chisos Mine connects with the adjoining Rainbow Mine, one of the deepest and most productive mines in the Terlingua mining district at a reported shaft depth of 670 feet (Yates and Thompson, 1959). The shaft follows a fault zone for much of its extent. The ore that was mined was obtained from altered limestones and clays, with high-grade cinnabar occurring along fractures and in irregular replacements.

\section{Mariposa (California Mountain) Mine}

The Mariposa Mine (fig. 2; table 1) ranks second in production of mercury in the Terlingua mining district (Yates and Thompson, 1959). Between 1895 and 1945, the
Mariposa Mine produced more than 32,000 flasks of mercury (Chester, 1965). Ore from the Mariposa Mine was produced from cave-fill zones that are typical of the limestone-clay contact deposits in the Terlingua mining district (Yates and Thompson, 1959). The principal ore mineral is cinnabar, but there also are appreciable quantities of native mercury and other rare mercury minerals. The cinnabar occurs as disseminations and as solid masses in the clay matrix of the cavefill, and to a lesser extent, as veinlets and disseminations in limestone (Yates and Thompson, 1959). Most of the ore was produced before 1911, but some was mined during World War I and again from 1933 to 1945. By March, 1945, no appreciable ore reserves remained and the mine was closed (Yates and Thompson, 1959).

\section{Study Butte (Big Bend, Texas-Almaden) Mine}

About the same time that mercury was discovered in the Terlingua area, it also was found farther east in the area of the Study Butte Mine and the Two-Forty-Eight Mine (fig. 2; table 1) (Yates and Thompson, 1959). The Study Butte Mine was the third largest producer of mercury in the Terlingua mining district and essentially marks the eastern end of the Terlingua mining district about 5 miles east of Terlingua. Cinnabar was discovered early in 1902 and was actively mined as early as 1905 , although substantial production did not begin until World War I (Yates and Thompson, 1959). The Study Butte Mine consists of two adjacent properties, the Big Bend and the Texas-Almaden, which historically have been worked either individually or as a single unit. The mine structure includes four principal shafts with many associated minor shafts, and more than 3 miles of horizontal workings on four main and numerous sublevels (Yates and Thompson, 1959). The workings of the Study Butte Mine are almost entirely in the Study Butte quartz soda syenite intrusion, which forms the hill that gives the mine its name (Yates and Thompson, 1959). Cinnabar occurs in association with igneous rocks in several places in the Terlingua mining district, but the Study Butte Mine was the only economic producer from this type of mercury source (Sharpe, 1980).

\section{Two-Forty-Eight (Flecha) Mine}

The Two-Forty-Eight (Flecha) Mine consists of a breccia pipe with a mine shaft greater than 600 feet deep that has produced cinnabar (Yates and Thompson, 1959). The TwoForty-Eight Mine (fig. 2; table 1) is 2 miles east of Terlingua and is named for section 248 where it is located (Yates and Thompson, 1959). Cinnabar was discovered before 1902, but by 1934 only 700 feet of subsurface workings had been driven (Yates and Thompson, 1959). In the 1940s, the Esperado Mining Company extended the mine workings to more than 7,000 feet with 13 different levels that extended from the main shaft at irregular intervals (Yates and Thompson, 1959). The mercury deposits from the Two-Forty-Eight Mine can be 

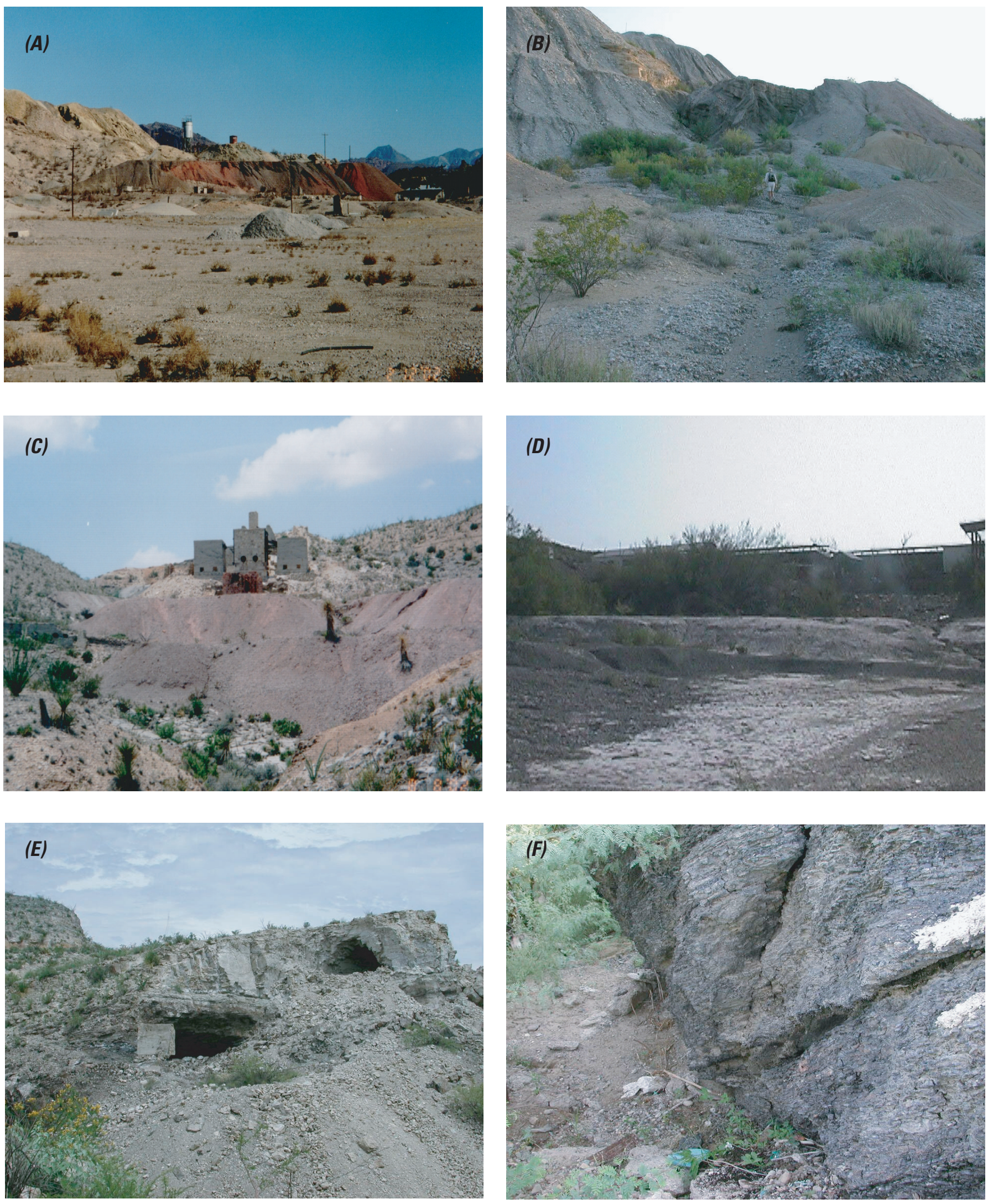

Figure 3. Examples of mine and mine-tailing sample sites at (A) Study Butte Mine, (B) Chisos Mine, (C) Mariscal Mine, (D) La Linda Mine/processing plant, (E) La Esperanza (San Carlos) Mine, and (F) Boquillas Mine (tailings). 
divided into two groups - the first and more important group includes deposits in marginal fissures of the breccia pipe and within the breccia pipe. The second group comprises fillings along fractures outside of, and away from, the breccia pipe. The most productive breccia pipes in the Terlingua mining district were from the Chisos and Two-Forty-Eight Mines (fig. 2).

\section{Waldron (Colquitt-Tigner) Mine}

The Waldron Mine (fig. 2; table 1) is northeast of the Mariposa Mine, and consists of about 900 feet of horizontal or near-horizontal passageways (Sharpe, 1980). The principal workings of the mine run approximately parallel to complementary fracture planes in a steep zone of brecciated and altered limestone (Sharpe, 1980). The Waldron mine is a "solution cavern" type of mine where calcite in small crystals coats some of the breccia and coarser calcite bands and, in part, fills vugs in the limestone (Yates and Thompson, 1959).

\section{Contributors of Flow, Sediment, Mercury, and Other Trace Elements}

In the upper part of the study area, runoff from the Waldron Mine, Mariposa Mine, Chisos/Rainbow Mines, and Two-Forty-Eight Mine contributes flow and sediment to the Terlingua Creek watershed (fig. 2). The Study Butte Mine contributes flow and sediment to the adjacent Rough Run Draw, which is a subwatershed of the Terlingua Creek watershed. All of these mines are part of the Terlingua mining district and have the potential to contribute mercury and other trace elements associated with mercury deposits and mining to Terlingua Creek and also to the upper part of the RG/RB in the study area. The San Carlos Mine and the Tres Marias Mine produced lead, silver, and zinc and can contribute these trace elements and runoff to San Carlos Creek and to the upper part of the RG/RB (fig. 2). The Mariscal Mine in BBNP contributes flow and sediment from mercury deposits to Fresno Creek, a tributary of the RG/RB. The Boquillas Mine/processing area can contribute lead, silver, and zinc in flow and sediment directly to the RG/RB upstream from Boquillas Canyon (fig. 2). The Puerto Rico Mine in Coahuila can contribute lead and fluorite to the Arroyo del Fortino. Farther downstream, the La Linda mine/processing plant can contribute fluorite and other trace elements directly to the RG/RB near La Linda, Mexico (fig. 2).

\section{Methods}

Water, streambed-sediment, and mine-tailing samples were collected in August 2002 from eight RG/RB main-stem sites, four RG/RB tributary sites downstream from abandoned mines or mine tailings, and 11 mine-tailing sites, one of which also is a specific-source site (holding tank) (fig. 2; table 2). Summary statistics (minimum, maximum, average, median, and standard deviation) were computed for data from RG/RB main-stem and tributary sites and mine-tailing sites. In addition to scatterplots and bar graphs, truncated boxplots with whiskers drawn to 90th and 10th percentiles of the data set were used to summarize the distribution of data for selected constituents (Helsel and Hirsch, 1992). In all cases where boxplots were prepared to visually display the data distribution, the number of data points was eight or greater.

The Texas Surface Water Quality Standards (TSWQS), Title 30, Chapter 307 of the Texas Administrative Code, are written by TCEQ with the authority of Section 303(c) of the Clean Water Act and Section 26.023 of the Texas Administrative Code. The standards establish specific water-quality goals for specific stream segments, lakes, and reservoirs throughout Texas. The standards are established to maintain the quality of water in Texas consistent with public health and recreation uses and also to protect aquatic life (Texas Commission on Environmental Quality, 2006). The TSWQS include specific numerical criteria for 39 toxic contaminants, maximum allowable in-stream concentrations for specified constituents, and criteria needed to protect aquatic life. Concentrations that exceed the criteria are considered indicators of potential shortterm (acute) and long-term (chronic) effects on aquatic life. Human consumption of fish and drinking water is protected by numerical criteria for 65 toxic contaminants. Concentrations that exceed the criteria indicate a long-term exposure risk and represent a potential human health hazard if untreated water or fish from a water body are consumed on a regular, long-term basis (table 3).

In-stream concentrations of nutrients, toxic substances in sediment, and salinity are used to identify water-quality issues. Numerical criteria for these constituents have not been established in the TSWQS. The screening levels for these constituents establish targets that can be directly related to in-stream data. The screening levels are statistically derived from long-term monitoring data (for example, nutrients) or are based on published levels of concern (for example, sediment). For this study, these criteria and screening levels are only used as tools to screen the data for assessment purposes. A larger data set would be required to determine if a particular reach supports the designated water-quality standards using these criteria (Texas Commission on Environmental Quality, 2006).

Where applicable, water-quality and sediment-quality data were compared with TSWQS criteria and screening levels (table 3) for selected constituents as a measure of the effect of the abandoned mines. The use of criteria and screening levels to assess water-quality conditions is documented in the "Guidance for Assessing and Reporting Surface Water Quality in Texas" (Texas Commission on Environmental Quality, 2006). Analytical data from the sample collected from the specific-source site (holding tank) was included in the report for informational purposes only regarding the chemical composition of similar sites that might exist elsewhere in the study area. The data from the specific-source site was not included in the analysis of main-stem and tributary water and sediment quality. 
Table 2. Locations of stream and abandoned mine and mine processing sites sampled August 5-15, 2002, in the Big Bend area of the United States and Mexico.

[ddmmss, degrees minutes seconds; MS, main stem; SW, stream-water quality; BS, streambed-sediment quality; MT, mine-tailing; LP, leaching potential; TR, tributary; BBNP, Big Bend National Park; SS, specific source]

\begin{tabular}{|c|c|c|c|c|c|c|}
\hline $\begin{array}{c}\text { Site } \\
\text { no. } \\
\text { (fig. 2) }\end{array}$ & Site name and general location & Sample identifier & $\begin{array}{l}\text { Site } \\
\text { type }\end{array}$ & $\begin{array}{c}\text { Type of } \\
\text { analysis } \\
\text { or sample } \\
\text { medium }\end{array}$ & $\begin{array}{l}\text { Latitude } \\
\text { (ddmmss) }\end{array}$ & $\begin{array}{l}\text { Longitude } \\
\text { (ddmmss) }\end{array}$ \\
\hline 1 & Rio Grande above Lajitas, Texas, United States & MS-Lajitas & MS & SW/BS & $29^{\circ} 15^{\prime} 54.9^{\prime \prime}$ & $103^{\circ} 46^{\prime} 59.8^{\prime \prime}$ \\
\hline 2 & $\begin{array}{l}\text { Rio Grande at Santa Elena Canyon Trailhead, } \\
\text { BBNP, United States }\end{array}$ & $\begin{array}{l}\text { MS-Santa Elena } \\
\text { Canyon }\end{array}$ & MS & SW/BS & $29^{\circ} 09^{\prime} 51.1^{\prime \prime}$ & $103^{\circ} 36^{\prime} 55.8^{\prime \prime}$ \\
\hline 4 & Mariposa Mine, Texas, United States & Mariposa & MT & Rock/LP & $29^{\circ} 18^{\prime} 56.2^{\prime \prime}$ & $103^{\circ} 41^{\prime} 53.9^{\prime \prime}$ \\
\hline $5 a, b$ & Chisos/Rainbow Mine, Texas, United States & Chisos 1,2 & MT & Rock/LP & $29^{\circ} 19^{\prime} 00^{\prime \prime}$ & $103^{\circ} 37^{\prime} 15^{\prime \prime}$ \\
\hline 6 & Two-Forty-Eight Mine, Texas, United States & 248 & MT & Rock/LP & $29^{\circ} 19^{\prime} 34.5^{\prime \prime}$ & $103^{\circ} 34^{\prime} 04^{\prime \prime}$ \\
\hline 9 & $\begin{array}{l}\text { Terlingua Creek at Terlingua Abaja, BBNP, } \\
\text { United States }\end{array}$ & $\begin{array}{l}\text { TR-Terlingua } \\
\text { Creek }\end{array}$ & TR & SW/BS & $29^{\circ} 11^{\prime} 59^{\prime \prime}$ & $103^{\circ} 36^{\prime} 19^{\prime \prime}$ \\
\hline 10 & $\begin{array}{l}\text { La Esperanza (San Carlos) Mine, Chihuahua, } \\
\text { Mexico }\end{array}$ & San Carlos & MT & Rock/LP & $29^{\circ} 07^{\prime} 35.2^{\prime \prime}$ & $103^{\circ} 38^{\prime} 16.8^{\prime \prime}$ \\
\hline 11 & $\begin{array}{l}\text { San Carlos Creek below La Esperanza Mine, } \\
\text { Chihuahua, Mexico }\end{array}$ & $\begin{array}{l}\text { TR-San Carlos } \\
\quad \text { Creek }\end{array}$ & $\mathrm{TR}$ & SW/BS & $29^{\circ} 07^{\prime} 3.2^{\prime \prime}$ & $103^{\circ} 37^{\prime} 48.5^{\prime \prime}$ \\
\hline 12 & $\begin{array}{l}\text { Rio Grande at Santa Elena Crossing, BBNP, } \\
\text { United States }\end{array}$ & $\begin{array}{l}\text { MS-Santa Elena } \\
\text { Crossing }\end{array}$ & MS & SW/BS & $29^{\circ} 07^{\prime} 20.8^{\prime \prime}$ & $103^{\circ} 31^{\prime} 25.2^{\prime \prime}$ \\
\hline 17 & $\begin{array}{l}\text { Rio Grande at La Clocha Campground, BBNP, } \\
\text { United States }\end{array}$ & MS-La Clocha & MS & SW/BS & $29^{\circ} 08^{\prime} 54.9^{\prime \prime}$ & $103^{\circ} 00^{\prime} 27.9^{\prime \prime}$ \\
\hline 18 & $\begin{array}{l}\text { Boquillas Mine/processing area, Coahuila, } \\
\text { Mexico }\end{array}$ & Boquillas & MT & Rock/LP & $29^{\circ} 11^{\prime} 18.3^{\prime \prime}$ & $102^{\circ} 56^{\prime} 6.3^{\prime \prime}$ \\
\hline 19 & $\begin{array}{l}\text { Rio Grande upstream of Boquillas Canyon, } \\
\text { BBNP, United States }\end{array}$ & $\begin{array}{l}\text { MS-Boquillas } \\
\text { Canyon }\end{array}$ & MS & SW/BS & $29^{\circ} 11^{\prime} 57.2^{\prime \prime}$ & $102^{\circ} 55^{\prime} 04.7^{\prime \prime}$ \\
\hline 20 & Puerto Rico Mine, Coahuila, Mexico & Puerto Rico & MT & Rock/LP & $29^{\circ} 10^{\prime} 55.4^{\prime \prime}$ & $102^{\circ} 49^{\prime} 9.3^{\prime \prime}$ \\
\hline 21 & $\begin{array}{l}\text { Arroyo del Fortino below Puerto Rico Mine } \\
\text { near Boquillas, Coahuila, Mexico }\end{array}$ & $\begin{array}{l}\text { TR-Arroyo del } \\
\text { Fortino }\end{array}$ & TR & SW/BS & $29^{\circ} 12 ' 21.4^{\prime \prime}$ & $102^{\circ} 53^{\prime} 21.1^{\prime \prime}$ \\
\hline $22 \mathrm{a}, \mathrm{b}$ & $\begin{array}{l}\text { La Linda Mine/processing plant near La Linda, } \\
\text { Coahuila, Mexico }\end{array}$ & SS-La Linda 1, 2 & $\mathrm{SS}^{1}(\mathrm{MT})$ & $\begin{array}{l}\text { SW/Rock/ } \\
\text { LP/BS }\end{array}$ & $29^{\circ} 27^{\prime} 06^{\prime \prime}$ & $102^{\circ} 49^{\prime} 04^{\prime \prime}$ \\
\hline 23 & Rio Grande at La Linda, Coahuila, Mexico & MS-La Linda & MS & SW/BS & $29^{\circ} 26^{\prime} 57.5^{\prime \prime}$ & $102^{\circ} 49^{\prime} 22.8^{\prime \prime}$ \\
\hline
\end{tabular}

${ }^{1}$ Sample of stream water (site 22, table 4) collected from holding tank at mine-tailing site; sample of streambed sediment (site 22, table 5) collected from creek downstream from processing plant; samples of mine tailings (site 22a,b, tables 6-7) collected from mine tailings at processing plant 1, 2. 
Table 3. Criteria and screening levels used to assess surface-water quality in segment 2306 of the Rio Grande/Río Bravo (Texas Commission on Environmental Quality, 2006).

$[\mu \mathrm{g} / \mathrm{L}$, micrograms per liter; mg/L, milligrams per liter; mg/kg, milligrams per kilogram; $\mu \mathrm{g} / \mathrm{g}$, micrograms per gram; TCLP, Toxicity Characteristic Leaching Procedure; --, not applicable; ${ }^{\circ} \mathrm{C}$, degrees Celsius; DO, dissolved oxygen; DS, dissolved solids]

\begin{tabular}{|c|c|c|c|c|c|c|c|c|}
\hline \multirow{2}{*}{ Constituent } & \multicolumn{2}{|c|}{$\begin{array}{c}\text { Aquatic life-use protection }{ }^{1} \\
(\mu \mathrm{g} / \mathrm{L})\end{array}$} & \multicolumn{2}{|c|}{$\begin{array}{l}\text { Human health criteria }{ }^{2} \\
(\mu \mathrm{g} / \mathrm{L})\end{array}$} & \multirow{2}{*}{$\begin{array}{c}\text { General-use } \\
\text { protection } \\
\text { criteria }^{3}\end{array}$} & \multicolumn{2}{|c|}{ Screening levels ${ }^{4}$} & \multirow{2}{*}{$\begin{array}{c}\text { TCLP } \\
\text { screening } \\
\text { limit }^{6} \\
(\mathrm{mg} / \mathrm{L})\end{array}$} \\
\hline & $\begin{array}{l}\text { Acute } \\
\text { criteria }\end{array}$ & $\begin{array}{l}\text { Chronic } \\
\text { criteria }\end{array}$ & $\begin{array}{l}\text { Fish con- } \\
\text { sumption use }\end{array}$ & $\begin{array}{l}\text { Public water } \\
\text { supply use }\end{array}$ & & $\begin{array}{c}\text { Nutrients } \\
\text { (mg/L) }\end{array}$ & $\begin{array}{l}\text { Sediment }{ }^{5} \\
(\mathrm{mg} / \mathrm{kg})\end{array}$ & \\
\hline & & & & & & & & \\
\hline pH (units) & -- & -- & -- & -- & $6.5-9.0$ & -- & -- & -- \\
\hline Temperature $\left({ }^{\circ} \mathrm{C}\right)$ & -- & -- & -- & -- & 32.2 & -- & -- & -- \\
\hline $\mathrm{DO}(\mathrm{mg} / \mathrm{L})$ & -- & -- & -- & -- & 5 & -- & -- & -- \\
\hline Chloride (mg/L) & -- & -- & -- & -- & 300 & -- & -- & -- \\
\hline Sulfate $(\mathrm{mg} / \mathrm{L})$ & -- & -- & -- & -- & 570 & -- & -- & -- \\
\hline $\mathrm{DS}(\mathrm{mg} / \mathrm{L})$ & -- & -- & -- & -- & 1,500 & -- & -- & -- \\
\hline & & & & & & & & \\
\hline Phosphorus & -- & -- & -- & -- & -- & 0.69 & -- & -- \\
\hline Orthophosphorus & -- & -- & -- & -- & -- & .37 & -- & -- \\
\hline Nitrite + nitrate & -- & -- & -- & -- & -- & 2 & -- & -- \\
\hline Ammonia & -- & -- & -- & -- & -- & .33 & -- & -- \\
\hline Aluminum & 991 & -- & -- & -- & -- & -- & -- & -- \\
\hline Antimony & - & -- & -- & -- & -- & -- & 25 & 1 \\
\hline Arsenic & 360 & 190 & -- & 50 & -- & -- & 33 & 5 \\
\hline Barium & -- & -- & -- & 2,000 & -- & -- & -- & 100 \\
\hline Beryllium & -- & -- & -- & -- & -- & -- & -- & .08 \\
\hline Cadmium & 92.1 & 2.1 & -- & 5 & -- & -- & 4.98 & 1 \\
\hline $\begin{array}{l}\text { Chromium }(0, \text { III } \\
\text { and VI) }\end{array}$ & 1,162 & 377 & 100 & 100 & -- & -- & 111 & 5 \\
\hline Copper & 43.7 & 26.9 & -- & -- & -- & -- & 149 & -- \\
\hline Lead & 233 & 8.1 & 4.98 & -- & -- & -- & 128 & 5 \\
\hline Mercury & 2.4 & 1.3 & .0122 & -- & -- & -- & 1.06 & .2 \\
\hline Nickel & 3,073 & 341 & -- & -- & -- & -- & 48.6 & 70 \\
\hline Selenium & 20 & 5 & 50 & -- & -- & -- & -- & 1 \\
\hline Silver & .8 & -- & -- & -- & -- & -- & 2.2 & 5 \\
\hline Zinc & 248.8 & 227.1 & -- & -- & -- & -- & 459 & -- \\
\hline
\end{tabular}

${ }^{1}$ Includes acute and chronic criteria for metals and organics in water, DO, toxicity in water and sediment, sediment contaminants, biological communities, and in-stream habitat.

${ }^{2}$ Established in Texas Surface Water Quality Standards (TSWQS), designed to prevent contamination of drinking water, fish, and other aquatic life, to ensure safe use for human consumption.

${ }^{3}$ Water-quality criteria established in TSWQS to safeguard general water quality, rather than protection of specific use; DO criterion is the exception and is related to aquatic life-use protection (Texas Commission on Environmental Quality, 2000).

${ }^{4}$ Statistically derived from 10 years of surface-water-quality monitoring data using 85 th percentile; used in the absence of established criteria to denote a concern.

${ }^{5}$ Assessed in support of aquatic life-use protection (Texas Commission on Environmental Quality, 2006); mg/kg = $\mu \mathrm{g} / \mathrm{g}$.

${ }^{6}$ Any metal greater than limit does not pass TCLP test; any metal less than limit passes TCLP test (Federal Register, 2007). For this study, used as screening tool; TCLP applies to hazardous waste.

Water-quality samples were collected during August 6-9, 2002 , at each RG/RB site as a single grab sample from the part of the river with the greatest volume of flow at an approximate depth of 1 foot below the water surface. Flow of the RG/RB at the IBWC streamflow-gaging station Rio Grande at Johnson Ranch near Castolon, Tex., and Santa Elena,
Chihuahua (08-3750.00), during the 4-day sampling period averaged 802 cubic feet per second, which is about 66 percent of the long-term (1936-2007) average flow of 1,216 cubic feet per second at the station (International Boundary and Water Commission, 2007) but about 150 percent of the average flow during the past 15 years (October 1992-September 2007) of 
536 cubic feet per second. Flow conditions during the sampling period are difficult to characterize relative to long-term conditions, as long-term conditions might be changing. Field properties of specific conductance, $\mathrm{pH}$, temperature, dissolved oxygen, and alkalinity were measured at each RG/RB site. The water-quality samples were collected and field properties were measured in accordance with the TCEQ "Surface Water Quality Monitoring Procedures, Volume 1: Physical and Chemical Monitoring Methods for Water, Sediment, and Tissue" (Texas Commission on Environmental Quality, 2003). These procedures are outlined in the Texas Clean Rivers Program (CRP) Rio Grande Basin Monitoring Quality Assurance Project Plan (International Boundary and Water Commission, 2001).

The water-quality samples were analyzed by the USIBWC CRP contract laboratories for selected constituents that include major ions; DS, TSS, and VSS; nutrients; and trace elements. Analytical methods used to analyze these constituents are documented by the Texas Commission on Environmental Quality (2003, Appendix D). Calcium was analyzed using U.S. Environmental Protection Agency (USEPA) method 200.7, and magnesium was analyzed using USEPA method 242.1. Chloride and sulfate concentrations were analyzed using USEPA method 300.0. DS, TSS, and VSS were analyzed using USEPA methods 160.1, 160.2, and 160.4, respectively. Nitrite plus nitrate was analyzed using USEPA method 353.3. Nitrogen, as ammonia, was analyzed using USEPA method 350.1. Total phosphorus was analyzed using USEPA method 365.3, and orthophosphorus was analyzed using USEPA method 300.0. The water-quality samples for trace elements were collected using clean techniques with pre-cleaned bottles, equipment, and instructions provided by the USIBWC CRP contract laboratory following USEPA methods 1669 and 1631c (Albion Environmental, 2003a, b, c; U.S. Environmental Protection Agency, 1995b). Concentrations of aluminum, barium, cadmium, chromium, copper, nickel, lead, silver, and zinc were analyzed by inductively coupled plasma-mass spectrometry according to USEPA methods 1638/200.8 (Albion Environmental, 2003c; U.S. Environmental Protection Agency, 1995a). Mercury concentrations in water were analyzed using USEPA methods 1669 and 1631C (Albion Environmental, 2003a; U.S. Environmental Protection Agency, 2001); selenium concentrations were analyzed using USEPA method 1632 (Albion Environmental, 2003b; U.S. Environmental Protection Agency, 1996). Speciation was not determined for any trace elements and all trace element concentrations were total dissolved values, with the exception of mercury and selenium. In the case of mercury and selenium, the water samples were analyzed for total recoverable concentrations.

Field blank samples for trace elements were collected from three sites (table 4, at end of report). Most of the constituents analyzed in the field blanks were less than the laboratory reporting level (LRL). Although the field blank collected from the Rio Grande at Santa Elena Crossing site had a detectable mercury concentration of 0.0003 microgram per liter $(\mu \mathrm{g} / \mathrm{L})$, the concentration was less than the LRL of $0.0005 \mu \mathrm{g} / \mathrm{L}$ and likely does not indicate contamination of mercury analyses from the sampling procedure (Albion Environmental, 2003a). Zinc was detected in the field blank samples collected from the Rio Grande above Lajitas and Rio Grande at Santa Elena Crossing sites. The zinc concentration in the Lajitas field blank, $3.58 \mu \mathrm{g} / \mathrm{L}$, was greater than the concentration measured in many of the environmental samples (table 4). This high field blank concentration indicates that the other samples with zinc concentrations less than $18 \mu \mathrm{g} / \mathrm{L}$ might have been biased because of potential contamination during sampling (Albion Environmental, 2003c). Two duplicate samples were collected from main-stem sites and one duplicate sample was collected from a tributary site. Results of duplicate sampling are listed in table 4.

Streambed-sediment-quality samples were collected from the RG/RB main-stem and tributary sites following guidelines established for the USGS National Water-Quality Assessment Program (Shelton and Capel, 1994) (table 5, at end of report). Fine-grained surficial sediment samples were collected and composited from two to five wetted natural depositional zones along the river bank at each selected site to yield a representative sample. The fine-grained surficial sediment was collected using a Teflon spoon, scoop, or spatula and latex-free synthetic polymer gloves to minimize contamination. Once collected, these samples were composited and sieved through a 63-micrometer mesh nylon-sieve cloth held in a plastic frame to obtain a sample composed of the silt fraction with particles that were less than 63 micrometers in diameter. The samples then were stored in air-tight containers and chilled until analysis. The streambed-sediment-quality samples were analyzed for 44 major and trace elements by the USGS Geologic Discipline in Denver, Colo., using the analytical methods discussed in Arbogast (1996), Briggs and Meier (1999), and Taggart (2002). The predominant major ions (calcium, magnesium, potassium, sodium), as well as phosphorous and aluminum, are reported by the USGS Geologic Discipline in percent of total bottom material, whereas most other trace elements are reported in micrograms per gram. Duplicate samples were collected from two main-stem sites and results are listed in table 5.

Mine-tailing-quality samples were collected from areas in and adjacent to accessible abandoned mines and mine processing areas (table 6, at end of report). Similar to the procedures used to collect streambed-sediment samples, two to five mine-tailing samples were collected at each site using Teflon scoops and latex-free synthetic polymer gloves and then composited to form a representative sample from each minetailing site. Samples were collected from unweathered tailings beneath the surface of the tailings pile. The mine-tailing samples were analyzed by the TCEQ Environmental Laboratory in Houston, Tex., for 25 inorganic ions and trace elements using USEPA Method 200.7 (U.S. Environmental Protection Agency, 2002). The TCEQ laboratory that analyzed the samples reported all constituents in milligrams per kilogram, including the predominant major ions (calcium, magnesium, 
potassium, sodium) as well as phosphorous and aluminum. For quality assurance, laboratory method blanks were analyzed with environmental mine-tailing samples. All method blanks for the mine tailings yielded constituent concentrations less than the LRLs. Laboratory method blank surrogates also were analyzed with the environmental samples. The actual recoveries for all the analytes ranged from 99.7 to 104 percent, which is within the laboratory-reported acceptable range of 85 to 115 percent.

The Toxicity Characteristic Leaching Procedure (TCLP), using USEPA SW-846 analytical method 1311, was designed to simulate the leaching of contaminants in landfills (Environment, Health and Safety Online, 2007; U.S. Environmental Protection Agency, 1992). The TCLP was applied to determine the leaching potential for 10 trace elements from 14 samples collected at 11 abandoned mine and mine-tailing sites in the United States and Mexico (fig. 2, table 7, at end of report). The TCLP extraction is done by subjecting the material to a simulated landfill leachate; concentrations in the simulated leachate are reported in milligrams per liter. Acetic acid is used as the extraction fluid because it is the major component of typical municipal landfill leachates. After extraction, the resulting liquid from the study samples were analyzed for antimony, arsenic, barium, beryllium, cadmium, chromium, lead, nickel, selenium, and silver (table 7). For screening purposes only, the results were compared with TSWQS criteria and screening levels to indicate how readily metals contained in the mine tailings might be leached into the surrounding area (table 3 ). The higher the TCLP concentration, the higher the potential for that particular constituent to be leached from its source.

\section{Quality of Stream Water}

The water chemistry of 12 samples collected from the RG/RB main-stem and tributary sites in the study area provides insight into the salinity and solute transport of major ions and trace elements in the RG/RB and its tributaries. The water chemistry also can provide information on the relative effects of the abandoned mines and mine processing sites on the water in the basin. Ions and trace elements, if present in sufficient concentrations, might have an adverse effect on the quality of water needed to maintain human health and protect aquatic life. A number of constituents sampled for were detected at fairly low concentrations, many less than the LRL, indicating a relatively low probability for adversely affecting the water quality in the region. Other constituents that were detected frequently at relatively high concentrations throughout the study area are discussed in the following sections.

\section{Salinity and Suspended Solids}

Salinity differs from one watershed to another and is highly dependent on the underlying rock type. Arid areas in the region tend to concentrate salts in the soil because of the high rate of evaporation. Runoff from these areas carries salts into streams or reservoirs. Salinity commonly is increased by irrigation return flows or by domestic wastewater discharges. Reduced flows and high evaporation during drought conditions also can increase salinity. Increased salinity can make a water body unsuitable for aquatic species not tolerant of brackish water, for use in agriculture (livestock and crops), and for use as a drinking-water source.

Elevated salinity in streams, especially in the more arid parts of the region, results from both natural and human activities. In general, rainwater has a very low salinity. However, as runoff flows over land, the slightly acidic nature of rainwater can dissolve and release ions from soil and rock, causing an increase in the salinity (Hem, 1992). The most common ions (inorganic salts) are bicarbonate, calcium carbonate, chloride, magnesium, potassium, sodium, and sulfate. The relative contribution of these ions to the salinity in a solution can be determined directly by analysis of the water for these constituents or DS, or indirectly by field measurements of specific conductance, $\mathrm{pH}$, and alkalinity (Hem, 1992).

Calcium concentration can be an important factor in the water chemistry of streams as it forms chemical bonds with carbonates. If sufficient quantities of calcium carbonate are present in minerals, such as limestones, the acidic water derived from mine openings and tailings can be buffered by calcium carbonate. Calcium concentrations ranged from 67 to 490 milligrams per liter $(\mathrm{mg} / \mathrm{L})$, with a median concentration of $290 \mathrm{mg} / \mathrm{L}$ (fig. 4; table 4). The lowest calcium concentrations were in samples collected from the tributary sites (fig. 5). The highest calcium concentrations were in samples collected from RG/RB main-stem sites from Santa Elena Crossing downstream to La Linda, a section of the river known for perennial springs that contribute ground water to the base flow of the river. The higher calcium concentrations in the main-stem samples indicate that flow in the RG/RB is diluting runoff from the tributaries and buffering the river from more acidic water.

Sulfate is a common constituent in mine drainage. The sulfate concentrations from the RG/RB main-stem and tributary sites ranged from 102 to $796 \mathrm{mg} / \mathrm{L}$, with a median concentration of $268 \mathrm{mg} / \mathrm{L}$ (fig. 4; table 4). The TSWQS general-use protection criterion for sulfate, $570 \mathrm{mg} / \mathrm{L}$ (table 3), was exceeded only at the Rough Run Draw site (fig. 5) in the upper part of the study area. The lowest sulfate concentrations were in samples from the San Carlos Creek and Arroyo del Fortino sites in Mexico, both of which are spring-fed creeks. In general, relatively high sulfate concentrations were in the upper part of the study area from the Lajitas to Woodson's sites, with the highest sulfate concentrations from tributaries draining the Terlingua mining district (figs. 2, 5). The higher sulfate concentrations in the upper part of the basin might be an indication of dissolution of minerals such as cinnabar (mercury sulfide) from mercury mining areas.

Chloride concentrations ranged from 3 to $225 \mathrm{mg} / \mathrm{L}$, with a median concentration of $51 \mathrm{mg} / \mathrm{L}$ (fig. 4; table 4). 


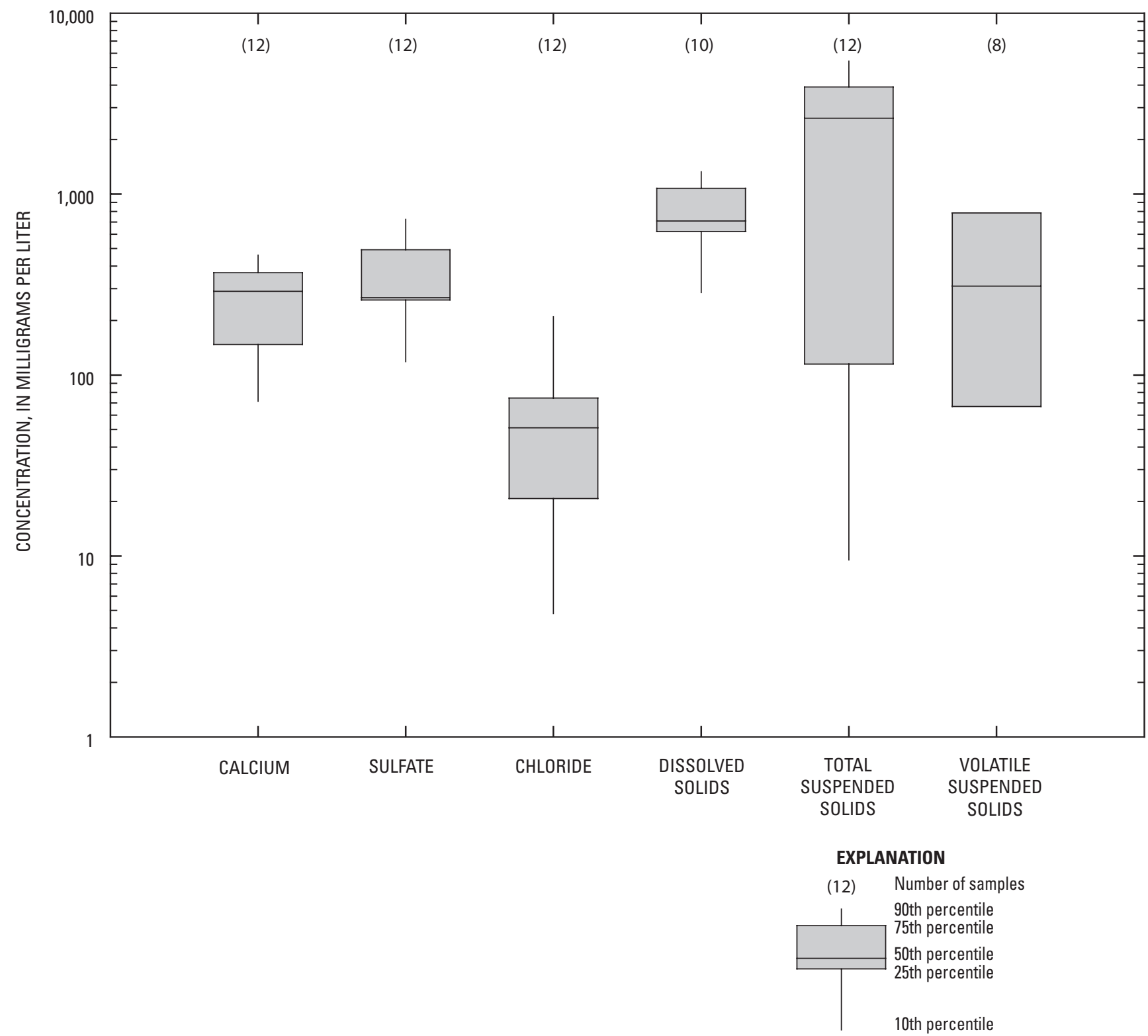

Figure 4. Distribution of concentrations of calcium, sulfate, chloride, dissolved solids, total suspended solids, and volatile suspended solids in water samples collected August 6-9, 2002, in the Big Bend area of the United States and Mexico.

All concentrations were less than the TSWQS general-use protection criterion for chloride of $300 \mathrm{mg} / \mathrm{L}$ (table 3). Except for the samples collected at the Lajitas and Woodson's sites, the chloride concentrations at all other sites were $80 \mathrm{mg} / \mathrm{L}$ or less and were fairly consistent throughout the study area (fig. 5).

The DS concentration is used as an indication of salinity. Consistent with previous USGS reports, in this report freshwater is defined as water with DS concentration of $1,000 \mathrm{mg} / \mathrm{L}$ or less, slightly saline water is defined as water with DS concentration between 1,000 to $3,000 \mathrm{mg} / \mathrm{L}$, and saline water is defined as water with DS concentration equal to or greater than 3,000 mg/L (Winslow and Kister, 1956; Nickerson, 2006). All water samples were fresh to slightly saline, with DS concentrations ranging from 255 to $1,350 \mathrm{mg} / \mathrm{L}$ and a median concentration of $710 \mathrm{mg} / \mathrm{L}$ (fig. 4; table 4). The TSWQS general-use protection criterion for DS in segment 2306 is $1,500 \mathrm{mg} / \mathrm{L}$ (table 3 ). DS concentrations of all water samples were less than the TSWQS criterion.

The higher DS concentrations (slightly saline) were in samples collected from the Lajitas, Rough Run Draw, and Terlingua Creek sites in the upper part of the study area downstream from the Terlingua mining district (figs. 2, 6). The lowest DS concentration (the freshest water) was at the Santa Elena Crossing site. The lower concentration might indicate a freshwater source, possibly ground-water seepage from springs to the main-stem $\mathrm{RG} / \mathrm{RB}$ in this area, that is diluting DS concentrations. 


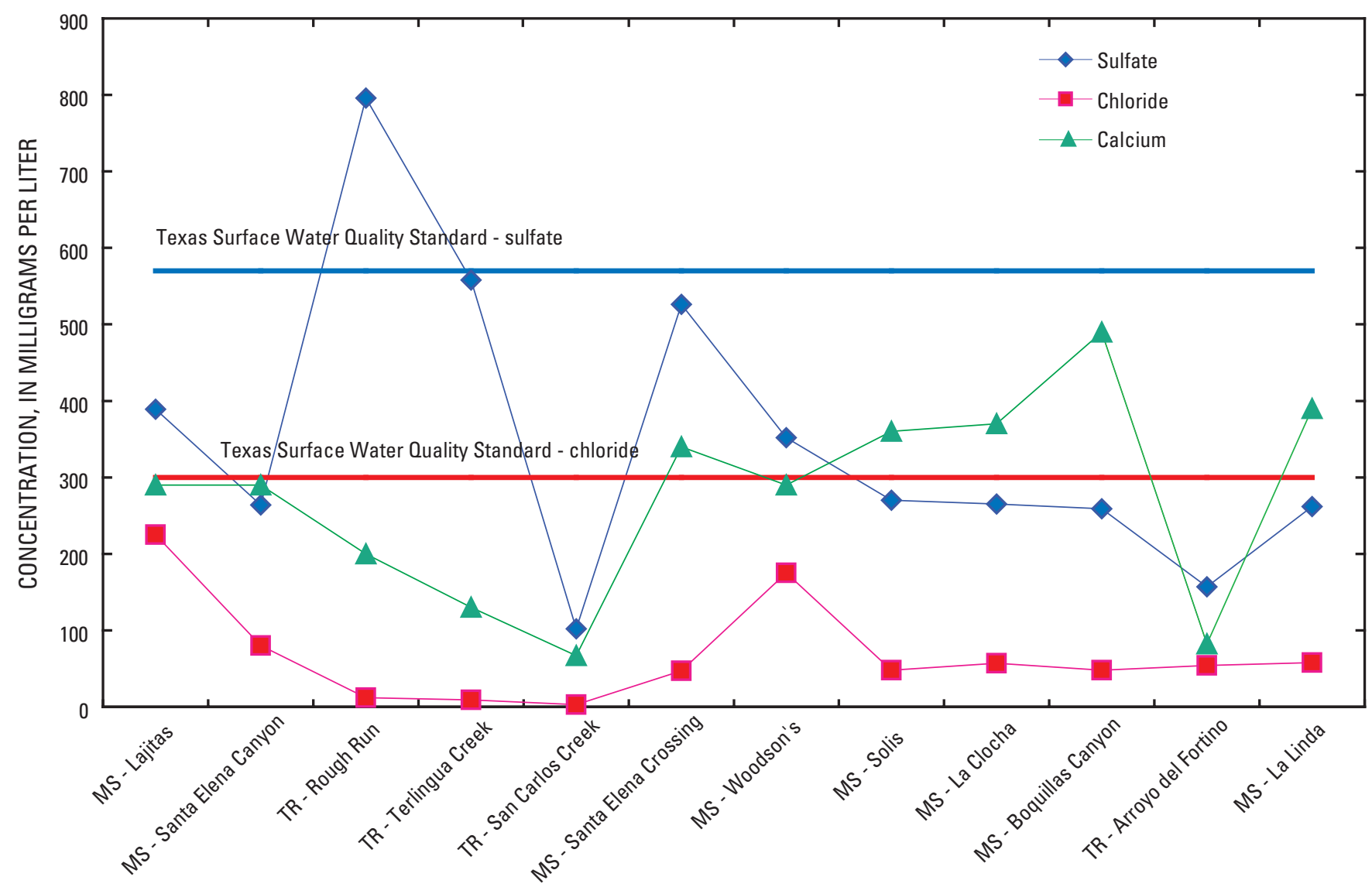

SAMPLE IDENTIFIER

Figure 5. Concentrations of calcium, sulfate, and chloride in water samples collected August 6-9, 2002, from Rio Grande/Río Bravo main-stem (MS) and tributary (TR) sites (downstream order) in the Big Bend area of the United States and Mexico.

TSS is a measure of both organic and inorganic suspended solids in water (Texas Commission on Environmental Quality, 2003). TSS concentrations were highest in water samples collected from the main-stem RG/RB and lowest in samples collected from the tributaries (fig. 6; table 4). The TSS concentration ranged from 5 to $5,550 \mathrm{mg} / \mathrm{L}$ with a median concentration of $2,265 \mathrm{mg} / \mathrm{L}$. The highest TSS concentrations were in the samples collected from the Solis, La Clocha, and Boquillas Canyon main-stem RG/RB sites. Higher TSS concentrations correspond to lower DS concentrations in the main-stem RG/RB section from the Santa Elena Crossing site downstream to the La Linda site. During flows higher than those during August 6-9, 2002, there is probably a greater input of TSS and sediment from the tributaries.

VSS is the portion of TSS that is lost after the sample is ignited (Texas Commission on Environmental Quality, 2003, Appendix B, Glossary). The VSS represents the organic portion of the TSS that is volatilized. VSS concentrations were variable, ranging from 3 to $920 \mathrm{mg} / \mathrm{L}$, with a median concentration of $310 \mathrm{mg} / \mathrm{L}$ (fig. 6; table 4). Similar to the results for TSS, the higher VSS concentrations were from main-stem RG/RG samples and probably are related to the higher sediment load carried by the river. In the lower part of the study area from the Woodson's site to Boquillas Canyon site, the main-stem VSS concentrations were similar to the DS concentrations.

\section{Trace Elements}

For most mining areas, water released from the mines, dumps, or mine tailings tends to carry high trace element concentrations at the source that are roughly in proportion to acidity of the water. Such waters evolve to a higher $\mathrm{pH}$ and lower trace element concentrations as mine waters are diluted and neutralized by natural processes in streams (Nash, 2003). The $\mathrm{pH}$ of water determines the solubility (amount that can be dissolved in the water) and the biological availability (amount that can be used by aquatic life) of chemical constituents and trace elements. In the case of trace elements, the degree to which they are soluble determines their toxicity. Metals tend to be more toxic at lower $\mathrm{pH}$ values because they are more soluble. All sample pHs were moderate (relatively neutral), ranging from 7.3 to 8.3 , with a median of 7.5 (table 4 ). The pHs were within the range of 6.5 to 9.0 specified by the TSWQS general-use protection criterion for segment 2306 (Texas Commission on Environmental Quality, 2006). The 


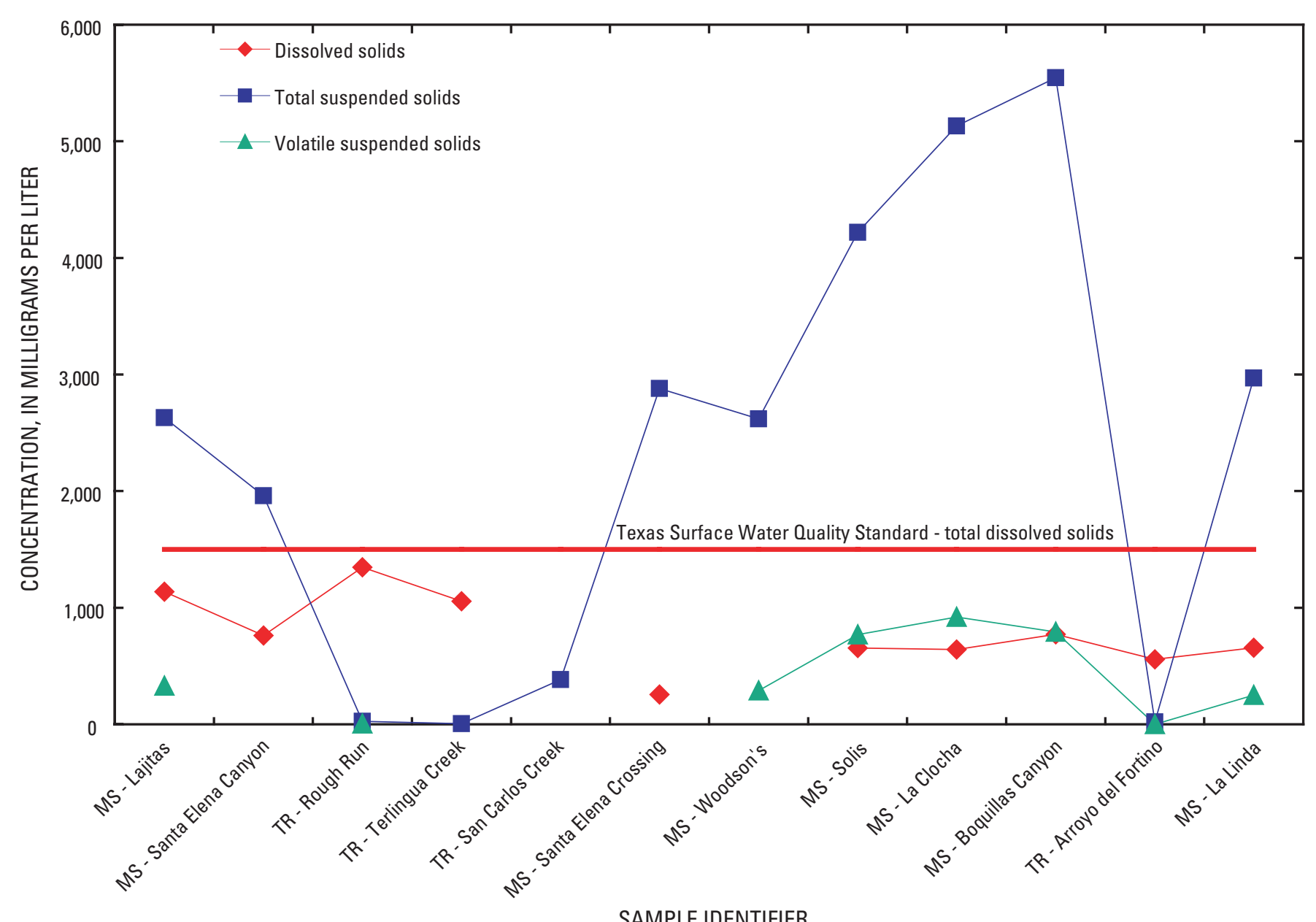

Figure 6. Concentrations of dissolved solids, total suspended solids, and volatile suspended solids in water samples collected August 6-9, 2002, from Rio Grande/Río Bravo main-stem (MS) and tributary (TR) sites (downstream order) in the Big Bend area of the United States and Mexico.

majority of $\mathrm{pH}$ values measured in segment 2306 of the RG/RB during 1999-2004 were in the specific range, which is typical of surface-water bodies in this part of Texas (C.M. Kolbe, Texas Commission on Environmental Quality, written commun., 2006). The $\mathrm{pH}$ of 8.3 in the sample from San Carlos Creek downstream from La Esperanza (San Carlos) Mine probably is the result of a greater proportion of ground water in the flow, as San Carlos Creek is partially spring-fed. The moderate $\mathrm{pHs}$ indicate that waters in the RG/RB and its tributaries are well mixed, diluted, and buffered with respect to the solubility of trace elements from mining areas.

Aluminum is a trace element that is commonly in rocks in the Big Bend area and that can be toxic to plants and aquatic life (Pais and Jones, 1997). The TSWQS acute criterion for the protection of aquatic life for aluminum is $991 \mu \mathrm{g} / \mathrm{L}$ (table 3). Aluminum concentrations in the water samples ranged from 2.2 to $545 \mu \mathrm{g} / \mathrm{L}$, with a median concentration of $126 \mu \mathrm{g} / \mathrm{L}$ (fig. 7; table 4). The higher aluminum concentrations were measured in the main-stem RG/RB sites in the upper part of the watershed that drains the Terlingua mining district in the United States and the San Carlos Creek in Mexico (figs. 2, 8). All aluminum concentrations were less than the TSWQS acute criterion.

Barium is a common trace element in the Earth's crust and frequently found in combination with sulfate and carbonate (Pais and Jones, 1997). Although generally chemically inactive, it can become highly toxic to animals and humans when combined to form soluble salts such as barium sulfate. The barium in water samples ranged from 47.7 to $172 \mu \mathrm{g} / \mathrm{L}$ with a median concentration of $110 \mu \mathrm{g} / \mathrm{L}$ (fig. 7; table 4). All barium concentrations were less than the 2,000 $\mu \mathrm{g} / \mathrm{L}$ TSWQS human health criterion for public water supply use (table 3 ). The higher barium concentrations were in the main-stem RG/RB samples as compared to the tributary samples (fig. 8).

Cadmium is a naturally occurring element in the earth's crust and usually is found combined with other elements as a mineral (Pais and Jones, 1997). All soils and rocks, as well as coal and other fossil fuels and mineral fertilizers, contain 


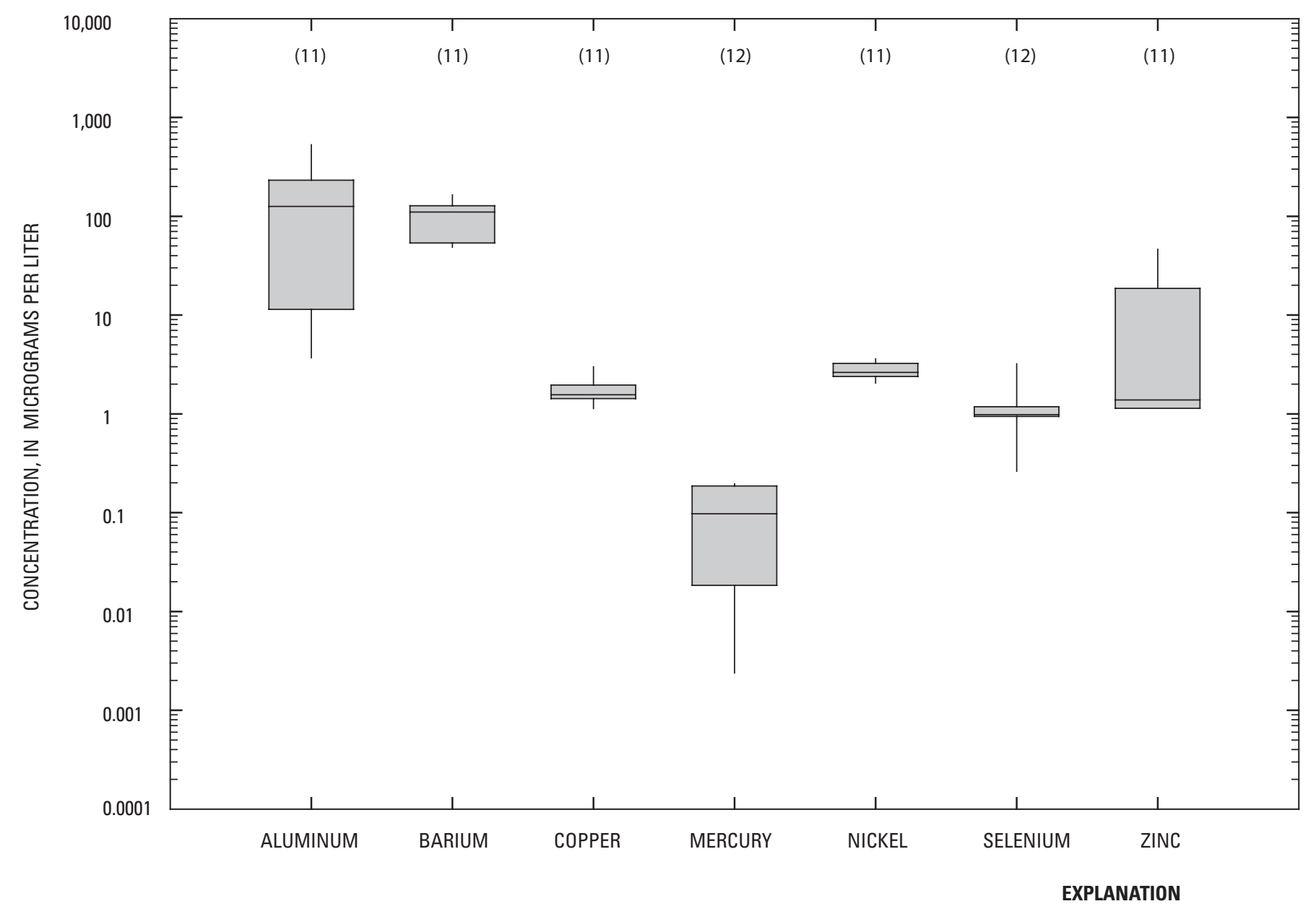

(11) Number of samples

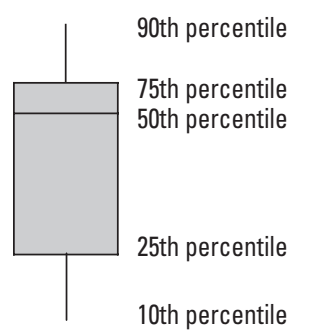

Figure 7. Distribution of concentrations of aluminum, barium, copper, mercury, nickel, selenium, and zinc in water samples collected August 6-9, 2002, in the Big Bend area of the United States and Mexico.

some trace amounts of cadmium (Pais and Jones, 1997). From a health perspective, cadmium is a carcinogen and is introduced into the atmosphere from mining, industry applications, and burning of coal and household waste (International Boundary and Water Commission, 2004). Sources of cadmium in water are the metal plating industry, industrial effluent, and municipal wastewater treatment plant effluent. Cadmium does not break down in the environment and can be persistent in water. Cadmium often bioaccumulates in tissue, thus contributing to a high potential for acute and chronic toxicity to aquatic life (International Boundary and Water Commission, 2004).
There were few detectable cadmium concentrations in the water samples (table 4). Only the samples collected from San Carlos Creek and Arroyo del Fortino had detectable cadmium concentrations. San Carlos Creek drains the San Carlos Mine, and Arroyo del Fortino drains the Puerto Rico Mine (fig. 2). The remaining samples contained less than the LRL for cadmium of $0.1 \mu \mathrm{g} / \mathrm{L}$, and all samples contained less than the TSWQS criterion for aquatic life-use protection and for human health (table 3 ).

Chromium is a naturally occurring element in rocks, plants, animals, volcanic dust, and gases (Pais and Jones, 1997). The chemistry of chromium is complex, and its toxicity 


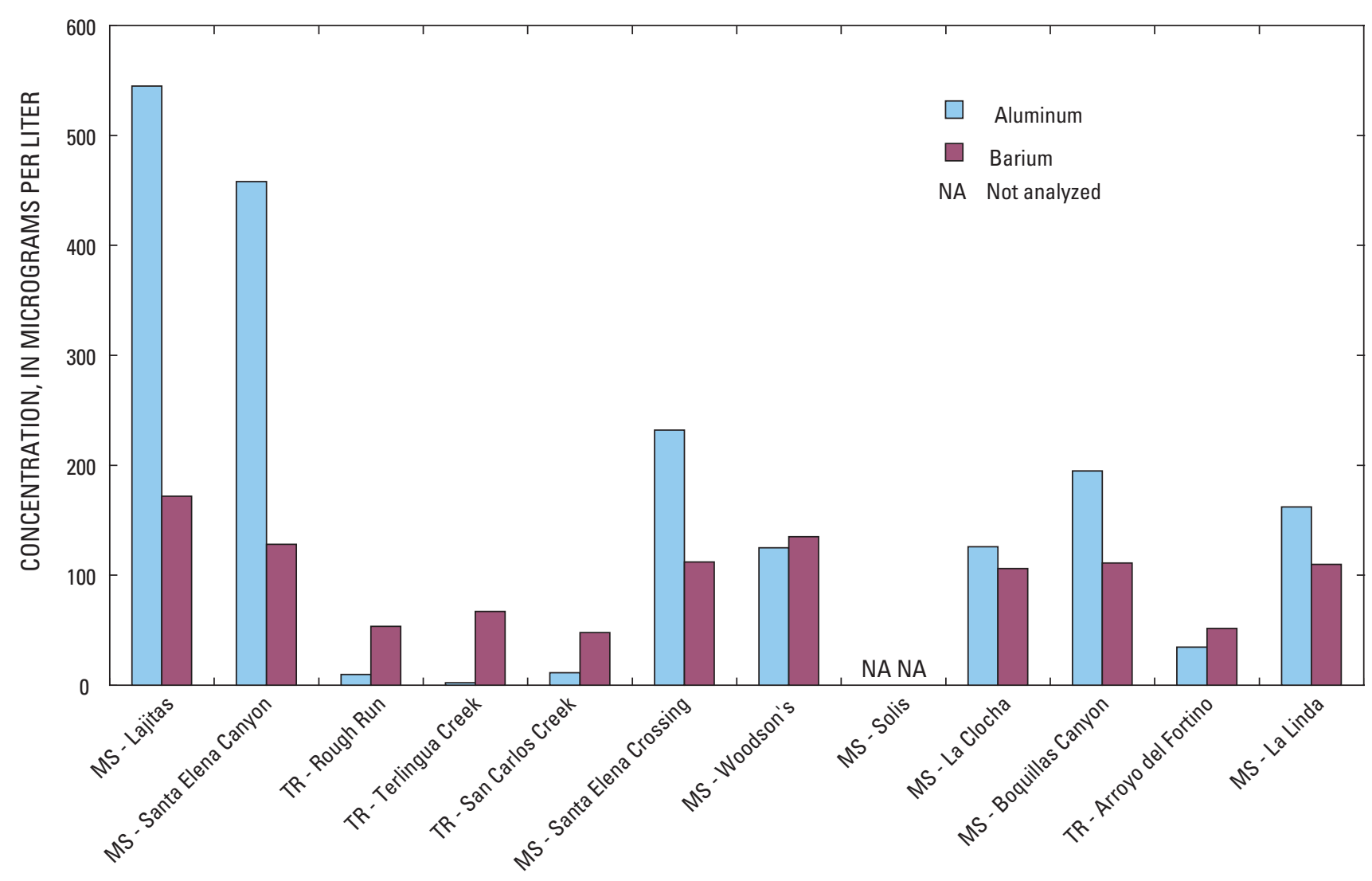

SAMPLE IDENTIFIER

Figure 8. Concentrations of aluminum and barium in water samples collected August 6-9, 2002, from Rio Grande/Río Bravo main-stem (MS) and tributary (TR) sites (downstream order) in the Big Bend area of the United States and Mexico.

is based on its valence state, which affects its solubility and reactivity. Chromium (III) occurs naturally and is an essential nutrient required by humans, and chromium (VI) and chromium (0) generally are produced by industrial processes (International Boundary and Water Commission, 2004). In addition, the deposition of airborne chromium also can be an important nonpoint source of chromium in surface water.

Chromium is both a carcinogen and a mutagen (Pais and Jones, 1997). A small amount dissolves in water, and the remainder settles to the bottom of the stream channel. Soluble chromium compounds can remain in water for years before settling to the bottom. Chromium does not accumulate in fish tissue but is very persistent in water. Chromium is more toxic in soft water than in hard water. Chromium (III) has a moderate acute toxicity and high chronic toxicity to aquatic life, and chromium (VI) has high acute and chronic toxicity to aquatic life (International Boundary and Water Commission, 2004).

The absorption of chromium is influenced by the presence of chelating agents and metals, particularly zinc and iron (Pais and Jones, 1997).

Detectable chromium concentrations were only in water samples from the Lajitas, Terlingua Creek, and Arroyo del Fortino sites (table 4). The samples from Lajitas and Terlin- gua Creek drain the Terlingua mining district. The Arroyo del Fortino site receives drainage from the area of the Puerto Rico Mine. Similar to cadmium, all samples had chromium concentrations less than the TSWQS criterion for acute and chronic aquatic life-use protection and for human health (table 3).

Copper is common in rocks and soils but generally is fairly immobile in soils (Pais and Jones, 1997). Rainfall might be a substantial source of copper to the aquatic environment in industrial and mining areas (International Boundary and Water Commission, 2004). Copper can easily be precipitated and readily interacts with both organic and inorganic substances (Pais and Jones, 1997). Van Metre and others (1997) documented an upward trend in copper concentrations in a sediment core in the RG/RB arm of Amistad Reservoir. Copper also is an essential micronutrient that can become toxic to plants when the tissue concentration exceeds 20 to 30 milligrams per kilogram (mg/kg) (Pais and Jones, 1997).

Copper concentrations also were relatively low with little variation among samples for all sites, ranging from 1.11 to $3.03 \mu \mathrm{g} / \mathrm{L}$, with a median concentration of $1.56 \mu \mathrm{g} / \mathrm{L}$ (fig. 7; table 4). The highest copper concentrations were in samples from the tributary sites, Rough Run Draw and Arroyo del Fortino (fig. 9), that drain the Study Butte Mine and the Puerto 


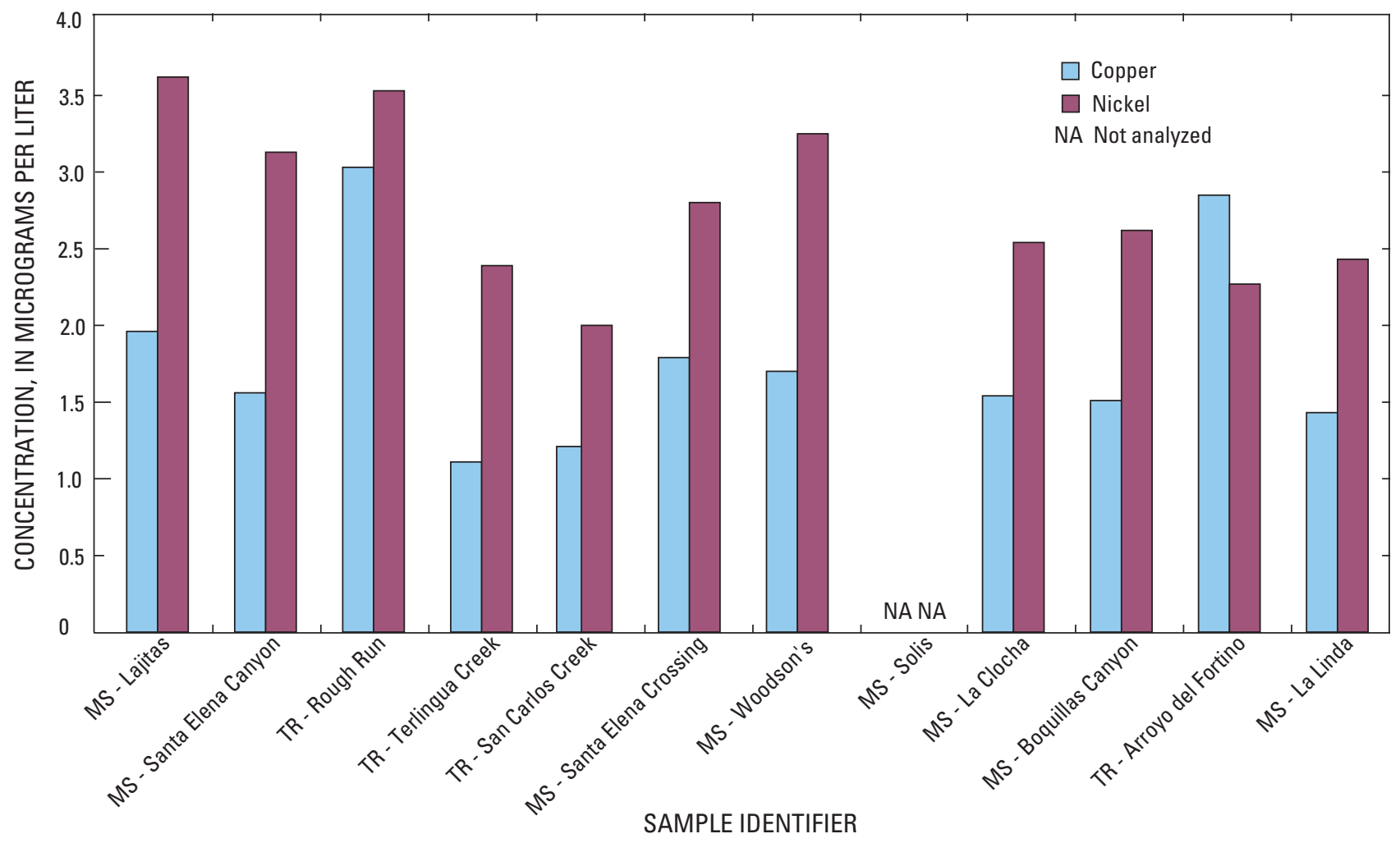

Figure 9. Concentrations of copper and nickel in water samples collected August 6-9, 2002, from Rio Grande/Río Bravo main-stem (MS) and tributary (TR) sites (downstream order) in the Big Bend area of the United States and Mexico.

Rico Mine, respectively. All copper concentrations were less than the TSWQS criterion for acute and chronic aquatic lifeuse protection (table 3 ).

Nickel, one of the most common trace elements, is in all soils and can occur from weathering of rocks, deposition from precipitation, and surface-water runoff (Pais and Jones, 1997). Nickel is a common trace element in air and is removed from the atmosphere by rain or snow. Most nickel becomes attached to soil or sediment particles. Common sources of nickel include the burning of coal and other fossil fuels, electroplating, and smelting. Nickel is a known carcinogen with a high acute toxicity and high chronic toxicity in aquatic life, although it is not known to bioaccumulate in fish tissue (International Boundary and Water Commission, 2004).

Similar to copper concentrations, nickel concentrations were relatively low, ranging from 2 to $3.62 \mu \mathrm{g} / \mathrm{L}$ with a median concentration of $2.62 \mu \mathrm{g} / \mathrm{L}$ (table 4). The highest nickel concentrations were in samples from Lajitas to Woodson's main-stem sites and from Rough Run Draw tributary site (fig. 9). All nickel concentrations were less than the TSWQS criterion for acute and chronic aquatic life-use protection (table 3).

Mercury can occur naturally in the environment, or can be introduced in runoff from urban and industrial sources and municipal and industrial discharges. Mercury also can enter the environment through atmospheric deposition. Mercury occurs in several forms, ranging from elemental to dissolved organic and inorganic. Certain microorganisms have the ability to convert the organic and inorganic forms to highly toxic methyl and dimethyl mercury (Pais and Jones, 1997; Texas Commission on Environmental Quality, 2006). This methylation process has made all forms of mercury highly hazardous to the environment (International Boundary and Water Commission, 2004).

Mercury was detected in all water samples collected from the RG/RB main-stem and tributary sites. The mercury concentration ranged from 0.0007 to $0.198 \mu \mathrm{g} / \mathrm{L}$, with a median concentration of $0.0975 \mu \mathrm{g} / \mathrm{L}$ (fig. 7; table 4). Mercury concentrations in all samples, except those from the tributary sites at Terlingua Creek and Arroyo del Fortino, were greater than the TSWQS human health criterion for fish consumption $(0.0122 \mu \mathrm{g} / \mathrm{L})$, but all concentrations were considerably less than the criteria for acute and chronic aquatic life-use protection (table 3 ). The highest mercury concentrations were measured in samples from the Lajitas, Woodson's, Solis, La Clocha, and Boquillas Canyon main-stem sites (fig. 10). The concentrations were lowest in samples from the tributary sites and from the Santa Elena Canyon and Santa Elena Crossing main-stem sites. The relatively low mercury concentration at the Santa Elena Crossing site might be the result of mixing of $\mathrm{RG} / \mathrm{RB}$ water with ground water from springs in the area.

Most of the higher mercury concentrations can be related linearly to the TSS concentration (fig. 11); two of the 


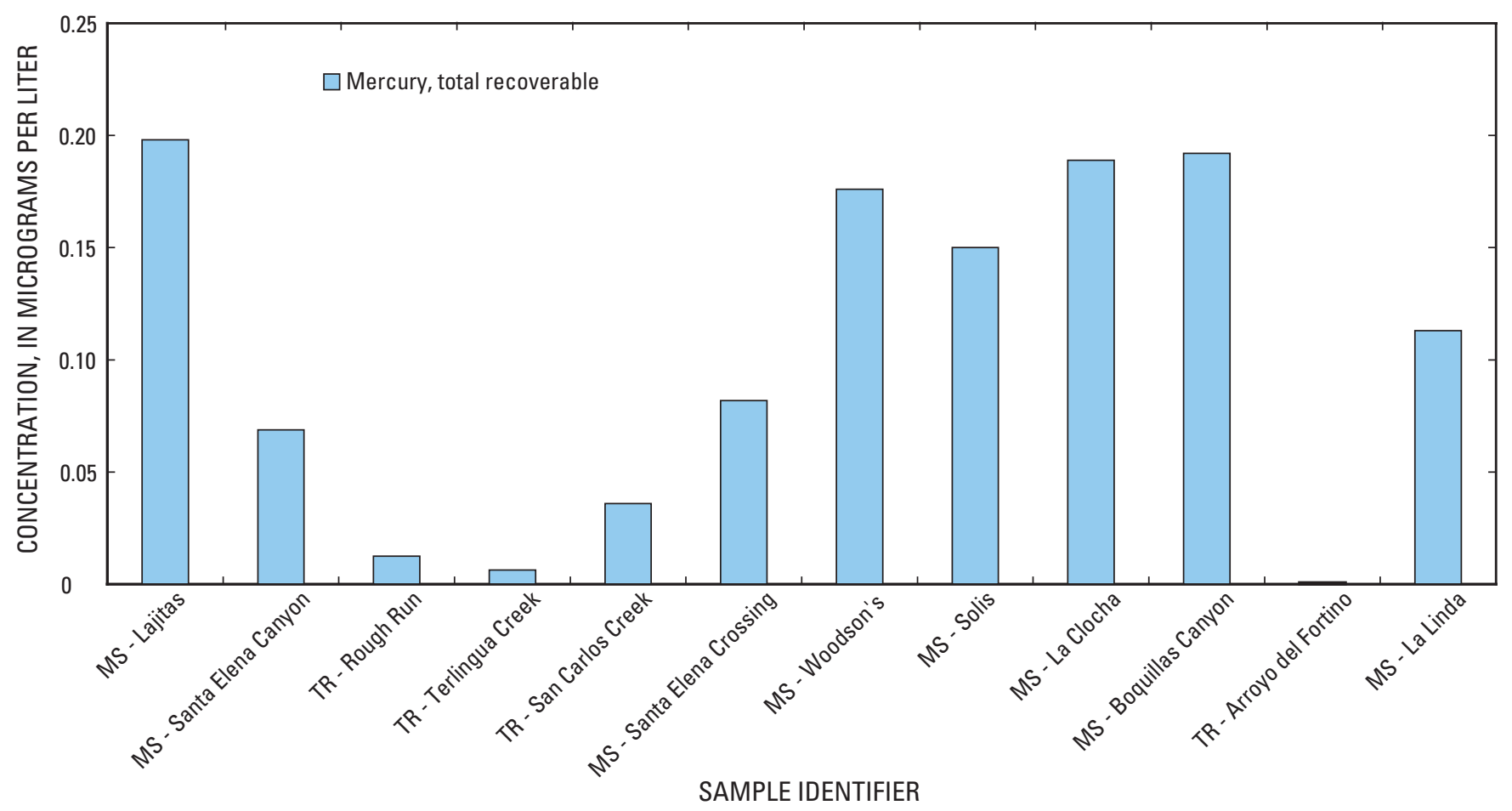

Figure 10. Concentration of mercury in water samples collected August 6-9, 2002, from Rio Grande/Río Bravo main-stem (MS) and tributary (TR) sites (downstream order) in the Big Bend area of the United States and Mexico.

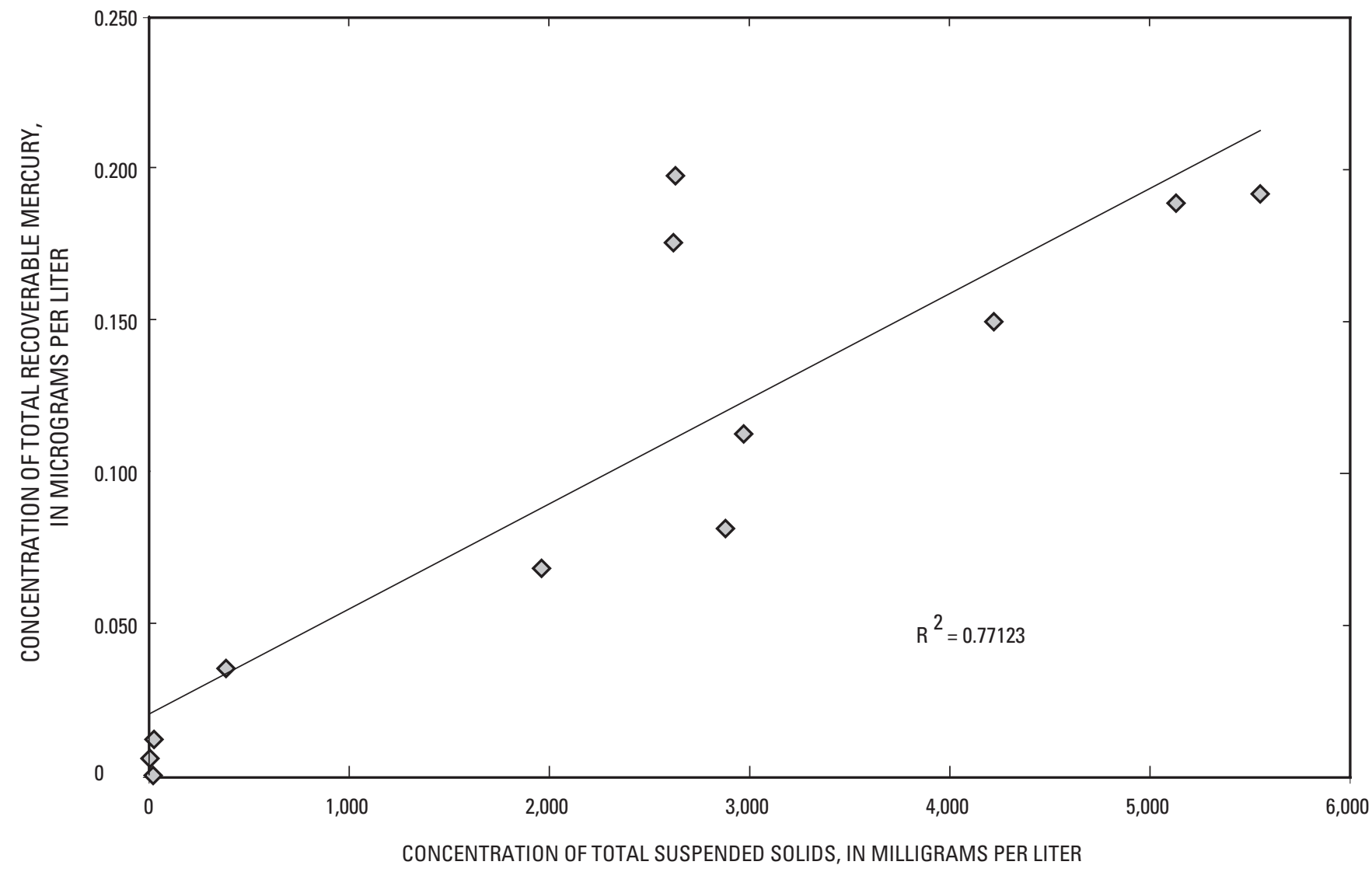

Figure 11. Relation of concentrations of total recoverable mercury to total suspended solids for water samples collected August 6-9, 2002, from Rio Grande/Río Bravo main-stem and tributary sites in the Big Bend area of the United States and Mexico. 
samples (Lajitas and Woodson's) appear to be outliers, that is, exceptionally high concentrations relative to the corresponding TSS concentrations. The high mercury concentrations in these two samples might indicate that the sites are receiving mercury from a nearby source. The source of mercury in water throughout the study area, however, does not seem to be solely abandoned mines and mine-tailing areas. Gray and others (2006) reported that the hot, arid climate in the area limited the process of mercury methylation and the transference of mercury and methyl-mercury from the Study Butte mine site. During hot and dry periods, offsite movement of mercury into streams might be minimal. Mobilization processes associated with extreme runoff events could be important transport mechanisms for mercury mobilization (Horowitz and others, 2001). During extreme runoff events, offsite movement of mercury into streams and remobilization of sediment and tailings previously transported to stream channels might be substantial. Relatively high mercury concentrations are not only in the upper part of the basin near the Terlingua mining district where expected, but they also are distributed throughout the study area. The presence of relatively high concentrations throughout the study area might indicate multiple sources of mercury in water. Possible sources include point sources in the abandoned mining areas, nonpoint sources from the erosion of bedrock that provides trace elements to the stream sediment, and nonpoint-source atmospheric deposition of mercury from human activities (Van Metre and others, 1997).

Lead is carcinogenic and teratogenic (causes fetal malformation) and is considered a major contaminant (Pais and Jones, 1997; International Boundary and Water Commission, 2004). The USEPA has included lead in the list of probable human carcinogens (Group B2) (U.S. Environmental Protection Agency, 2004). Lead is a major constituent of more than 200 minerals, of which only three are sufficiently abundant to form mineral deposits (International Boundary and Water Commission, 2004). Lead is the least mobile of the metals, accumulating primarily on the land surface. Lead is introduced to the environment through atmospheric deposition by precipitation and fallout of lead dust, urban runoff, and industrial and municipal wastewater treatment plant discharges (International Boundary and Water Commission, 2004). The availability of lead in the soil is influenced by $\mathrm{pH}$ - an increase in $\mathrm{pH}$ of soil decreases the solubility of lead (Pais and Jones, 1997). Lead is not readily soluble in water and generally, concentrations in sediment are relatively low.

The dissolved lead concentrations generally were relatively low in all water samples except the San Carlos Creek sample, which had a concentration of $21 \mu \mathrm{g} / \mathrm{L}$ (table 4 ). Concentrations in five samples were less than the LRL of $0.10 \mu \mathrm{g} / \mathrm{L}$, and concentrations in the remaining samples from Lajitas, Santa Elena Canyon, Santa Elena Crossing, Boquillas Canyon, and Arroyo del Fortino ranged from 0.12 to $0.26 \mu \mathrm{g} / \mathrm{L}$. The most probable source of the high lead concentration in the San Carlos Creek sample is the nearby San Carlos Mine and associated tailings. The San
Carlos Mine, upstream in the San Carlos Creek watershed, was mined for economic quantities of iron, lead, silver, and zinc (table 1). The lead concentration detected in the San Carlos Creek sample was greater than the TSWQS chronic criterion for the protection of aquatic life $(8.1 \mu \mathrm{g} / \mathrm{L})$ and the human health criterion for fish consumption $(4.98 \mu \mathrm{g} / \mathrm{L})$ (table 3). Although the lead concentration was elevated, the high $\mathrm{pH}$ of 8.3 associated with alkaline soils in the area might result in relatively low solubility of lead from the mine tailings and thus minimize the amount of lead that is transported offsite.

Selenium generally is unaffected by water and increases in concentration when there is an associated increase in the clay content of a soil (Pais and Jones, 1997). The solubility of selenium generally is relatively low. However, on poorly drained or calcareous soils and arid soils where selenium concentrations in the soil are high, selenium might accumulate to sufficient levels in plants to pose a substantial hazard to grazing animals (Pais and Jones, 1997). The selenium concentration in the water samples ranged from 0.25 to 3.26 $\mu \mathrm{g} / \mathrm{L}$, with a median concentration of $0.98 \mu \mathrm{g} / \mathrm{L}$ (fig. 7; table $4)$. The higher selenium concentrations were measured in samples from the tributary sites Rough Run Draw and Terlingua Creek, downstream from the Terlingua mining district (fig. 12; table 4). Selenium concentrations for all analyzed samples were less than the TSWQS criteria for the protection of aquatic life and human health (table 3 ).

There were no detectable concentrations of dissolved silver in any of the water samples. Silver concentrations in all samples were less than the TSWQS criterion for the protection of aquatic life of $0.8 \mu \mathrm{g} / \mathrm{L}$ (table 3 ).

Zinc is one of the most common trace elements and occurs in air, soil, and water (Pais and Jones, 1997). Zinc is an essential dietary element present in all foods. Zinc, which is readily transported in most river systems, can be introduced to the environment by natural processes and by human activities such as mining, steel production, waste incineration, and burning of coal or other fossil fuels (International Boundary and Water Commission, 2004). Zinc is one of the most readily soluble of all the trace elements in soils (Pais and Jones, 1997) and is not a known carcinogen but can accumulate in fish and other organisms. Zinc has a fairly high bioaccumulation index and the mechanism of zinc toxicity to aquatic primary producers is an interference with phosphorylation reactions (Bates and others, 1982). The dissolved zinc concentration in the water samples varied greatly. The zinc concentrations in most samples were between 0.89 and $3.12 \mu \mathrm{g} / \mathrm{L}$. Highest concentrations of $18.6 \mu \mathrm{g} / \mathrm{L}$ or greater were in the samples from the San Carlos Creek, Santa Elena Crossing, and Arroyo del Fortino sites (fig. 7; table 4). A possible explanation for the high zinc concentration at the three sites is abandoned mine areas. The San Carlos Creek sample was collected downstream from the San Carlos Mine tailings, and the Arroyo del Fortino sample was collected downstream from the Puerto Rico Mine (fig. 2). All zinc concentrations were less than the TSWQS acute and chronic criteria for the protection of aquatic life (table 3 ). 


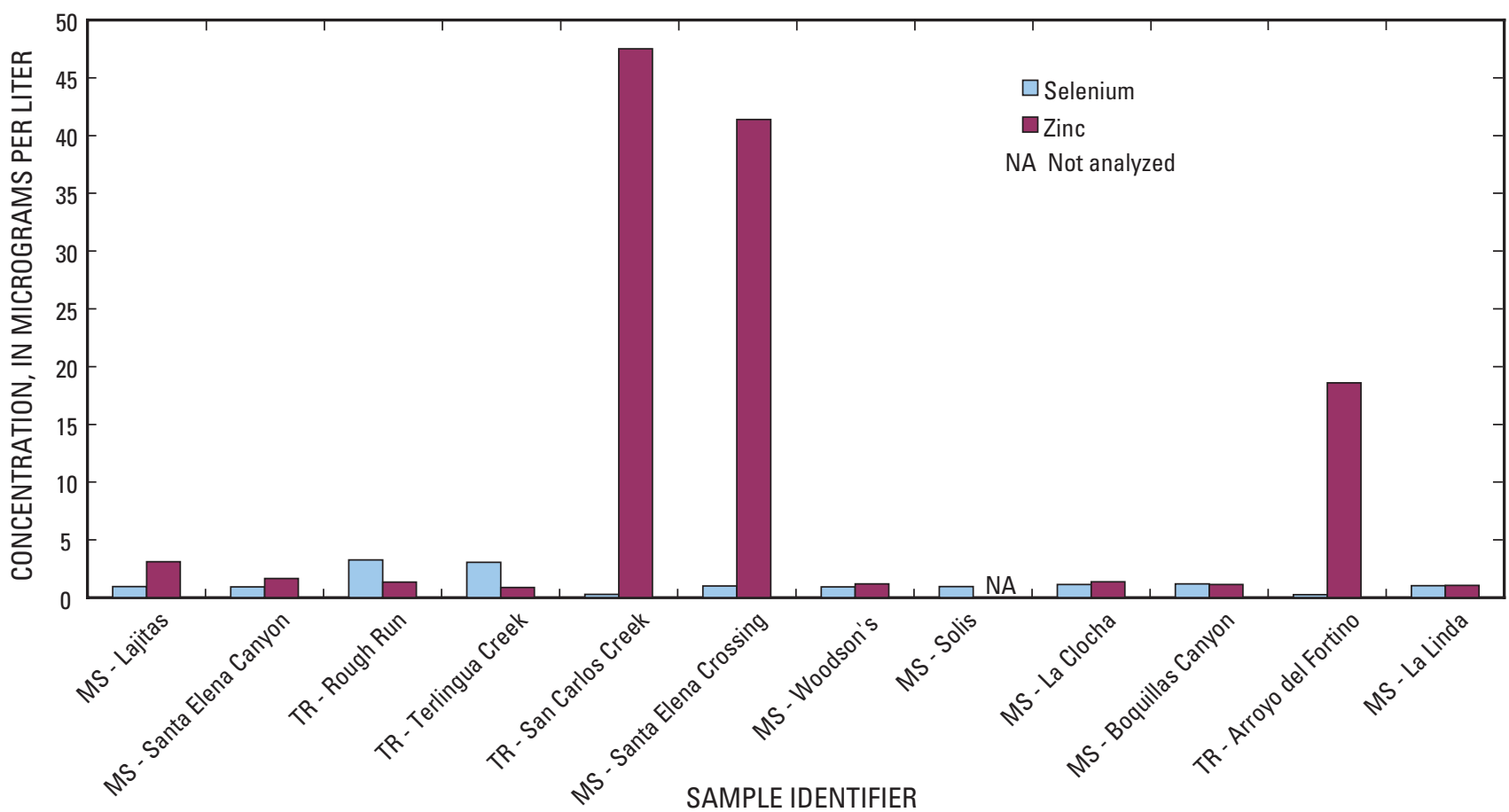

Figure 12. Concentrations of selenium and zinc in water samples collected August 6-9, 2002, from Rio Grande/Río Bravo main-stem (MS) and tributary (TR) sites (downstream order) in the Big Bend area of the United States and Mexico.

\section{Quality of Streambed Sediment}

The chemistry of streambed sediment is important because of its relation to the chemistry of water in the stream and, in turn, the effects of water chemistry on aquatic life. Streambed sediment is assessed in support of the aquatic lifeuse protection in Texas (Texas Commission on Environmental Quality, 2006). The aquatic life-use protection includes criteria for toxicity in water and sediment, sediment contaminants, biological communities, and in-stream habitat.

The percentages or concentrations of aluminum, antimony, arsenic, beryllium, bismuth, and cadmium were low at most sites throughout the study area, except for antimony, arsenic, and cadmium in streambed-sediment samples from the San Carlos Creek and Rough Run Draw sites (table 5). The percentage of aluminum in the streambed-sediment samples ranged from 1.7 to 6.7 for all samples, with a median of 5.9 (table 5). There was greater variability in the concentrations from the tributary sites. There is no TCEQ screening level for aluminum in sediment.

The antimony concentration ranged from 0.60 to 420 micrograms per gram $(\mu \mathrm{g} / \mathrm{g})$, with a median of $0.80 \mu \mathrm{g} / \mathrm{g}$ (fig. 13; table 5). All samples had detectable antimony concentrations. The highest concentrations were measured in the samples from Rough Run Draw and San Carlos Creek, which are downstream from the Study Butte Mine and the La Esperanza (San Carlos) Mine tailings, respectively (fig. 14). The San Carlos Creek sample concentration exceeded the TCEQ sediment screening level of $25 \mathrm{mg} / \mathrm{kg}(\mu \mathrm{g} / \mathrm{g})$ used to evalu- ate trace elements that can have an adverse ecological effect (table 3).

Arsenic is released to the environment from natural sources (volcanoes, erosion from mineral deposits) and also from anthropogenic sources (metal smelting, chemical production and use, coal and other fossil fuel combustion, waste disposal) (International Boundary and Water Commission, 2004). Arsenic is a carcinogen, dissolves in water, changes from one form to another, is persistent in water, and can accumulate in fish and shellfish tissue. Certain forms have high acute and chronic toxicity in aquatic life.

All samples had detectable arsenic concentrations, with concentrations ranging from 5.7 to $450 \mu \mathrm{g} / \mathrm{g}$ and a median of $8.3 \mu \mathrm{g} / \mathrm{g}$ (fig. 13; table 5). Similar to antimony, the highest arsenic concentrations were measured in samples from San Carlos Creek downstream from the San Carlos Mine and from Rough Run Draw downstream from the Study Butte Mine (fig. 14). Most of the arsenic concentrations, except in samples from San Carlos Creek and possibly Rough Run Draw, probably are representative of background sediment concentrations. The concentration of the San Carlos Creek sample $(450 \mu \mathrm{g} / \mathrm{g})$, however, is more than an order of magnitude greater than the other sample concentrations and likely is the result of mining activities in the area. The San Carlos Creek sample concentration exceeded the TCEQ screening level of $33 \mathrm{mg} / \mathrm{kg}(\mu \mathrm{g} / \mathrm{g})$ used to evaluate trace elements that can have an adverse ecological effect (table 3 ). The arsenic concentrations at all other sites were well below the screening level. 


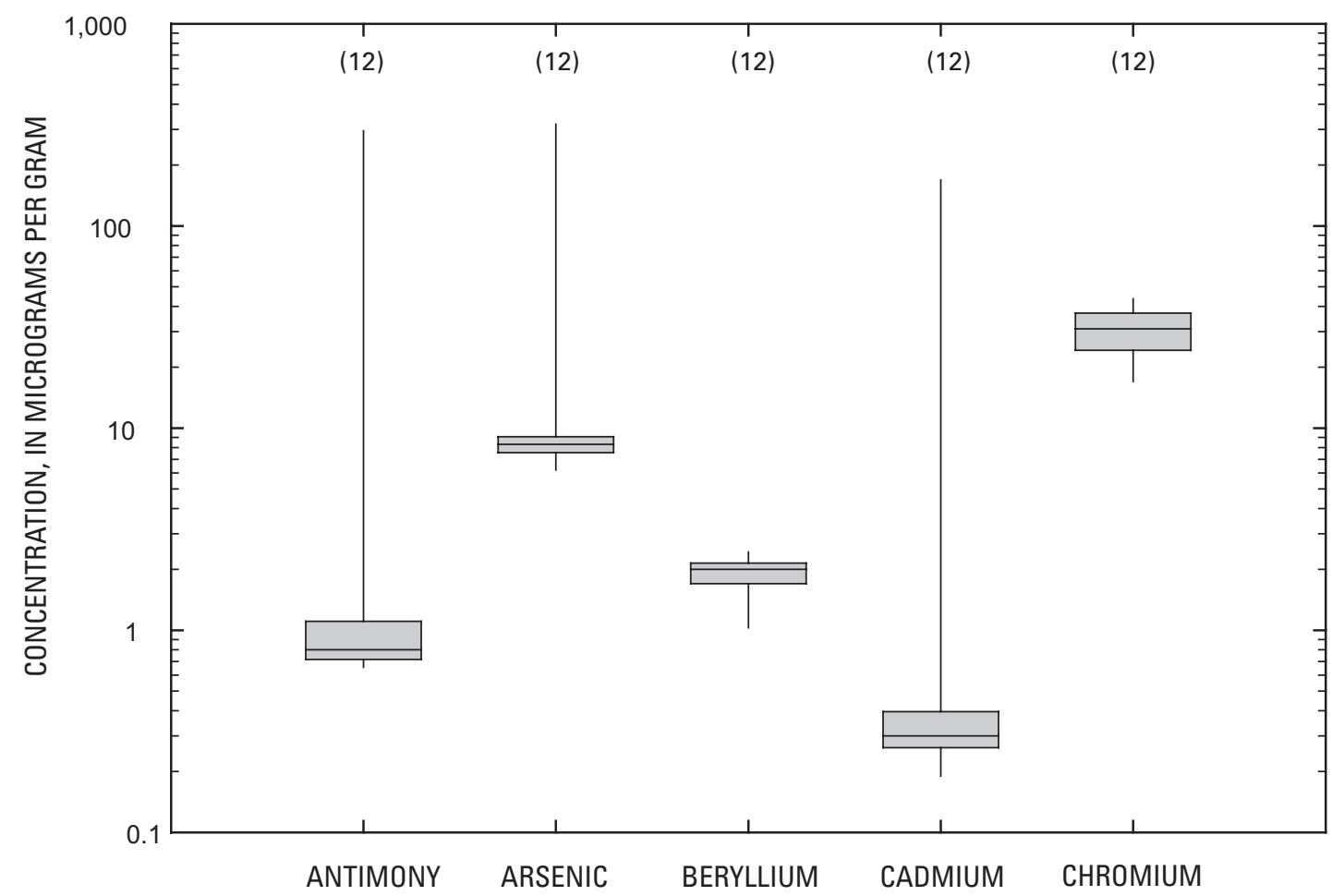

\section{EXPLANATION}

(12) Number of samples 90th percentile 75th percentile 50th percentile 25th percentile

10th percentile

Figure 13. Distribution of concentrations of antimony, arsenic, beryllium, cadmium, and chromium in streambed-sediment samples collected August 6-9, 2002, in the Big Bend area of the United States and Mexico.

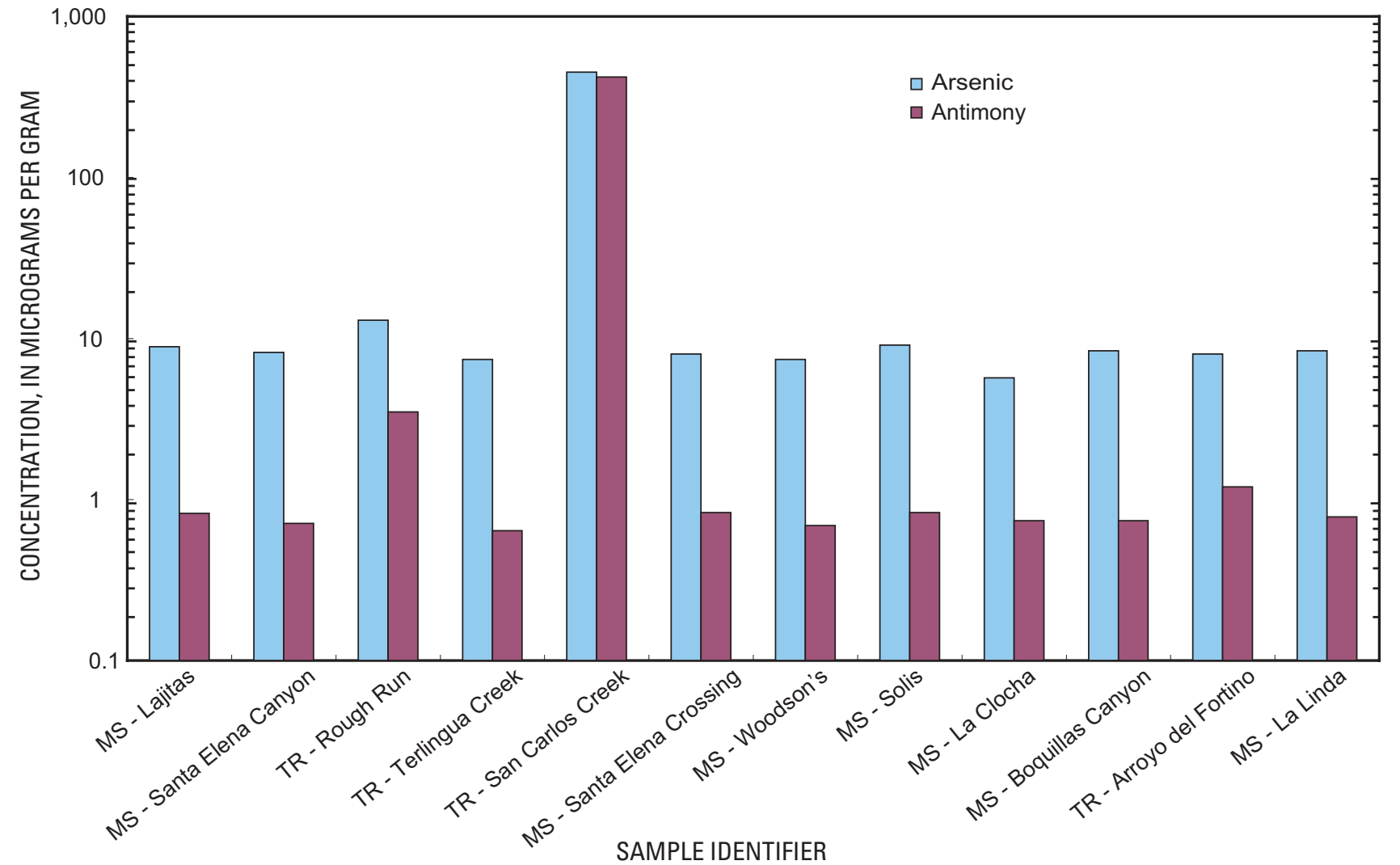

Figure 14. Concentrations of antimony and arsenic in streambed-sediment samples collected August 6-9, 2002, from Rio Grande/Río Bravo main-stem (MS) and tributary (TR) sites (downstream order) in the Big Bend area of the United States and Mexico. 


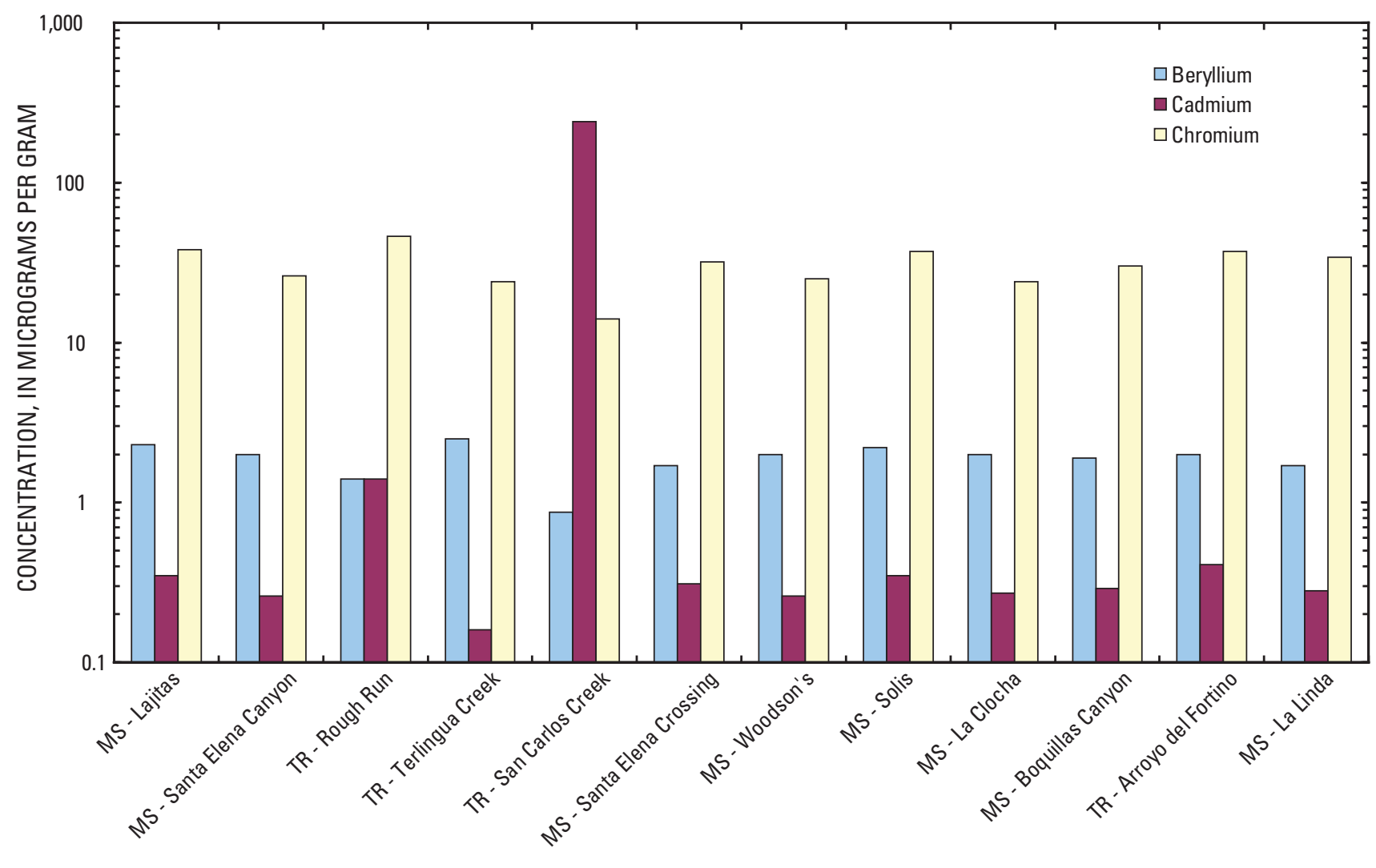

SAMPLE IDENTIFIER

Figure 15. Concentrations of beryllium, cadmium, and chromium in streambed-sediment samples collected August 6-9, 2002, from Rio Grande/Río Bravo main-stem (MS) and tributary (TR) sites (downstream order) in the Big Bend area of the United States and Mexico.

The beryllium concentration in the streambed-sediment samples ranged from 0.87 to $2.5 \mu \mathrm{g} / \mathrm{g}$, with a median of $2.0 \mu \mathrm{g} / \mathrm{g}$ (fig. 13; table 5). The highest beryllium concentrations were in samples from Lajitas, Terlingua Creek, and Solis (fig. 15). The beryllium concentrations vary over a fairly narrow range throughout the study area (fig.15) and probably are representative of regional background beryllium concentrations in streambed sediment. There is no TCEQ screening level for beryllium in streambed sediment.

The cadmium concentration ranged from 0.16 to 240 $\mu \mathrm{g} / \mathrm{g}$, with a median of $0.3 \mu \mathrm{g} / \mathrm{g}$ (fig. 13; table 5). Excluding the highest concentration, $240 \mu \mathrm{g} / \mathrm{g}$ in the San Carlos Creek sample, the sample concentrations ranged from 0.16 to 1.4 $\mu \mathrm{g} / \mathrm{g}$ (fig. 15). The next highest concentration $(1.4 \mu \mathrm{g} / \mathrm{g})$ was from Rough Run Draw, downstream from the Study Butte Mine. The cadmium concentration in the San Carlos Creek sample exceeded the TCEQ screening level for cadmium of $4.98 \mathrm{mg} / \mathrm{kg}(\mu \mathrm{g} / \mathrm{g})$ (table 3$)$. All other sample concentrations were less than the screening level.

Chromium concentrations ranged from 14 to $46 \mu \mathrm{g} / \mathrm{g}$, with a median of $31 \mu \mathrm{g} / \mathrm{g}$ (fig. 13; table 5). The highest chromium concentrations were in the samples from Lajitas and Rough Run Draw and the lowest in the sample from San Carlos Creek (fig. 15). Concentrations at all sites were less than the TCEQ sediment screening level for chromium of $111 \mathrm{mg} / \mathrm{kg}(\mu \mathrm{g} / \mathrm{g})$ (table 3$)$.

The copper concentration ranged from 12 to $49 \mu \mathrm{g} / \mathrm{g}$, with a median of $17 \mu \mathrm{g} / \mathrm{g}$ (fig. 16; table 5). The highest concentration was measured in the San Carlos Creek sample and the lowest concentration in the Santa Elena Canyon sample (fig. 17). All sample concentrations were less than the TCEQ sediment screening level for copper of $149 \mathrm{mg} / \mathrm{kg}(\mu \mathrm{g} / \mathrm{g})$ (table 3).

The mercury concentration ranged from 0.02 to 0.68 $\mu \mathrm{g} / \mathrm{g}$, with a median of $0.04 \mu \mathrm{g} / \mathrm{g}$ (fig. 16; table 5). The highest mercury concentrations were in samples from the Rough Run Draw tributary site downstream from the Terlingua Mining District and from the main-stem RG/RB La Linda site (fig. 17). The mercury concentrations at all other sites were $0.06 \mu \mathrm{g} / \mathrm{g}$ or less. The mercury concentrations at all sites were less than the TCEQ sediment screening level for mercury of $1.06 \mathrm{mg} / \mathrm{kg}(\mu \mathrm{g} / \mathrm{g})$ (table 3$)$.

The concentrations of molybdenum, nickel, selenium, and silver were relatively low in most samples (table 5). All nickel concentrations were less than the TCEQ sediment screening level of $48.6 \mathrm{mg} / \mathrm{kg}(\mu \mathrm{g} / \mathrm{g}$ ) (table 3). The one exception to the relatively low concentrations was the silver concentration in the San Carlos Creek sample of $24 \mu \mathrm{g} / \mathrm{g}$ that 


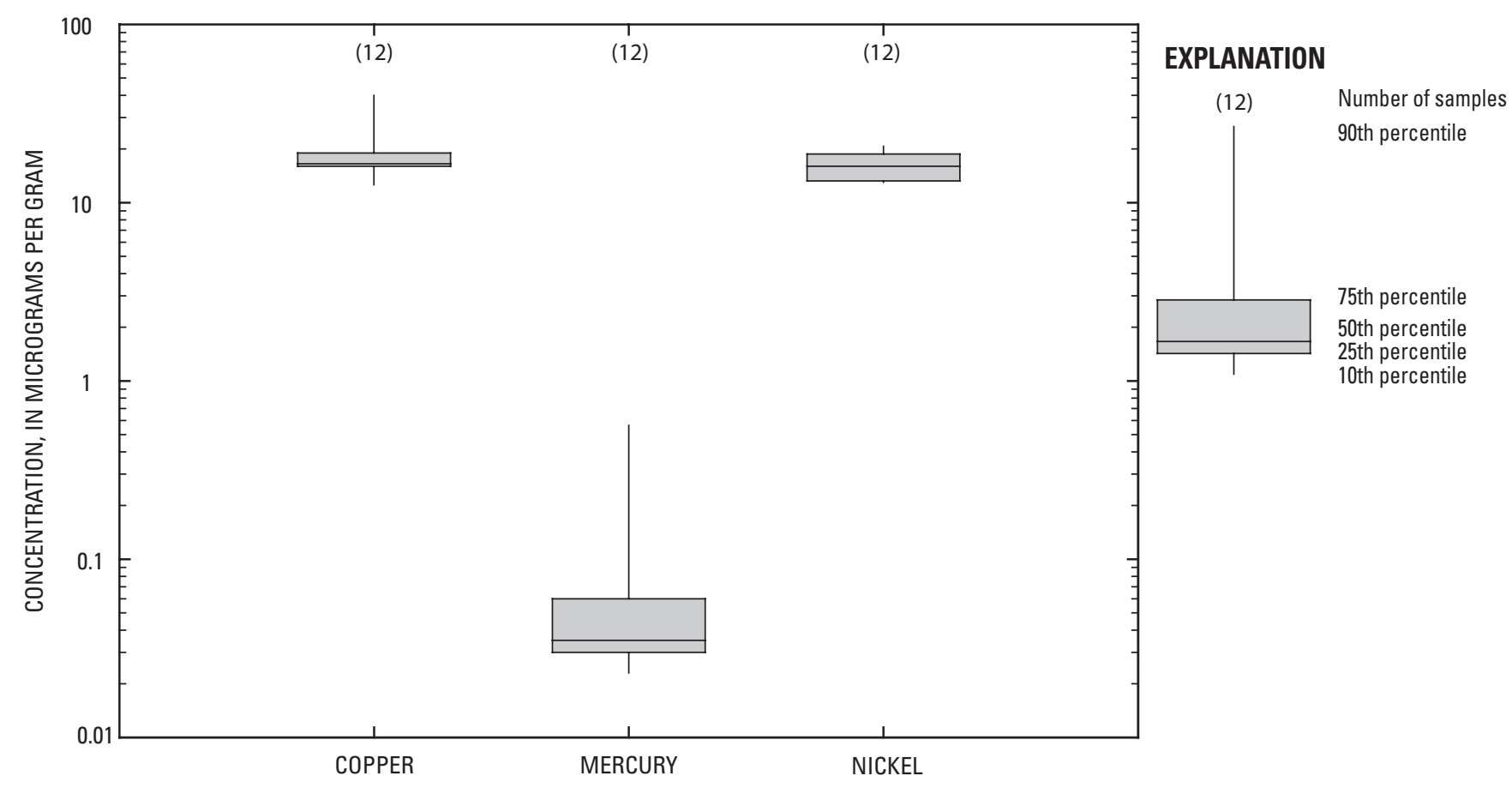

Figure 16. Distribution of concentrations of copper, mercury, and nickel in streambed-sediment samples collected August 6-9, 2002, in the Big Bend area of the United States and Mexico.

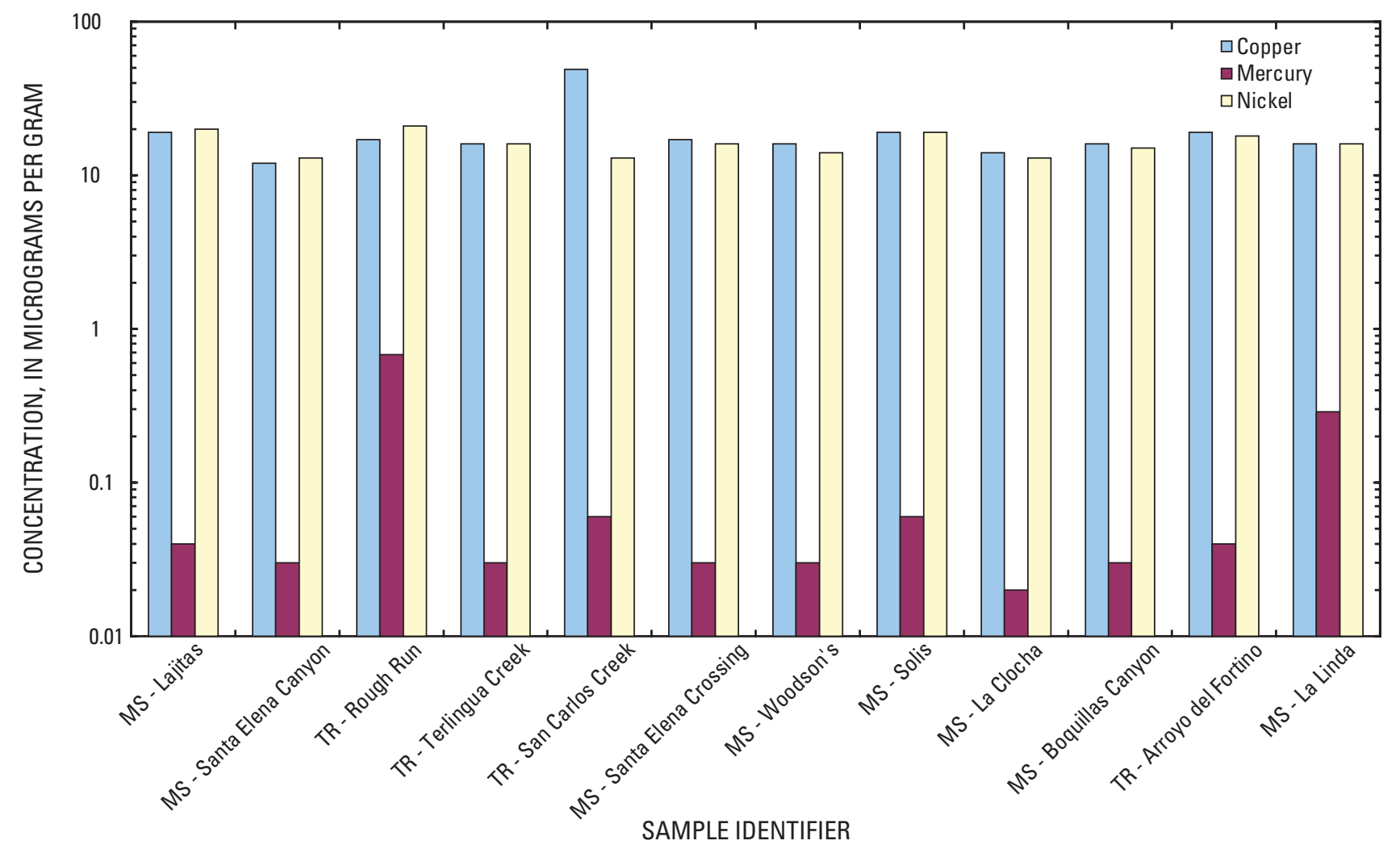

Figure 17. Concentrations of copper, mercury, and nickel in streambed-sediment samples collected August 6-9, 2002, from Rio Grande/ Río Bravo main-stem (MS) and tributary (TR) sites (downstream order) in the Big Bend area of the United States and Mexico. 


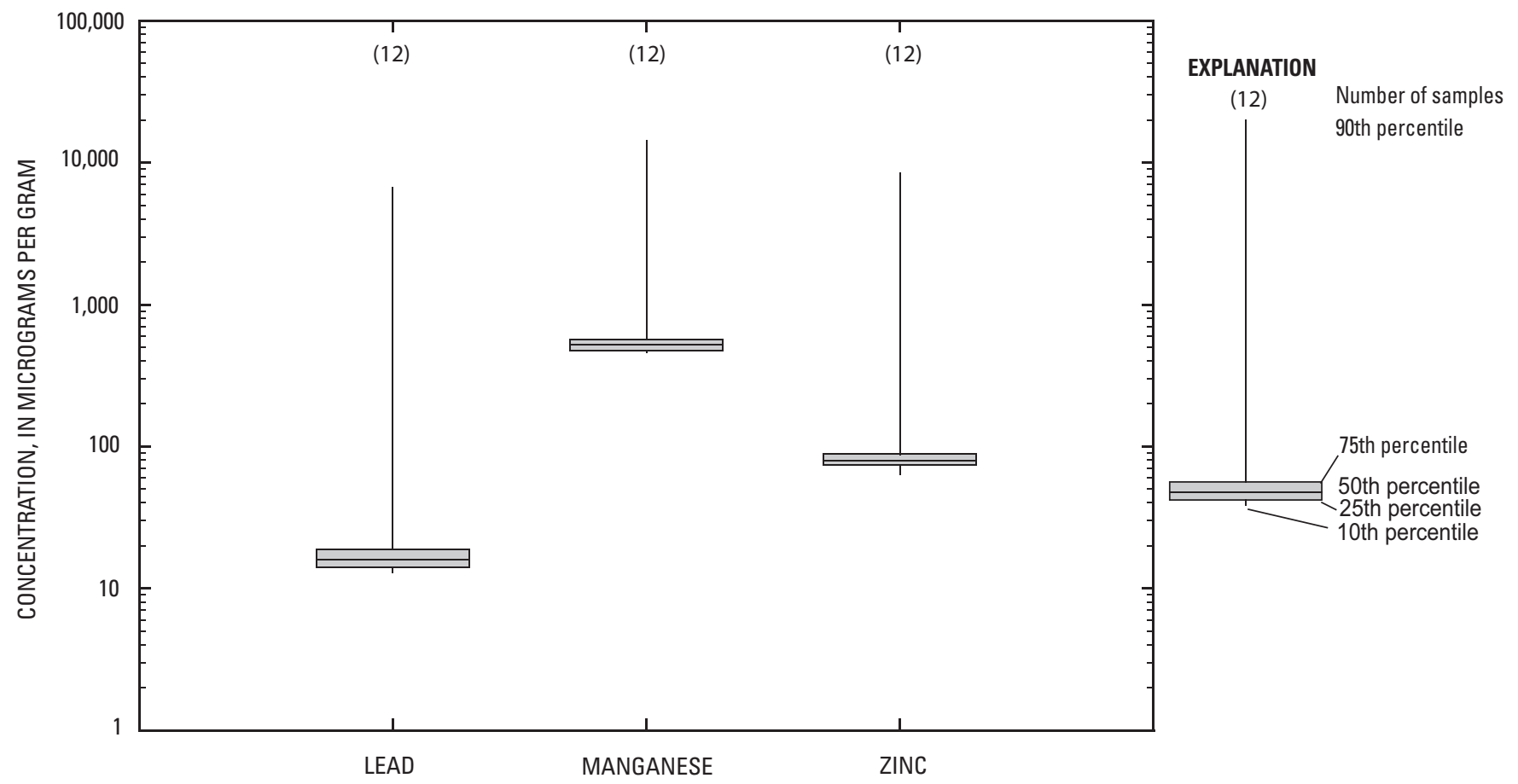

Figure 18. Distribution of concentrations of lead, manganese, and zinc in streambed-sediment samples collected August 6-9, 2002, from Rio Grande/Río Bravo main-stem and tributary sites in the Big Bend area of the United States and Mexico.

exceeded the TCEQ sediment screening level for silver of 2.2 $\mathrm{mg} / \mathrm{kg}(\mu \mathrm{g} / \mathrm{g})$ (table 3).

The lead concentration in streambed-sediment samples ranged from 13 to $9,500 \mu \mathrm{g} / \mathrm{g}$ (figs. 18, 19; table 5). Most lead concentrations were between 13 and $19 \mu \mathrm{g} / \mathrm{g}$, although the concentration at Rough Run Draw was $59 \mu \mathrm{g} / \mathrm{g}$ and at San Carlos Creek was 9,500 $\mu \mathrm{g} / \mathrm{g}$. Lead concentrations, except for the Rough Run Draw and San Carlos Creek samples, probably represent regional background concentrations. Only the San Carlos Creek sample concentration exceeded the TCEQ sediment screening level for lead of $128 \mathrm{mg} / \mathrm{kg}(\mu \mathrm{g} / \mathrm{g}$ ) (table 3).

The high lead concentration in the sample from San Carlos Creek indicates that some of the mining activities or mine tailing debris from the San Carlos Mine or other mines in the area have an effect on the sediment quality (fig. 19). The source of the elevated lead probably is the San Carlos Mine and tailings in the upper part of the San Carlos Creek watershed because of the large volume of mine tailings present and the size of the mining operation. Elevated concentrations of the same order of magnitude were not measured in any other samples collected in the study area. Because lead is the least mobile of the trace elements, however, there is probably not much movement of lead away from the mining site. The lead concentration in the Rough Run Draw sample is higher than the concentrations measured in the other samples but not nearly as high as the concentration measured in the San Carlos Mine sample. The Study Butte Mine is upstream from the Rough Run Draw sample site and is the likely lead source.
Manganese is one of the most abundant trace elements in the lithosphere and exists in soil over a wide range of oxidation states (Pais and Jones, 1997). The manganese concentration ranged from 460 to 20,000 $\mu \mathrm{g} / \mathrm{g}$ (fig. 18; table 5). Except for the concentration of $20,000 \mu \mathrm{g} / \mathrm{g}$ in the sample from San Carlos Creek, concentrations in all other samples ranged from 460 to $580 \mu \mathrm{g} / \mathrm{g}$ (fig. 19). The source of the elevated manganese most likely is the San Carlos Mine and mine tailings. There is not a TCEQ sediment screening level for manganese.

Thallium, tin, and vanadium were detected in several samples. The thallium concentration was less than the LRL of $1 \mu \mathrm{g} / \mathrm{g}$ at all sites except the San Carlos Creek site, where the thallium concentration was $2 \mu \mathrm{g} / \mathrm{g}$ (table 5). Tin concentrations also were fairly low, ranging from 1 to $3 \mu \mathrm{g} / \mathrm{g}$ in all samples except the San Carlos Creek sample (27 $\mu \mathrm{g} / \mathrm{g})$. The vanadium concentrations ranged from 47 to $97 \mu \mathrm{g} / \mathrm{g}$, with a median of $83 \mu \mathrm{g} / \mathrm{g}$. There is not a TCEQ sediment screening level for thallium, tin, or vanadium.

The zinc concentration in the streambed-sediment samples ranged from 62 to 12,000 $\mu \mathrm{g} / \mathrm{g}$ (fig. 18; table 5). Most streambed-sediment concentrations were similar in value (fig. 19) and less than $90 \mu \mathrm{g} / \mathrm{g}$ in all samples except the Rough Run Draw sample $(140 \mu \mathrm{g} / \mathrm{g})$ and San Carlos Creek sample $(12,000 \mu \mathrm{g} / \mathrm{g})$. The San Carlos Creek zinc concentration was several orders of magnitude greater than the other samples and was the only sample concentration that exceeded the TCEQ sediment screening level for zinc of $459 \mathrm{mg} / \mathrm{kg}(\mu \mathrm{g} / \mathrm{g})$ (table 3). The elevated zinc concentration at the San Carlos Creek site could be an issue because zinc has a fairly high 


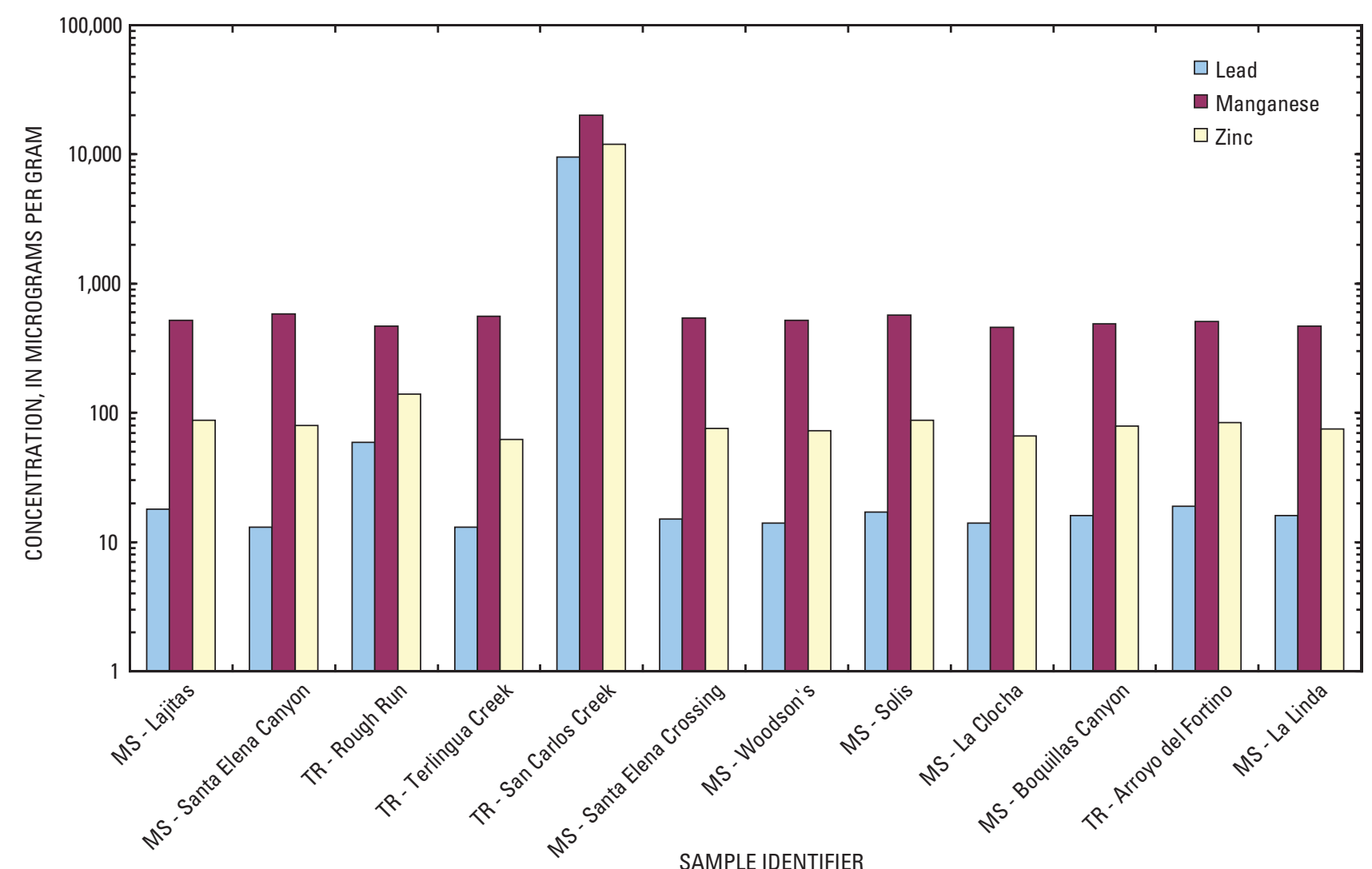

Figure 19. Concentrations of lead, manganese, and zinc in streambed-sediment samples collected August 6-9, 2002, from Rio Grande/ Río Bravo main-stem (MS) and tributary (TR) sites (downstream order) in the Big Bend area of the United States and Mexico.

bioaccumulation index and interferes with phosphorylation reactions (Bates and others, 1982).

The uranium concentration in the streambed-sediment samples ranged from 2.3 to $7.5 \mu \mathrm{g} / \mathrm{g}$, with a median of 2.7 $\mu \mathrm{g} / \mathrm{g}$ (table 5). The highest concentration was measured in the sample from San Carlos Creek. All other sample concentrations ranged from 2.3 to $3.0 \mu \mathrm{g} / \mathrm{g}$, a range that probably represents background conditions in the region.

The elevated concentrations of multiple trace elements in samples from the San Carlos Creek and Rough Run Draw sites indicate that San Carlos Creek, and probably Rough Run Draw, have been adversely affected by mining activities.

\section{Quality of Mine Tailings}

\section{Trace Elements}

All 25 major and trace elements analyzed, except selenium and thallium, were detected in one or more of the minetailing samples collected during the study (fig. 2; table 6). The aluminum concentration ranged from $4,920 \mathrm{mg} / \mathrm{kg}$ at the Study Butte Mine 2 site to $25,100 \mathrm{mg} / \mathrm{kg}$ at the Chisos/ Rainbow Mine 2 site, with a median of $9,425 \mathrm{mg} / \mathrm{kg}$ (table 6). Detectable antimony concentrations were measured in only three of 14 mine-tailing samples-Waldron, La Esperanza (San Carlos), and Boquillas Mines. These concentrations ranged from 43 to $109 \mathrm{mg} / \mathrm{kg}$, and all exceeded the TCEQ sediment screening level for antimony of $25 \mathrm{mg} / \mathrm{kg}$ (table 3 ). Arsenic was detected in 13 of 14 samples at concentrations ranging from 19 to $1,250 \mathrm{mg} / \mathrm{kg}$ (Boquillas) (fig. 20). Arsenic was not detected in the sample from Study Butte Mine 2. Detected arsenic concentrations exceeded the TCEQ sediment screening level for arsenic of $33 \mathrm{mg} / \mathrm{kg}$ (table 3 ) in all but two of the 13 samples.

Cadmium was detected at four sites, and detectable concentrations ranged from 24 to $409 \mathrm{mg} / \mathrm{kg}$ (table 6). All samples with detectable concentrations exceeded the TCEQ sediment screening level for cadmium of $4.98 \mathrm{mg} / \mathrm{kg}$ (table 3). The highest cadmium concentrations were in the samples from San Carlos, Tres Marias, and Puerto Rico Mines in Mexico.

Chromium was detected in all samples but at much lower concentrations than detected cadmium concentrations; chromium concentrations ranged from 2 to $23 \mathrm{mg} / \mathrm{kg}$ with a median of $11 \mathrm{mg} / \mathrm{kg}$. The highest concentrations were in the Chisos samples in the Terlingua mining district and the 


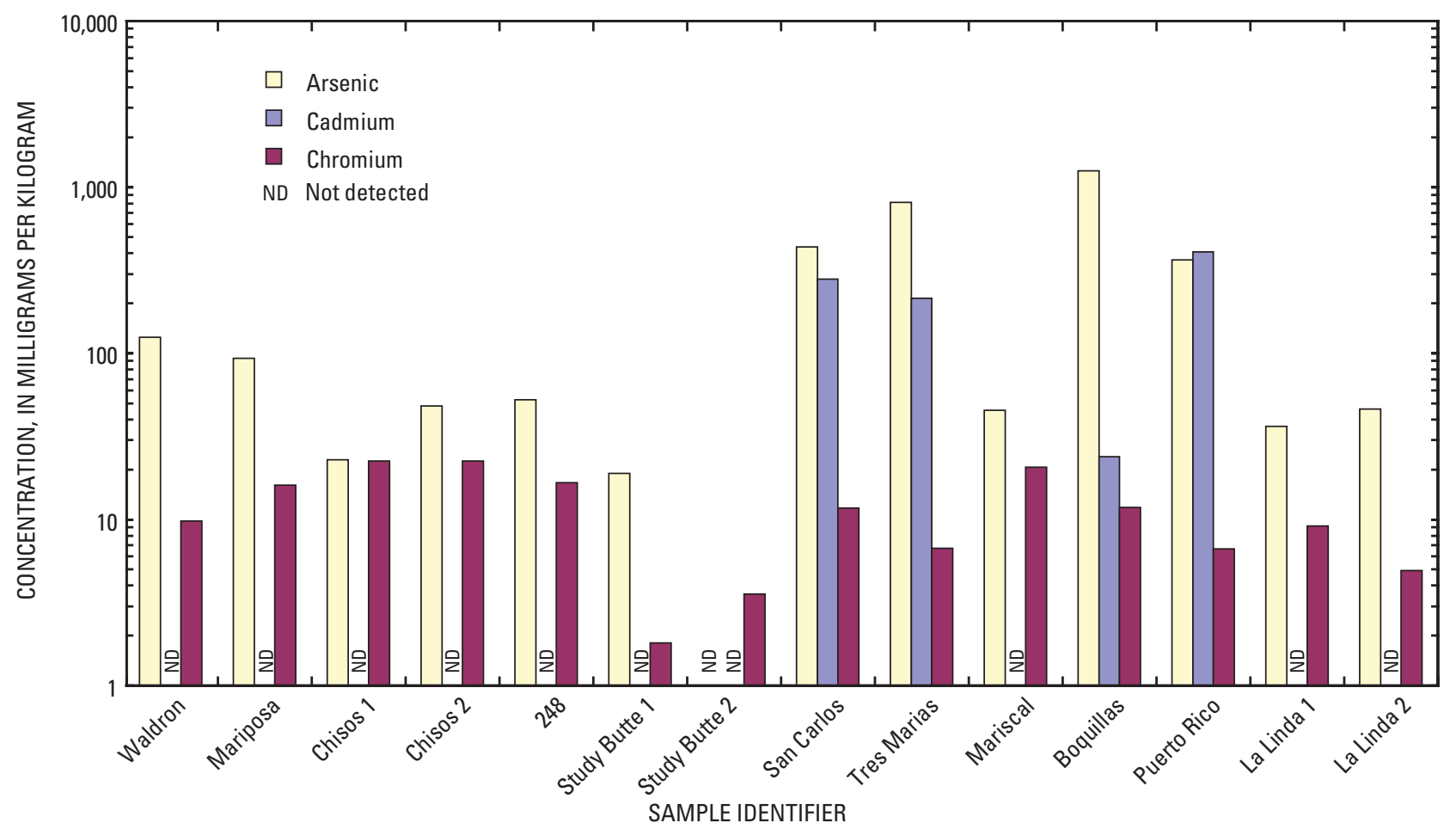

Figure 20. Detectable concentrations of arsenic, cadmium, and chromium in mine-tailing samples collected August 5-15, 2002, from abandoned mine and mine processing sites (downstream order) in the Big Bend area of the United States and Mexico.

Mariscal sample in BBNP (fig. 20). None of the samples exceeded the TCEQ sediment screening level for chromium of $111 \mathrm{mg} / \mathrm{kg}$ (table 3).

Copper concentrations were detected in 13 of 14 minetailing samples and ranged from 4 to $2,310 \mathrm{mg} / \mathrm{kg}$ (table 6). The highest copper concentrations were measured in Tres Marias (119 mg/kg), Boquillas (1,780 mg/kg), and Puerto Rico (2,310 mg/kg) mine-tailings samples (fig. 21; table 6). The samples from Boquillas and Puerto Rico Mines in the lower part of the study area exceeded the TCEQ sediment screening level for copper of $149 \mathrm{mg} / \mathrm{kg}$ (table 3).

Mercury concentrations were detected in all mine-tailing samples and varied widely, ranging from 0.08 to $966 \mathrm{mg} / \mathrm{kg}$ with a median of $120 \mathrm{mg} / \mathrm{kg}$. The highest mercury concentrations were from the Mariposa, Two-Forty-Eight, and Study Butte 2 samples collected in the Terlingua mining district in Texas and from the Tres Marias sample in Chihuahua. Mercury concentrations in samples from 10 of 14 sites exceeded the TCEQ sediment screening level for mercury of $1.06 \mathrm{mg} / \mathrm{kg}$ (table 3).

Nickel was detected in nine of 14 mine-tailing samples, with concentrations ranging from 3.5 to $39 \mathrm{mg} / \mathrm{kg}$. The highest concentrations were measured in the Chisos and Mariscal samples (fig. 21). All nickel concentrations were less than the TCEQ sediment screening level for nickel of $48.6 \mathrm{mg} / \mathrm{kg}$.

Lead was detected in seven of 14 mine-tailing samples. The detectable lead concentrations ranged from 7 to 67,900 $\mathrm{mg} / \mathrm{kg}$ (fig. 22; table 6). The highest concentrations were measured in the Boquillas, Puerto Rico, San Carlos, and Tres Marias samples, as might be expected because the tailings are from lead mines. The concentrations at these sites greatly exceeded the TCEQ sediment screening level for lead of $128 \mathrm{mg} / \mathrm{kg}$ (table 3 ).

The manganese concentration ranged from 120 to 18,600 $\mathrm{mg} / \mathrm{kg}$. Concentrations in most samples ranged from 120 to $440 \mathrm{mg} / \mathrm{kg}$, but concentrations in the Boquillas, Puerto Rico, and San Carlos samples were $700 \mathrm{mg} / \mathrm{kg}$ or greater. The highest concentration was measured in the San Carlos sample.

Silver was detected in the San Carlos, Boquillas, and Puerto Rico samples. All detectable concentrations exceeded the TCEQ sediment screening level for silver of $2.2 \mathrm{mg} / \mathrm{kg}$ (table 3).

Zinc was detected in all mine-tailing samples and ranged in concentration from 28 to $90,400 \mathrm{mg} / \mathrm{kg}$ (fig. 22; table 6). Concentrations in 10 of 14 samples were $181 \mathrm{mg} / \mathrm{kg}$ or less. Concentrations in the four remaining samples (San Carlos, Tres Marias, Boquillas, and Puerto Rico sites) ranged from 15,000 to $90,400 \mathrm{mg} / \mathrm{kg}$, greatly exceeding the TCEQ screening criterion for zinc of $459 \mathrm{mg} / \mathrm{kg}$ (table 3 ).

There were between 14 and 21 detectable concentrations of the 25 major and trace elements that were analyzed for in each of the mine-tailing samples (table 6). The most detections were in the samples from Boquillas Mine (21 of 25) and Study Butte Mine site 1 (20 of 25). The highest concentrations of calcium, beryllium, and molybdenum were in the sample from La Linda Mine/processing plant 2. The highest 


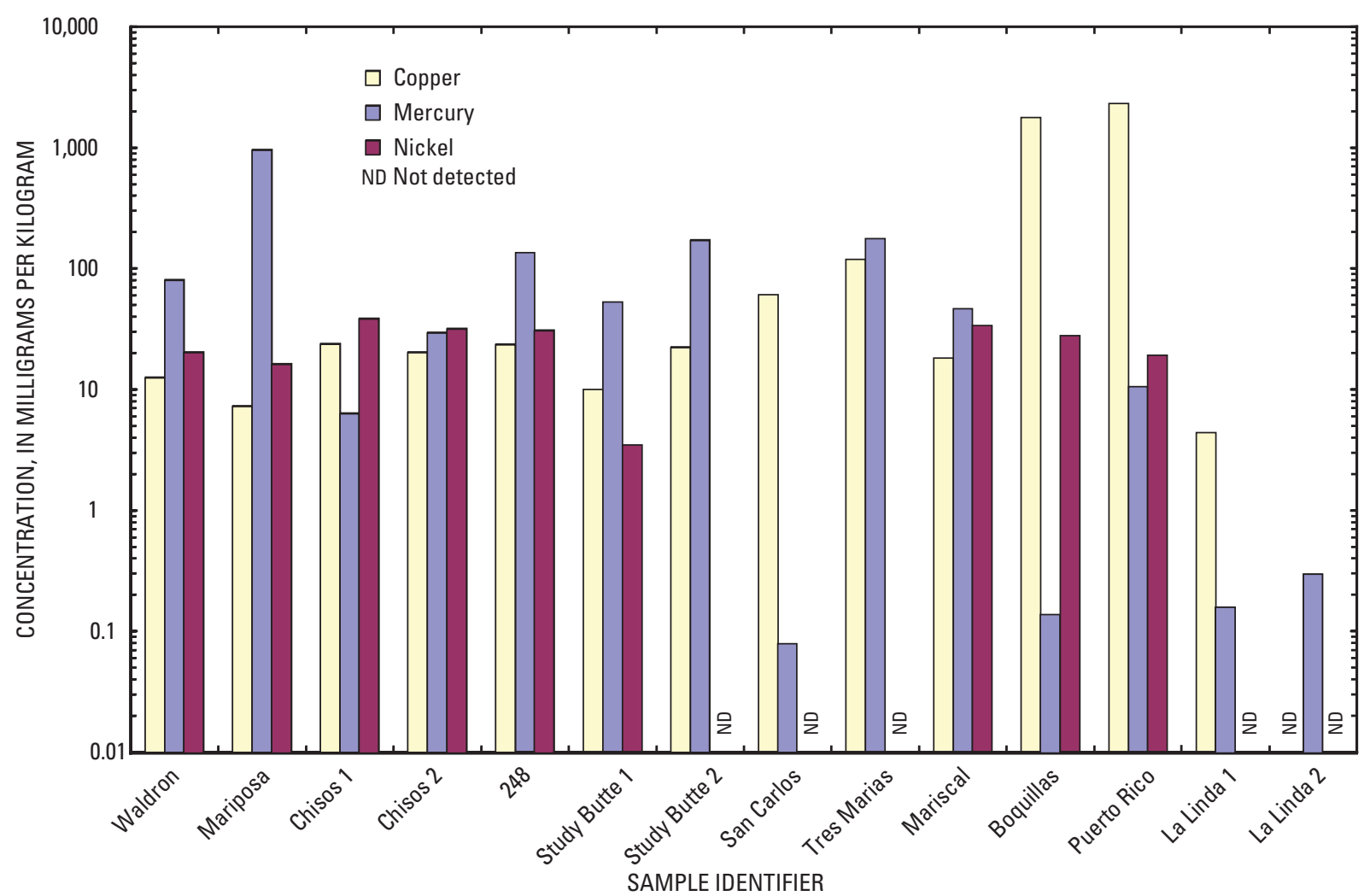

Figure 21. Detectable concentrations of copper, mercury, and nickel in mine-tailing samples collected August 5-15, 2002, from abandoned mine and mine processing sites (downstream order) in the Big Bend area of the United States and Mexico.

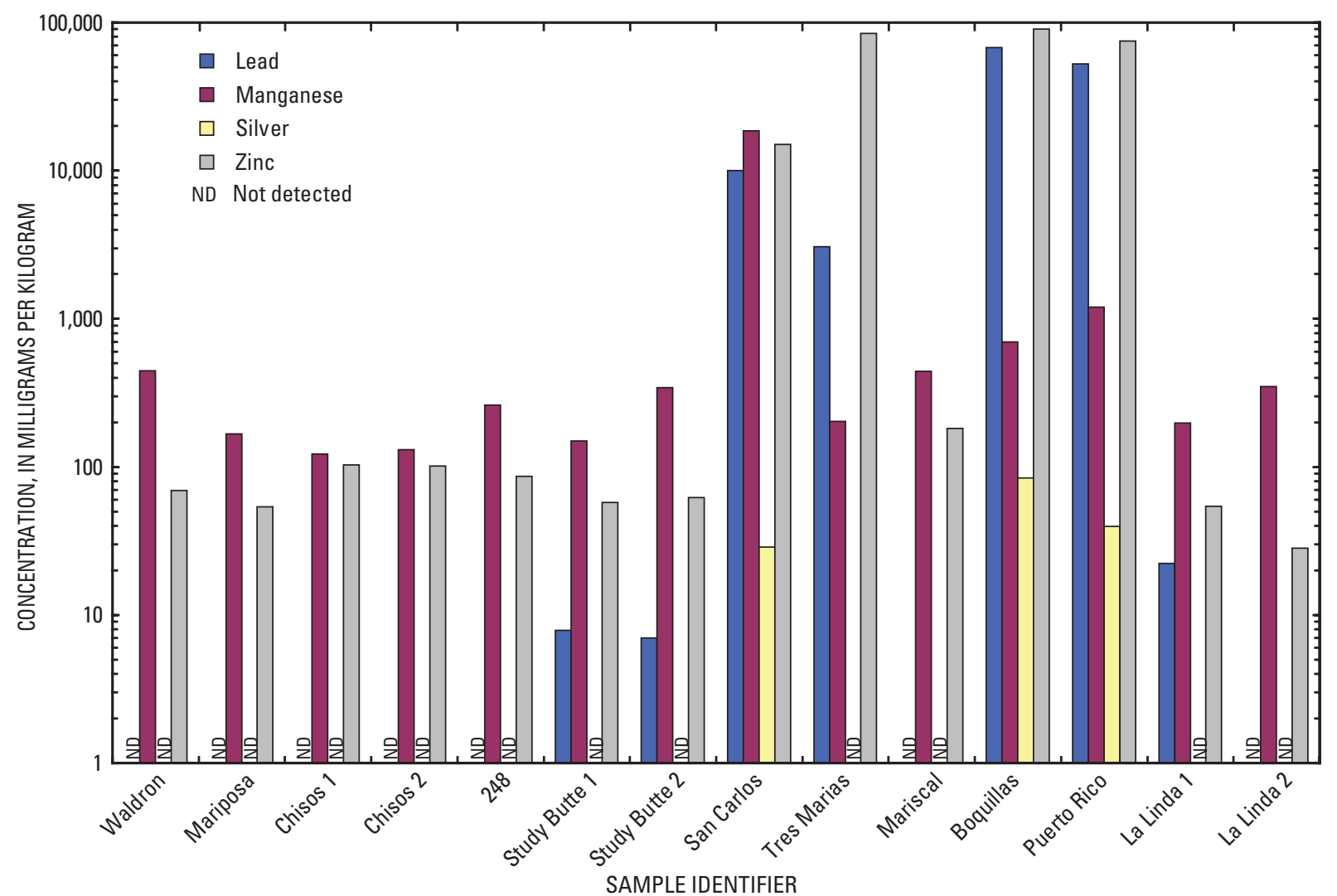

Figure 22. Detectable concentrations of lead, manganese, silver, and zinc in mine-tailing samples collected August 5-15, 2002, from abandoned mine and mine processing sites (downstream order) in the Big Bend area of the United States and Mexico. 
concentrations of potassium, arsenic, lead, silver, and zinc were in the sample from Boquillas Mine. The highest concentrations of magnesium, antimony, cobalt, iron, and manganese were in the sample from San Carlos Mine. The highest aluminum and nickel concentrations were in the sample from Chisos/Rainbow Mine 2. The highest cadmium and copper concentrations were in the sample from Puerto Rico Mine; the highest mercury concentration was from Mariposa Mine; the highest sodium concentration was from Two-Forty-Eight Mine; and the highest barium concentration was from Waldron Mine.

Trace element concentrations generally were higher in streambed-sediment samples from San Carlos Creek than from any other main-stem or tributary site. Unlike the other mine sites, the tailings from the San Carlos Mine lie across the headwaters of San Carlos Creek, dominating the area. The tailings at San Carlos Mine generally were finer and less consolidated than those at the other mine sites. These characteristics likely facilitate the transport of mine tailings into San Carlos Creek. Few of the other mine sites were as close to the perennial streams that were sampled during this study. Other mine sites generally were adjacent to ephemeral streams that dry quickly following storms. San Carlos Creek is one of the few perennial tributaries in the area. Mine tailings also were visible in San Carlos Creek downstream from the tailings; they appear to be a dominant part of the streambed sediment. These factors probably account for the appreciably higher trace element concentrations in the San Carlos Creek streambed-sediment sample compared to concentrations in sediment samples from other sites. The relative concentrations of arsenic, cadmium, lead, manganese, silver, and zinc in the streambed-sediment sample from San Carlos Creek are similar to those in the mine-tailing sample from San Carlos Mine. To a lesser extent, this relation also applies to relative concentrations of those trace elements in the sediment sample from Rough Run Draw and in tailings samples from Study Butte Mine.

\section{Leaching Potential}

The potential for leaching of antimony, arsenic, barium, beryllium, chromium, nickel, selenium, and silver from the mine tailings was less than the TCLP screening limit (table 3) for all samples collected during this study (table 7). The only trace elements with a leaching potential equal to or greater than the TCLP limit were cadmium and lead. The TCLP cadmium concentration for San Carlos Mine was $6.50 \mathrm{mg} / \mathrm{L}$, exceeding the TCLP limit for cadmium of $1.0 \mathrm{mg} / \mathrm{L}$; and the TCLP cadmium concentration for Tres Marias Mine was 1.00 $\mathrm{mg} / \mathrm{L}$, which equaled the TCLP screening limit. TCLP lead concentrations were detected in four of 14 samples; the highest TCLP lead concentrations were in tailings from San Carlos Mine (15.5 mg/L) and Boquillas Mine/processing area (120 $\mathrm{mg} / \mathrm{L})$. Both concentrations exceeded the TCLP screening limit for lead of $5 \mathrm{mg} / \mathrm{L}$.

Overall, the relatively low TCLP concentrations for most trace elements indicate that the potential for leaching because of weathering and other climatic effects is minimal. The higher leaching potentials for cadmium and lead might be the result of more recent mine activity or the volume of mine tailings that remain at some sites. Many of the mines in the upper part of the study area in the United States have been inactive for several decades.

\section{Summary}

This report characterizes the quality of water, streambed sediment, and mine tailings in the Rio Grande/Río Bravo (RG/ $\mathrm{RB}$ ) Basin in the Big Bend study area of Texas in the United States and Chihuahua and Coahuila in Mexico. Mines in the area were operated from the late 1800s through at least the late 1970s. Mercury mines and mine processing areas that were sampled include the Waldron Mine, Mariposa Mine, Chisos/ Rainbow Mine, Two-Forty-Eight Mine, and Study Butte Mine in the Terlingua mining district and Mariscal Mine in Big Bend National Park in the United States. The fluorite, germanium, iron, lead, silver, and zinc mines that were sampled in Mexico include La Esperanza (San Carlos) Mine, Tres Marias Mine, Boquillas Mine/processing area, Puerto Rico Mine, and La Linda Mine/processing area.

The U.S. Geological Survey (USGS), in cooperation with the International Boundary and Water Commission-U.S. and Mexican Sections, the National Park Service, the Texas Commission on Environmental Quality, the Secretaría de Medio Ambiente y Recursos Naturales in Mexico, the Área de Protección de Flora y Fauna Cañón de Santa Elena in Mexico, and the Área de Protección de Flora y Fauna Maderas del Carmen in Mexico, collected water-quality, bed-sediment, and minetailing samples during August 2002 for a study to determine whether trace elements from abandoned mines in the area in and around Big Bend National Park have adversely affected water and sediment quality in the RG/RB Basin. Samples were collected from eight sites on the main stem of the RG/RB, four RG/RB tributaries downstream from abandoned mines or mine-tailing sites, and 11 mine-tailing sites, one of which also is a specific-source site (holding tank). The water-quality samples collected at the $12 \mathrm{RG} / \mathrm{RB}$ main-stem and tributary sites were analyzed for selected constituents including major ions; dissolved solids, total suspended solids, and volatile suspended solids; nutrients; and trace elements. Field properties also were measured- $-\mathrm{pH}$, specific conductance, temperature, dissolved oxygen, and alkalinity. The water-quality results were compared to the Texas Surface Water Quality Standards (TSWQS) written by the Texas Commission on Environmental Quality (TCEQ) to determine whether concentrations meet standards for human health and recreation uses, and also for the protection of aquatic life.

Calcium concentrations can be a measure of the capacity of the river system to buffer acidic mine drainage. The lowest calcium concentrations were measured in samples from the tributary sites, and the highest calcium concentrations were measured in samples from main-stem sites from Santa 
Elena Crossing downstream to La Linda. The higher calcium concentrations might be related to ground-water inflow from perennial springs that contribute ground water to base flow of the river.

In general, relatively high sulfate concentrations were in the upper part of the study area from the Lajitas to the Woodson's sites, with the highest sulfate concentrations from tributaries draining the Terlingua mining district. The sample from the Rough Run Draw site was the only one in which the sulfate concentration exceeded the TSWQS general-use protection criterion of $570 \mathrm{mg} / \mathrm{L}$. The lowest sulfate concentrations were in samples from the spring-fed San Carlos Creek and Arroyo del Fortino sites in Mexico. All chloride concentrations were less than the TSWQS general-use protection criterion.

The water in the RG/RB and its tributaries was fresh to slightly saline. The higher dissolved solids concentrations (slightly saline) were from the Lajitas, Rough Run Draw, and Terlingua Creek sites in the upper part of the study area downstream from the Terlingua mining district. The lowest dissolved solids concentration (the freshest water) was at the Santa Elena Crossing site and could indicate a freshwater source, possibly ground-water seepage from springs into the main-stem RG/RB in this area, that is diluting dissolved solids concentrations. Dissolved solids concentrations of all samples were less than the TSWQS criterion of 1,500 mg/L. Total suspended solids concentrations were highest in samples collected from the main-stem RG/RB sites Solis, La Clocha, and Boquillas Canyon.

The pHs of all samples were moderate (relatively neutral) and met the TSWQS general-use protection criterion TCEQ has established for segment 2306 of the RG/RB. The moderate $\mathrm{pHs}$ indicate that waters in the RG/RB and its tributaries are well-mixed, diluted, and buffered with respect to the solubility of trace elements from mining areas.

Aluminum, barium, copper, mercury, nickel, selenium, and zinc were detected in water samples for which each was analyzed. Cadmium, chromium, and lead were detected in samples less frequently, and silver was not detected in any of the samples. Cadmium was detected at San Carlos Creek and Arroyo del Fortino; chromium was detected at Lajitas, Terlingua Creek, and Arroyo del Fortino. Lead was detected in the Lajitas, Santa Elena Canyon, San Carlos Creek, Santa Elena Crossing, Boquillas Canyon, and Arroyo del Fortino. None of the sample concentrations for aluminum, cadmium, chromium, nickel, selenium, and zinc exceeded the TSWQS criteria for aquatic life-use protection or human health. The lead concentration in the San Carlos Creek sample exceeded the TSWQS chronic criterion for the protection of aquatic life and the human health criterion for fish consumption. The mercury concentration in water samples from all but two tributary sites exceeded the TSWQS criterion for human health (fish consumption use). Relatively high mercury concentrations are distributed throughout the study area, which might indicate sources in addition to abandoned mining areas; a previous study indicated atmospheric deposition as a potential source.
Streambed-sediment samples were collected from 12 sites and analyzed for 44 major and trace elements. Streambed sediment is assessed by the TCEQ in support of aquatic life-use protection. Streambed-sediment trace element analytical results were compared to TCEQ sediment screening levels. In general, the trace elements that were detected in the streambed-sediment samples were low in concentration, interpreted as consistent with background concentrations and not the result of point-source contamination. Trace-element concentrations at two sites, however, were elevated compared to TCEQ screening levels or relative to concentrations at other sites. Concentrations of antimony, arsenic, cadmium, lead, silver, and zinc in the San Carlos Creek sample downstream from the San Carlos Mine exceeded the TCEQ screening levels for sediment. The sample from Rough Run Draw, downstream from the Study Butte Mine, also showed higher than background concentrations of arsenic, cadmium, and lead, but these concentrations were much lower than those in the San Carlos Creek sample and did not exceed TCEQ screening levels. Elevated concentrations of multiple trace elements in samples from the San Carlos Creek and Rough Run Draw sites indicate that San Carlos Creek, and probably Rough Run Draw, have been adversely affected by mining activities.

Fourteen mine-tailing samples from 11 mines in the United States and Mexico were analyzed for 25 major and trace elements. All 25 trace elements except selenium and thallium were detected in one or more of the mine-tailing samples. Concentrations of the trace elements for which TCEQ has screening levels were compared to those levels. Antimony concentrations in tailings at the Waldron Mine, San Carlos Mine, and Boquillas Mine exceeded the TCEQ sediment screening level for antimony. Arsenic was detected in samples from all tailings sites except the Study Butte 2 site. Detected concentrations in all but two samples exceeded the TCEQ sediment screening level for arsenic. The highest arsenic concentrations were measured in the Boquillas tailings. Cadmium was detected at four sites, with the highest concentrations at the San Carlos, Tres Marias, and Puerto Rico sites. Cadmium concentrations at four sites exceeded the TCEQ sediment screening level for cadmium. Chromium was detected in all samples at concentrations less than the TCEQ sediment screening level. Copper was detected in 13 of 14 samples, and concentrations in two of the samples (Boquillas and Puerto Rico) exceeded the TCEQ sediment screening level. Lead was detected in seven of 14 mine-tailing samples. The highest lead concentrations were measured in the Boquillas, Puerto Rico, San Carlos, and Tres Marias samples, as might be expected because the tailings are from lead mines. The concentrations at these sites greatly exceeded the TCEQ sediment screening level for lead. Mercury was detected in all mine-tailing samples and concentrations exceeded the TCEQ sediment screening level in 10 of 14 samples. The highest mercury concentrations were measured in the Mariposa, Tres Marias, Study Butte 2, and Two-Forty-Eight tailings samples. Nickel was detected in nine of 14 samples, and all concentrations were less than the TCEQ screening level. 
Silver was detected in the San Carlos, Boquillas, and Puerto Rico samples; all detected concentrations exceeded the TCEQ screening level. Zinc was detected in all mine-tailing samples, and the zinc concentrations greatly exceeded the TCEQ screening level in the Boquillas, Tres Marias, Puerto Rico, and San Carlos samples.

The Toxicity Characteristic Leaching Procedure (TCLP) was applied to 14 samples from 11 abandoned mine and mine processing sites to determine the leaching potential of antimony, arsenic, barium, beryllium, cadmium, chromium, lead, nickel, selenium, and silver. In general, results of the analyses indicate that the leaching potential (concentration) for most trace elements was less than the TCLP limit. The TCLP yielded detectable concentrations for at least one constituent at each mine. The highest TCLP concentrations were for cadmium in samples from San Carlos and Tres Marias Mines and for lead in samples from Boquillas and San Carlos Mines. Cadmium and lead TCLP concentrations in the San Carlos Mine tailings and the lead TCLP concentration in the Boquillas Mine tailings equaled or exceeded the TCLP limit.

\section{References}

Albion Environmental, 2003a, Ace Technology/IBWC Big Bend clean metals and mercury study_-Final aqueous mercury data for Big Bend samples collected 6-9 August 2002: Private consultant analytical data report narrative to International Boundary and Water Commission, January 17, 2003, 6 p.

Albion Environmental, 2003b, Ace Technology/IBWC Big Bend clean metals and mercury monitoring study-Final total recoverable aqueous selenium data for samples collected 6-9 August 2002: Private consultant analytical data report narrative to International Boundary and Water Commission, March 24, 2003, 2 p.

Albion Environmental, 2003c, Ace Technology/IBWC Big Bend clean metals and mercury study-Final aqueous dissolved trace metals data for samples collected 6-9 August 2002: Private consultant analytical data report narrative to International Boundary and Water Commission, March 24, 2003, 2 p.

Arbogast, B.F., 1996, Analytical methods for the Mineral Resource Surveys Program: U.S. Geological Survey OpenFile Report 96-525, 248 p.

Bates, S.S., Tessier, A., Campbell, P.G., and Buffle, J., 1982, Zinc adsorption and transport by Chlamydomonas variabilis and Scenedesmus subspicatus (Chlorophyceae) grown in semicontinuous culture: Journal of Phycology, v. 18, p. 521-529.

Briggs, P.H., and Meier, A.L., 1999, The determination of forty two elements in geological materials by inductively coupled plasma-mass spectrometry: U.S. Geological Survey Open-File Report 99-166, 15 p.

Chester, J.W., 1965, Mercury potential in Texas-Chapter 10. Mercury in Texas: U.S. Bureau of Mines Information Circular 8252, p. 337-351.

Davis, J.R., 1980, Species composition and diversity of benthic macroinvertebrates in the upper Rio Grande, Texas: Southwestern Naturalist, v. 25, p. 137-150.

Environment, Health, and Safety Online, 2007, TCLP FAQS: accessed November 5, 2007, at http://www.ehso.com/ cssepa/TCLP.htm

Federal Register, 2007, Health-based limits for exclusion of waste-derived residues: Washington D.C., U.S. Government Printing Office, Code of Federal Regulations, Title 40, Part 266, Subpart O, Appendix VII.

Gray, J.E., Hines, M.E., and Biester, Harald, 2006, Mercury methylation influenced by areas of past mercury mining in the Terlingua district, Southwest Texas, USA: Applied Geochemistry, v. 21, p. 1,940-1,954.

Gutierrez, Melida, 2000, Trace element concentration patterns in sediments of the Lower Rio Conchos, Mexico: Water, Air, and Soil Pollution, v. 121, p. 259-270.

Helsel, D.R., and Hirsch, R.M., 1992, Statistical methods in water resources-Studies in environmental science 49: Amsterdam, Elsevier, 522 p.

Hem, J.D., 1992, Study and interpretation of chemical characteristics of natural water (3d ed.): U.S. Geological Survey Water-Supply Paper 2254, 263 p.

Horowitz, A.J., Elrick, K.A., and Smith, J.J., 2001, Annual suspended sediment and trace element fluxes in the Mississippi, Columbia, Colorado, and Rio Grande drainage basins, in Hooper, R.P., and Kelly, V.J., eds., Water quality of large U.S. rivers-Results from the U.S. Geological Survey's National Stream Quality Accounting Network: Hydrological Processes, v. 15, p. 1,169-1,207.

International Boundary and Water Commission, 1997, Second phase of the binational study regarding the presence of toxic substances in the Rio Grande/Río Bravo and its tributaries along the boundary portion between the United States and Mexico: International Boundary and Water Commission, v. II of II, Final Report, 138 p.

International Boundary and Water Commission, 2001, Rio Grande Basin Monitoring Program, Quality Assurance Project Plan (QAPP): United States Section, International Boundary and Water Commission, effective period December 1, 2001, to August 31, 2003, 79 p.

International Boundary and Water Commission, 2004, Third phase of the binational study regarding the presence of toxic substances in the Rio Grande/Río Bravo and its tributaries along the boundary portion between the United States and 
Mexico: International Boundary and Water Commission, 129 p.

International Boundary and Water Commission, 2007, Rio Grande historical mean daily discharge data, 08-3750.00: accessed November 1, 2007, at http://www.ibwc.state.gov/ Water_Data/histflol.htm

Lee, R.W., and Wilson, J.T., 1997, Trace elements and organic compounds associated with riverbed sediments in the Rio Grande/Río Bravo Basin, Mexico and Texas: U.S. Geological Survey Fact Sheet FS-098-97, 6 p.

Maxwell, R.A., and Dietrich, J.W., 1965, Geologic summary of the Big Bend region, in Geology of the Big Bend area, Texas: West Texas Geological Society Publication 65-51, p. 11-33.

Nash, J.T., 2003, Overview of mine drainage geochemistry at historical mines, Humboldt River Basin and adjacent mining areas, Nevada: U.S. Geological Survey Bulletin 2210-E, $27 \mathrm{p}$.

National Climatic Data Center, 2005, Climatological data annual summary-Texas for 2005: National Oceanic and Atmospheric Administration National Climatic Data Center annual report, v. 110 , no. 13,86 p.

National Parks Conservation Association, 2001, Group names annual list of America's Ten Most Endangered National Parks: April 4, 2001, press release, accessed at http://www.npca.org/media_center/press_releases/2001/ page-27598999.html

National Park Service, 2006, A lingering doubt-Peregrine falcons in Big Bend National Park: National Park Service, accessed June 26, 2007, at http://www.nps.gov/bibe/ naturescience/peregrine-doubt.htm

Nickerson, E.L., 2006, Description of piezometers and ground-water-quality characteristics at three new sites in the Lower Mesilla Valley, Texas, and New Mexico, 2003: U.S. Geological Survey Scientific Investigations Report 2005-5248, 27 p.

Pais, Istvan, and Jones, J.B., Jr., 1997, The handbook of trace elements: Boca Raton, Fla., St. Lucie Press, 223 p.

Ragsdale, K.B., 1976, Quicksilver-Terlingua \& the Chisos Mining Company: College Station, Tex., Texas A\&M University Press, 327 p.

Sharpe, R.D., 1980, Development of the mercury mining industry-Trans-Pecos Texas: Austin, University of Texas, Bureau of Economic Geology Mineral Resource Circular $64,32 \mathrm{p}$.

Shelton, L.R., and Capel, P.D., 1994, Guidelines for collecting and processing samples of stream and sediment for analysis of trace elements and organic contaminants for the National Water-Quality Assessment Program: U.S. Geological Survey Open-File Report 94-458, 25 p.
Swanson, 1995, Geo-Texas-A guide to the Earth sciences: College Station, Tex., Texas A\&M University Press, $208 \mathrm{p}$.

Taggart, J.E., Jr., ed., 2002, Analytical methods for chemical analysis of geologic and other materials, U.S. Geological Survey: U.S. Geological Survey Open-File Report 02-223 [variously paged].

Texas Commission on Environmental Quality, 2000, Texas Surface Water Quality Standards (effective August 17, 2000): Austin, Texas Commission on Environmental Quality, Texas Administrative Code, Chapter 307 [variously paged].

Texas Commission on Environmental Quality, 2003, Surface water quality monitoring procedures-Volume 1. Physical and chemical monitoring methods for water, sediment, and tissue: Austin, Texas Commission on Environmental Quality, RG-415 [variously paged].

Texas Commission on Environmental Quality, 2004, Texas water quality inventory and 303(d) list: Texas Commission on Environmental Quality, accessed April 6, 2007, at http://www.tceq.state.tx.us/compliance/monitoring/water/ quality/data/04twqi/twqi04.html

Texas Commission on Environmental Quality, 2006, Guidance for assessing and reporting surface water quality in Texas: Austin, Texas Commission on Environmental Quality [variously paged].

Texas Natural Resource Conservation Commission, 1994, Regional assessment of water quality in the Rio Grande Basin including the Pecos River, the Devils River, the Arroyo Colorado, and the Lower Laguna Madre: Austin, Texas Natural Resource Conservation Commission, Watershed Management Division, 337 p.

U.S. Environmental Protection Agency, 1992, Test methods for evaluating solid waste, physical/chemical methods: U.S. Environmental Protection Agency Report SW-846, accessed March 19, 2007, at http://www.epa.gov/sw-846/ sw846.htm

U.S. Environmental Protection Agency, 1995a, Method 1638-Determination of trace elements in ambient waters by inductively coupled plasma-mass spectrometry: U.S. Environmental Protection Agency, Office of Water, USEPA 821-R-95-031, 47 p.

U.S. Environmental Protection Agency, 1995b, Method 1669-Sampling ambient water for trace metals at USEPA water quality criteria levels: Washington, D.C., U.S. Environmental Protection Agency, Office of Water, USEPA 821-R-95-034, 36 p.

U.S. Environmental Protection Agency, 1996, Method 1632-Determination of inorganic arsenic in water by hydride generation flame atomic absorption: Washington, D.C., U.S. Environmental Protection Agency, Office of Water, $30 \mathrm{p}$. 
U.S. Environmental Protection Agency, 2001, Method 1631, revision $\mathrm{C}$-Mercury in water by oxidation, purge and trap, and cold vapor atomic fluorescence spectrometry: Washington, D.C., U.S. Environmental Protection Agency, Office of Water, USEPA 821-R-01-024, 31 p.

U.S. Environmental Protection Agency, 2002, Guidelines establishing test procedures for the analysis of pollutants under the Clean Water Act; National Primary Drinking Water Regulations; and National Secondary Drinking Water Regulations; methods update-Rules and regulations: U.S. Environmental Protection Agency, Federal Register Environmental Documents, v. 67, no. 205, p. 65,219-65,253.

U.S. Environmental Protection Agency, 2004, 2004 edition of the drinking water standards and health advisories: U.S. Environmental Protection Agency Report EPA 822-R-04-005, $12 \mathrm{p}$.
U.S. Geological Survey, 2006, National Stream Quality Accounting Network (NASQAN) published data-Rio Grande Basin: U.S. Geological Survey, accessed June 26, 2007, at http://water.usgs.gov/nasqan/data/finaldata/ riogrande.html

Van Metre, P.C., Mahler, B.J., and Callender, Edward, 1997, Water-quality trends in the Rio Grande/Río Bravo Basin using sediment cores from reservoirs: U.S. Geological Survey Fact Sheet 221-96, 8 p.

Winslow, A.G., and Kister, L.R., 1956, Saline-water resources of Texas: U.S. Geological Survey Water-Supply Paper 1365, $105 \mathrm{p}$.

Yates, R.G., and Thompson, G.A., 1959, Geology and quicksilver deposits of the Terlingua district, Texas: U.S. Geological Survey Professional Paper 312, $114 \mathrm{p}$. 


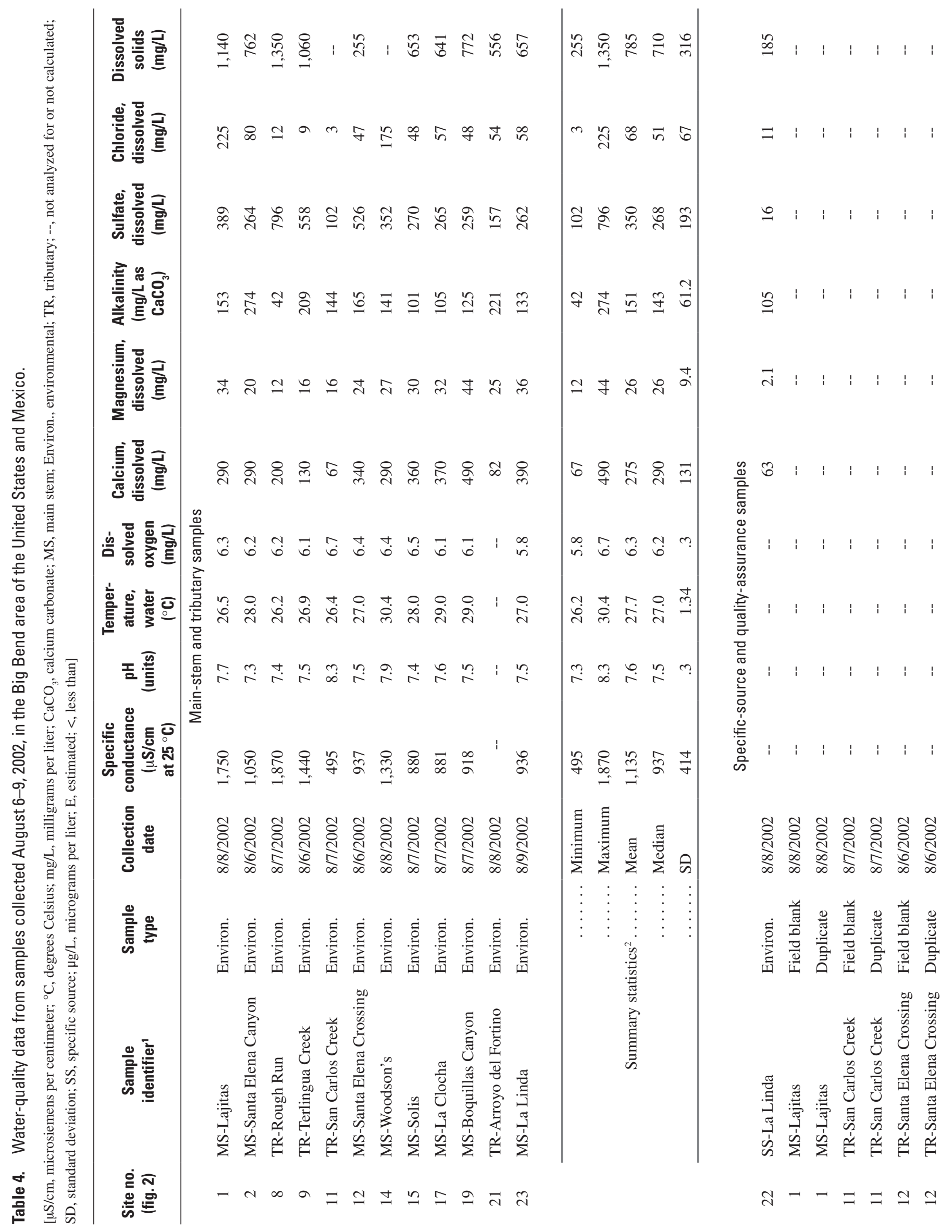




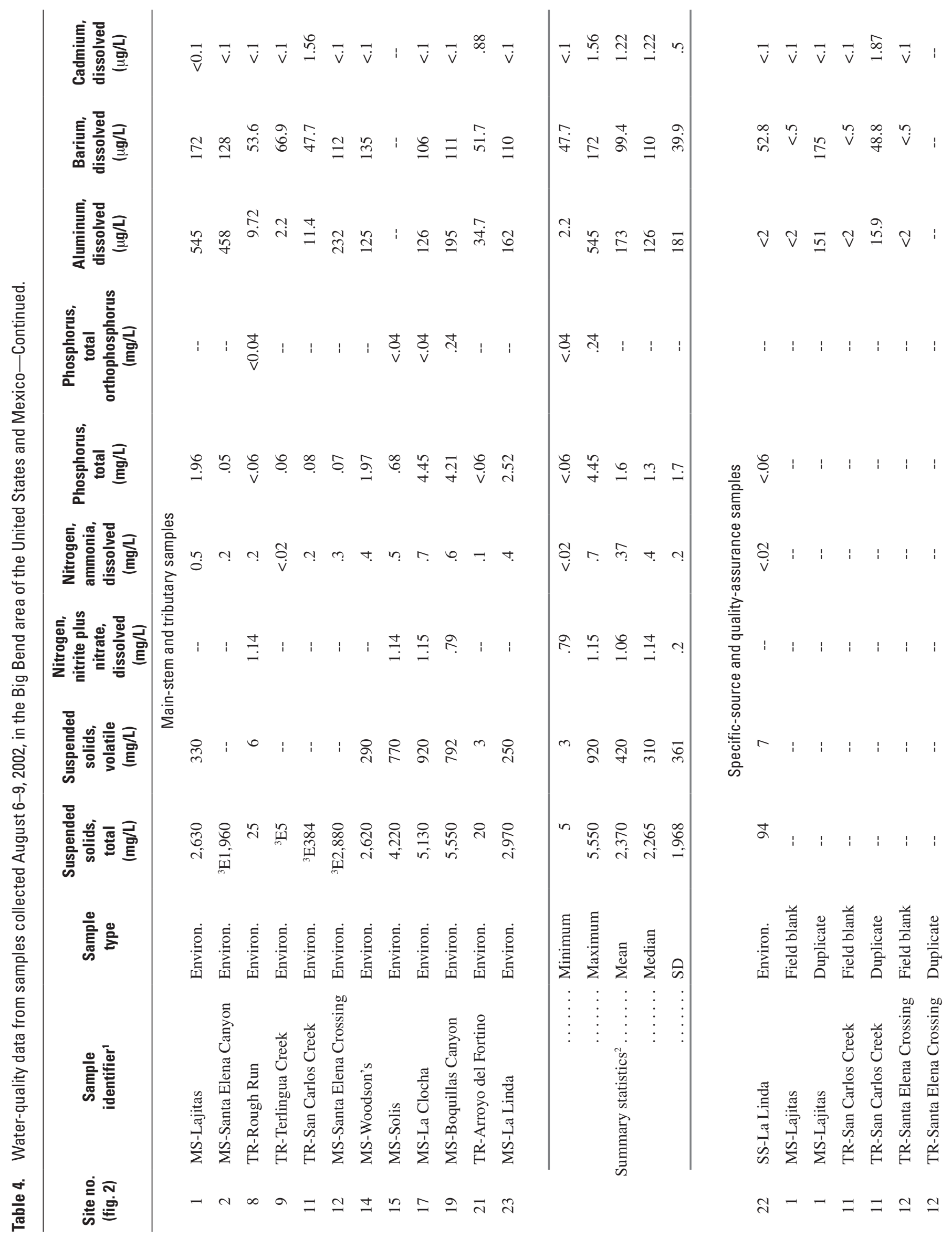




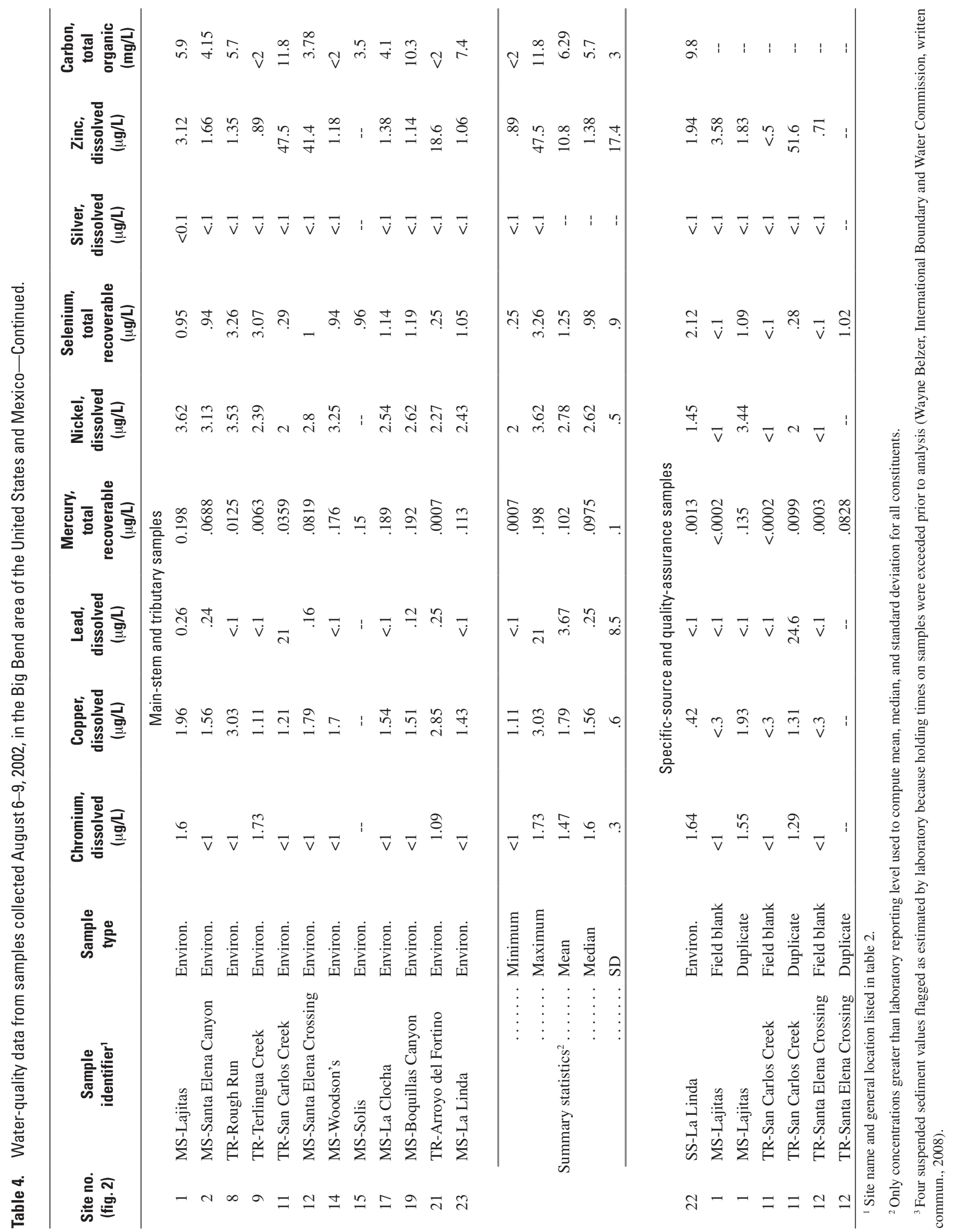


Table 5

39

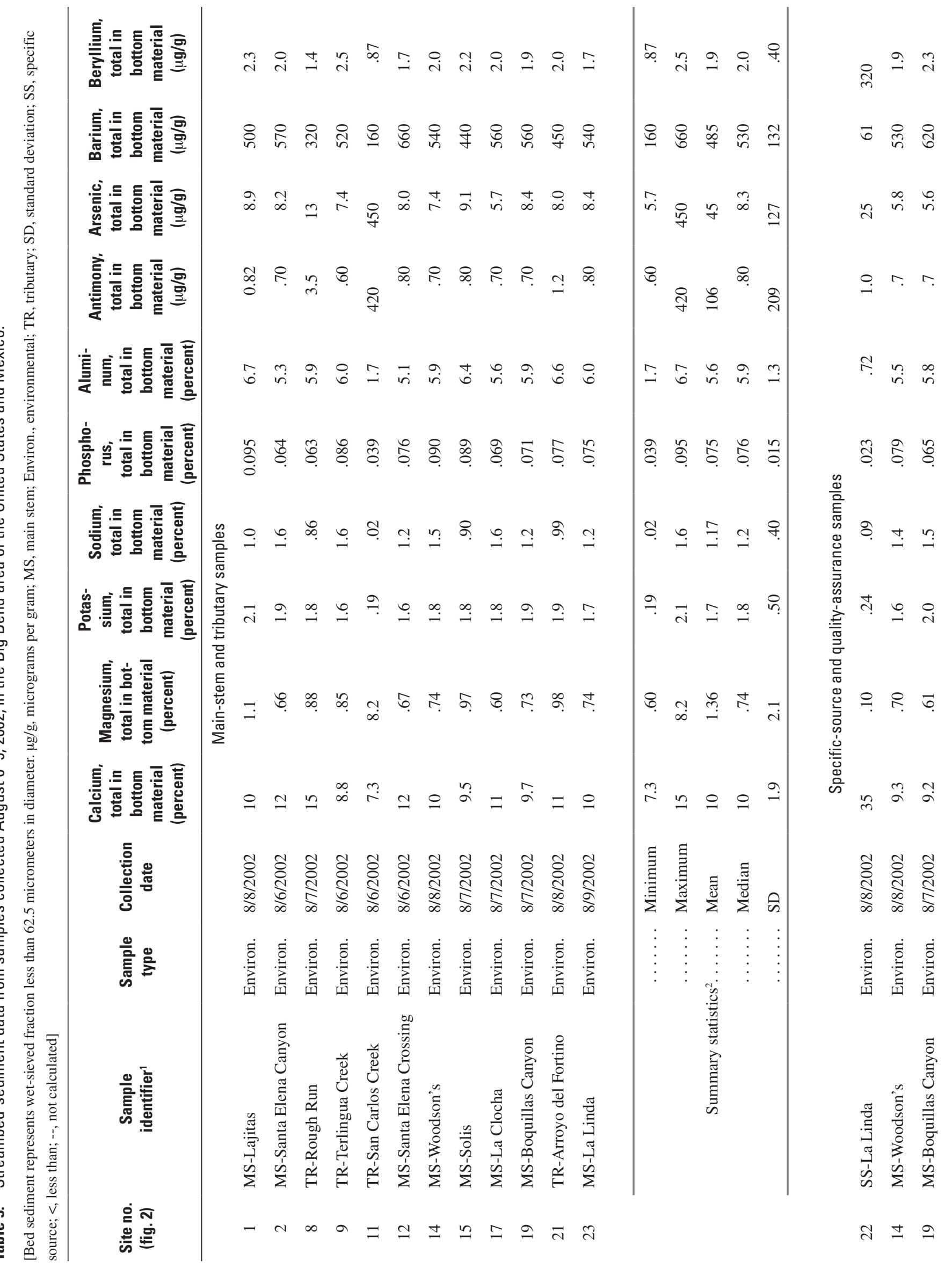




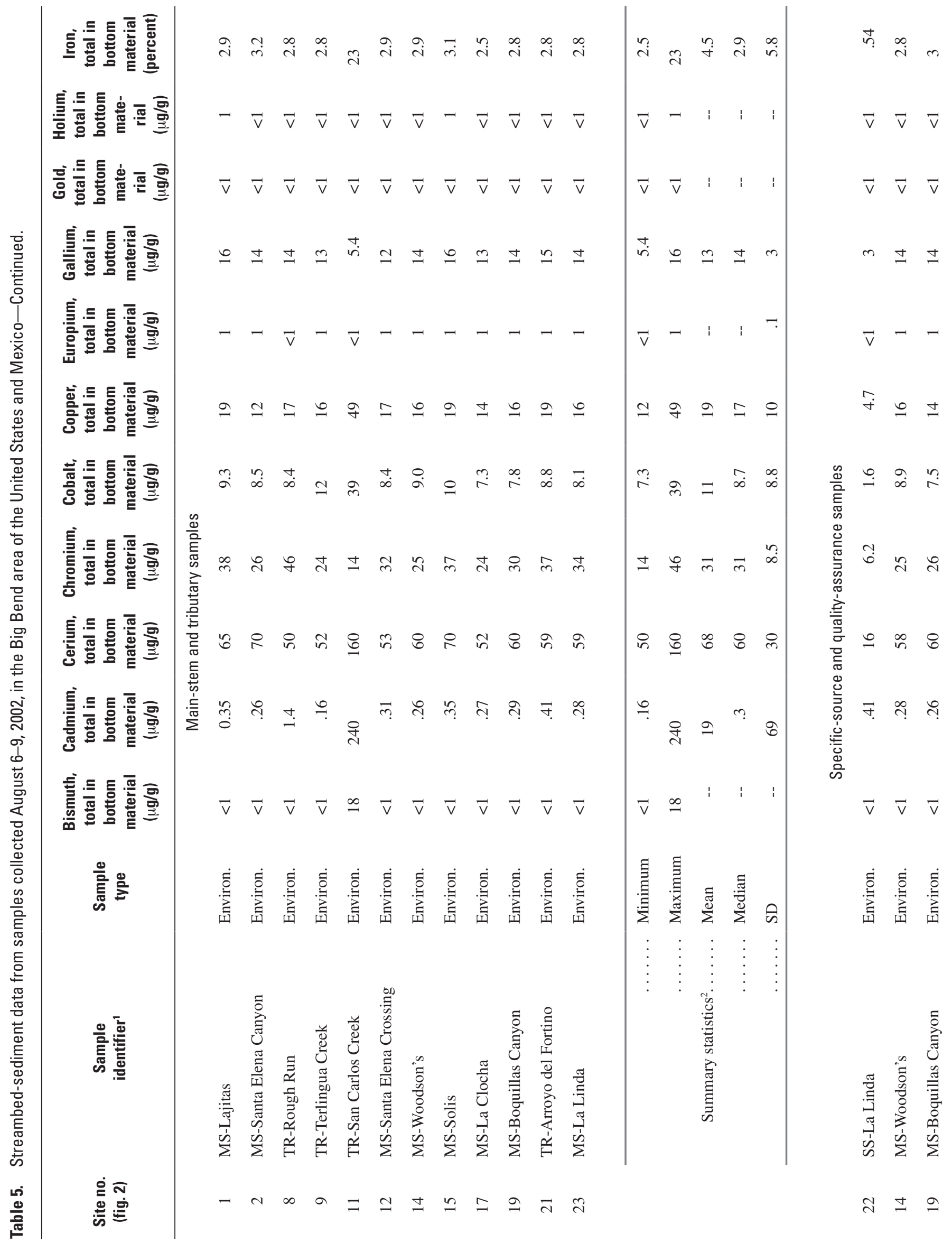


Table 5

41

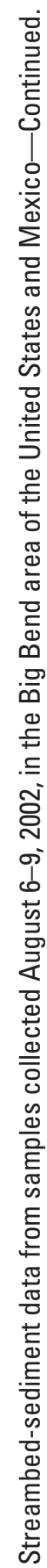

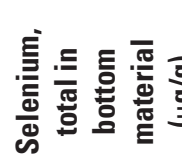

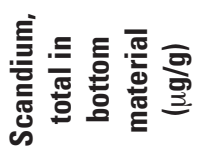

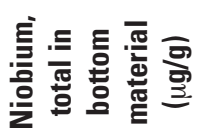

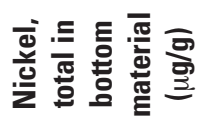

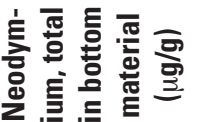

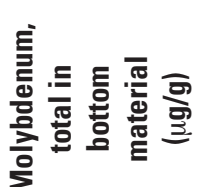

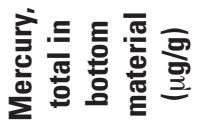

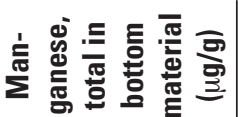

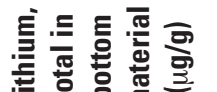

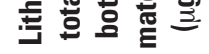

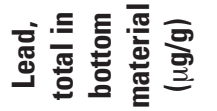

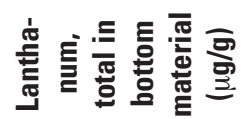

高

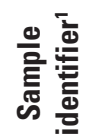

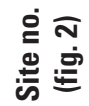

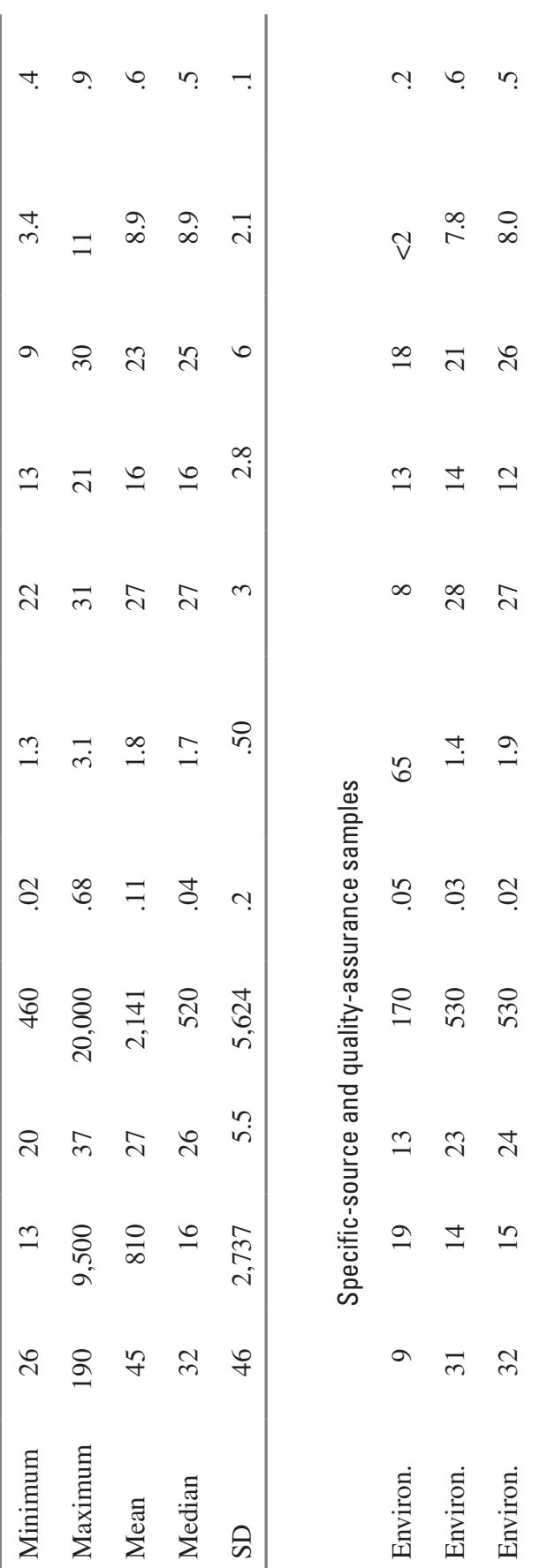

๕

政 $\sum$

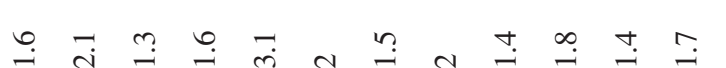

离 品

m

$\infty m a m$ m $m+r+0 a$

म

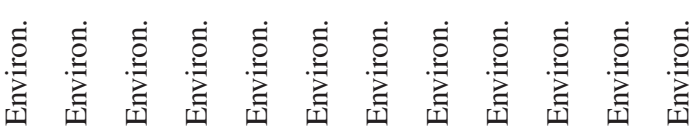

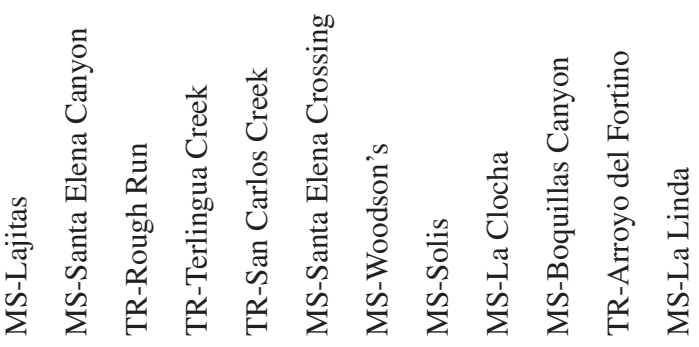

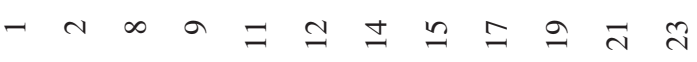
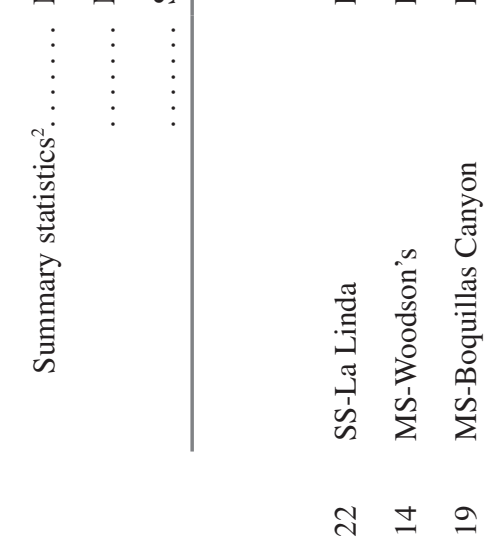


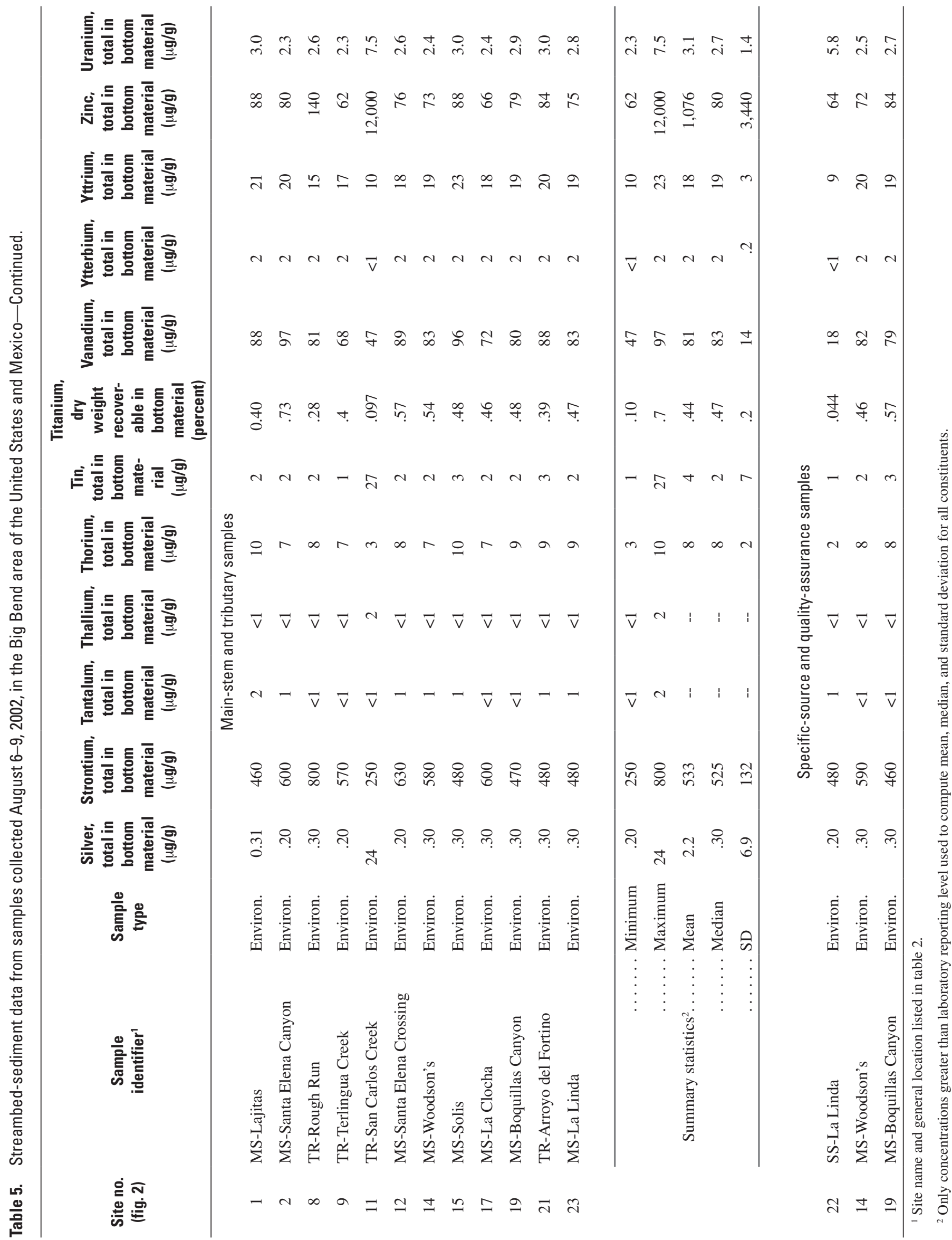




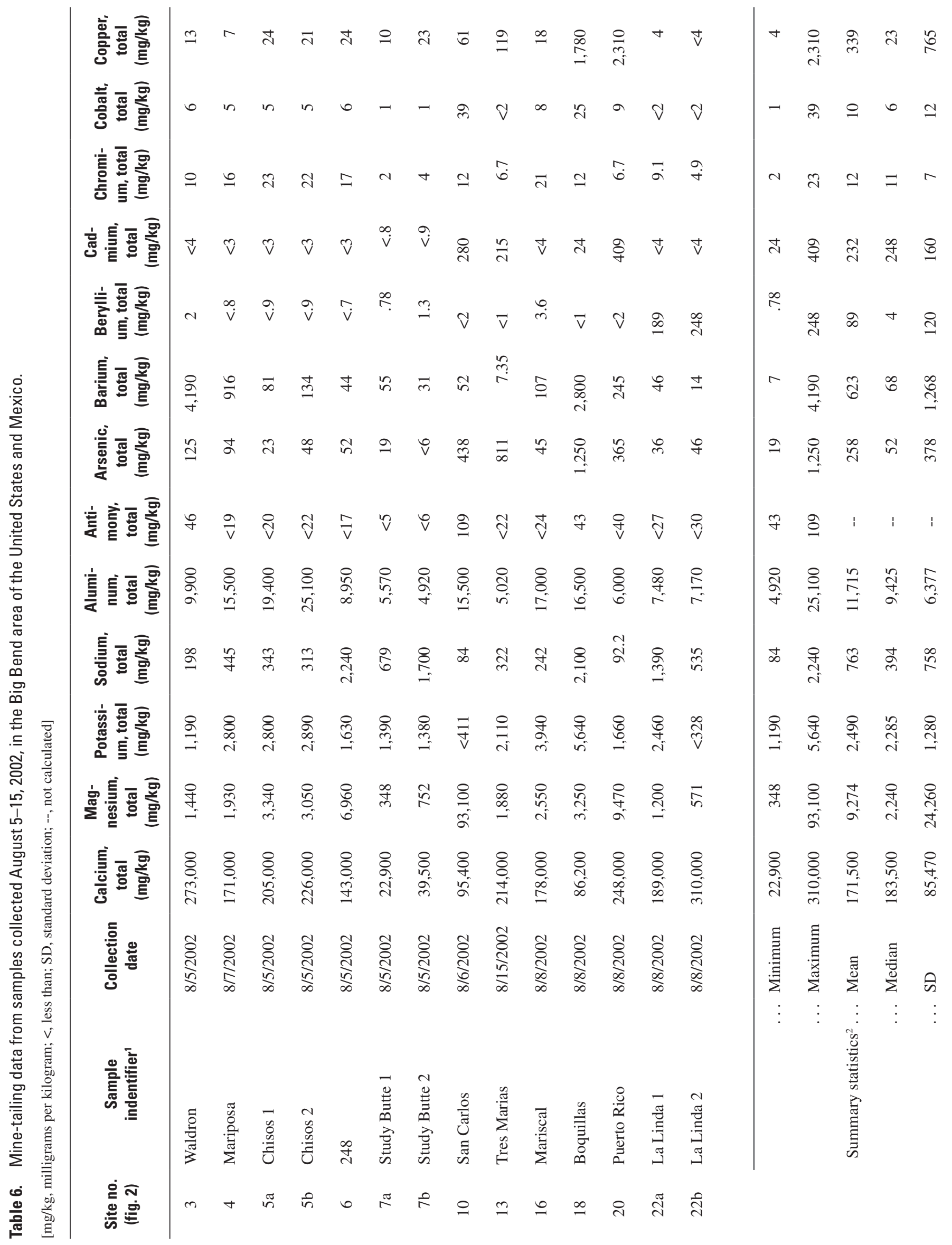




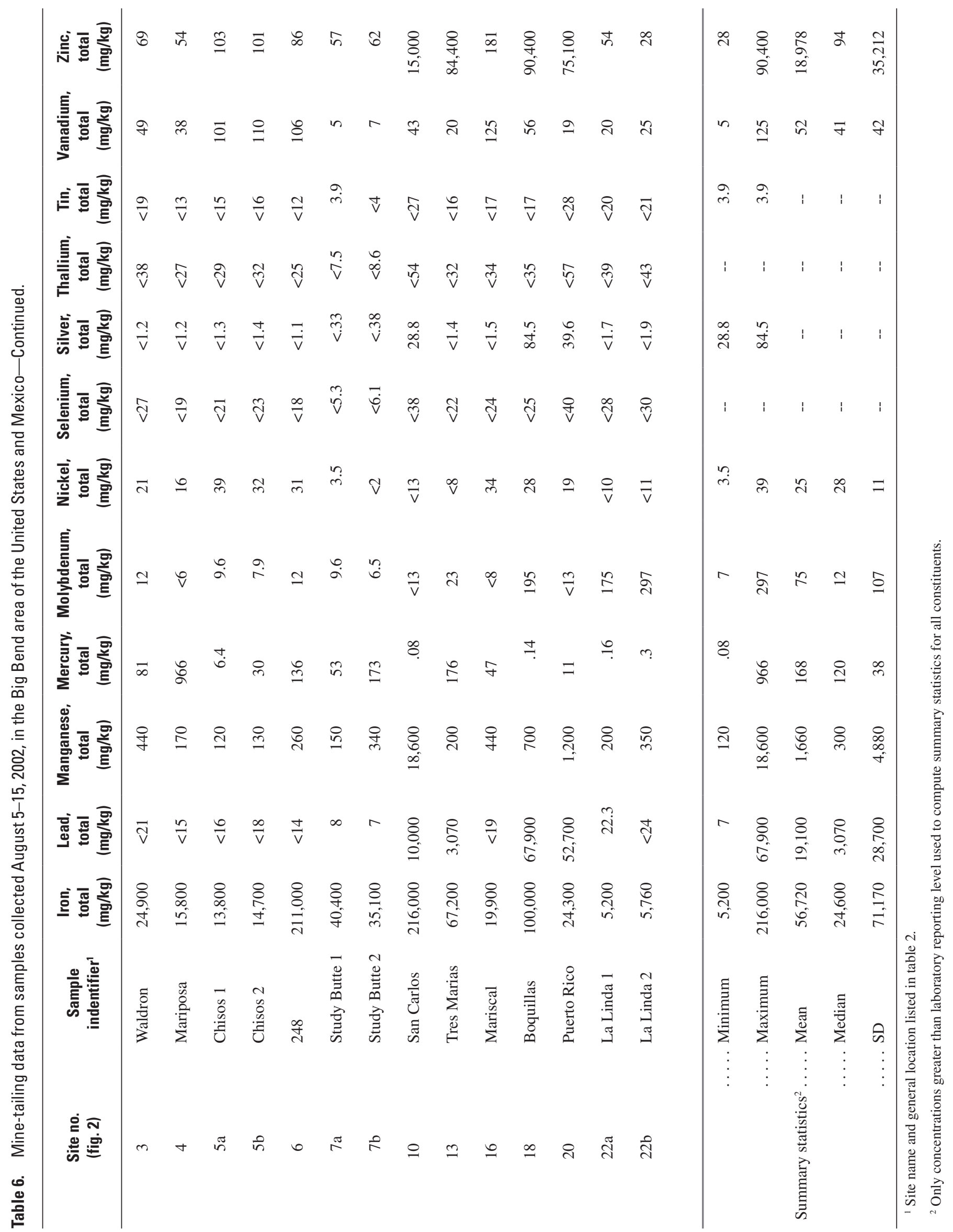




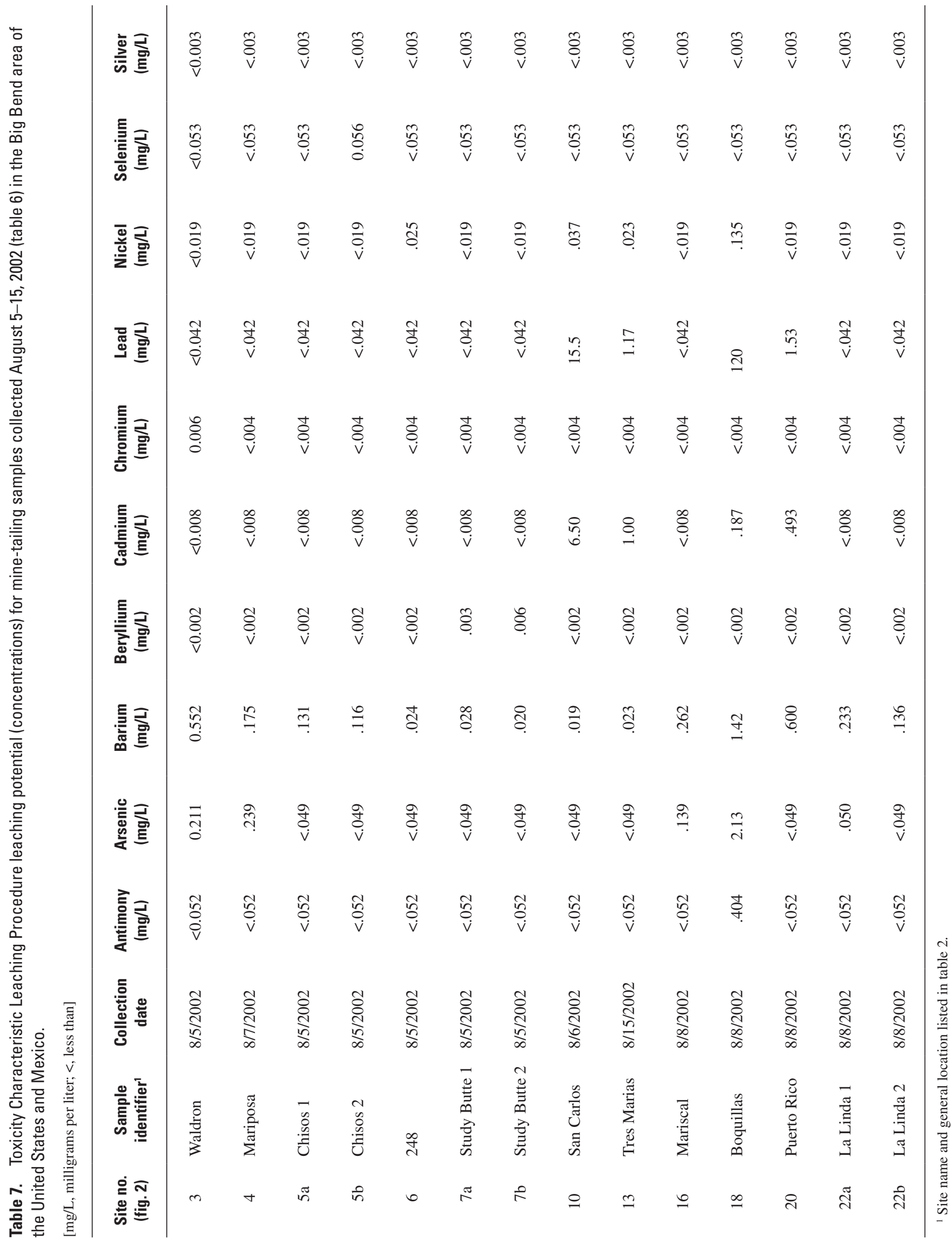


Publishing support provided by

Lafayette Publishing Service Center

Information regarding water resources in Texas is available at http://tx.usgs.gov/ 

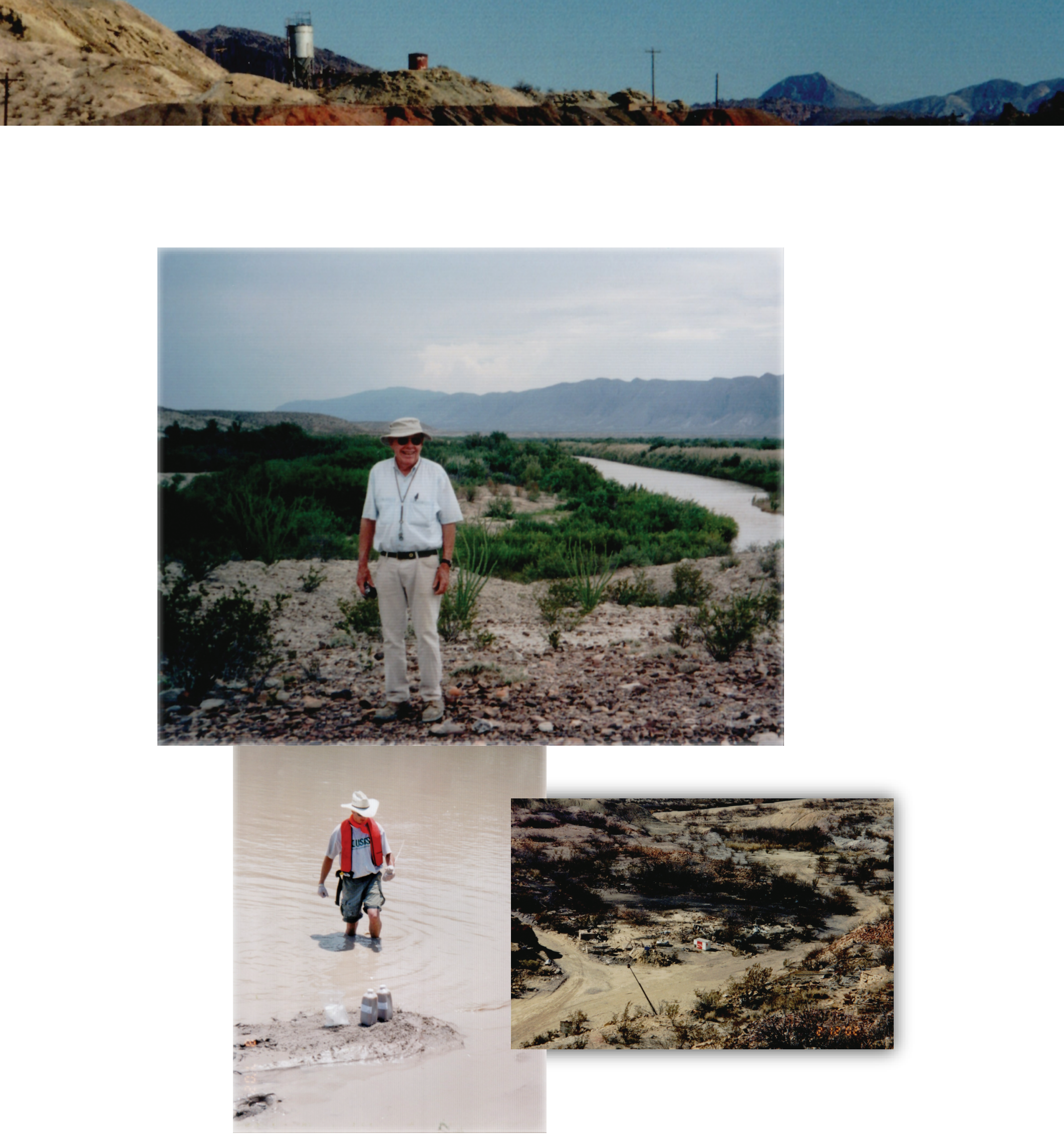